A Field Guide to the Identification of the Ordinary High Water Mark (OHWM) in the Arid West Region of the Western United States

A Delineation Manual

Robert W. Lichvar and Shawn M. McColley

August 2008

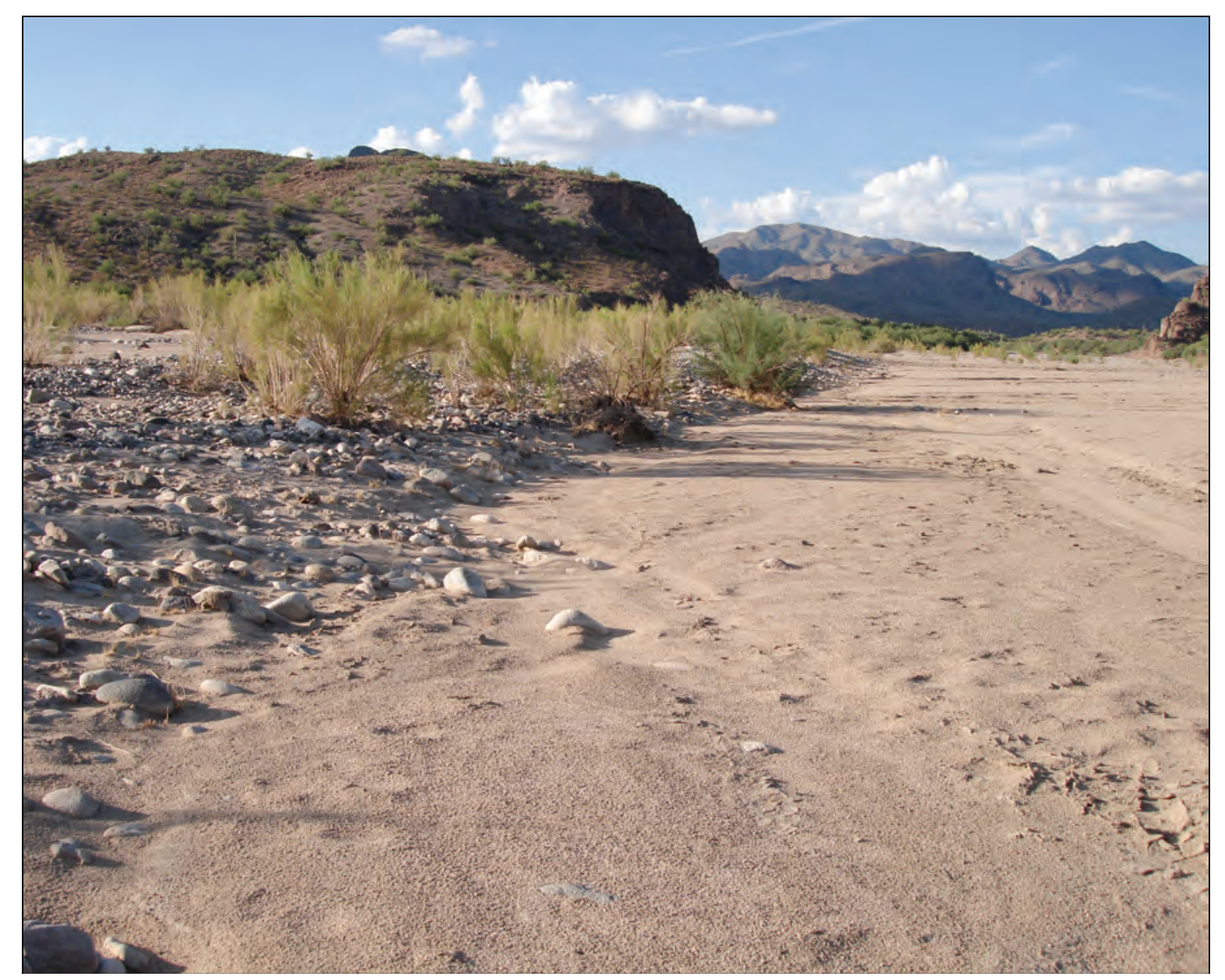




\section{A Field Guide to the Identification of the Ordinary High Water Mark (OHWM) in the Arid West Region of the Western United States}

A Delineation Manual

Robert W. Lichvar and Shawn M. McColley

Cold Regions Research and Engineering Laboratory

U.S. Army Engineer Research and Development Center 72 Lyme Road

Hanover, NH 03755-1290

Approved for public release; distribution is unlimited.

Prepared for U.S. Army Corps of Engineers

Wetland Regulatory Assistance Program 


\begin{abstract}
The Ordinary High Water Mark (OHWM) is an approach for identifying the lateral limits of non-wetland waters. However, determining whether any non-wetland water is a jurisdictional "Water of the United States" (WoUS) involves further assessment in accordance with the regulations, case law, and clarifying guidance. In the Arid West region of the U.S., the most problematic Ordinary High Water (OHW) delineations are associated with the ephemeral/intermittent channel forms that dominate the Arid West landscape. This report presents a method for delineating the lateral extent of the non-wetland waters in the Arid West using stream geomorphology and vegetation response to the dominant stream discharge.
\end{abstract}

DISCLAIMER: The contents of this report are not to be used for advertising, publication, or promotional purposes. Citation of trade names does not constitute an official endorsement or approval of the use of such commercial products. All product names and trademarks cited are the property of their respective owners. The findings of this report are not to be construed as an official Department of the Army position unless so designated by other authorized documents. 


\section{Contents}

Preface vi

1 Introduction .......................................................................................................................

1.1 Ordinary High Water $(\mathrm{OHW})$ in the Arid West Region ...................................................1

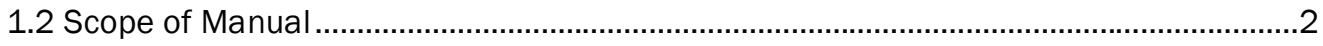

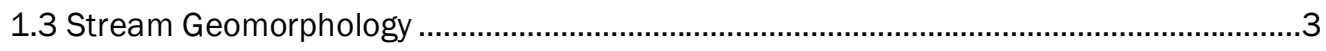

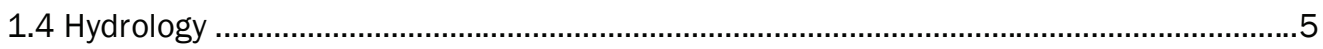

1.5 Arid West Channel Forms of Interest .........................................................................

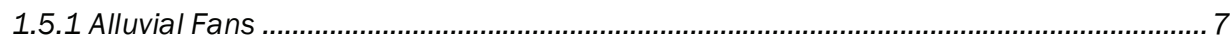

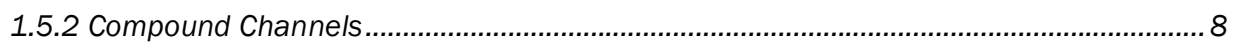

1.5.3 Discontinuous Ephemeral Channels............................................................................. 9

1.5.4 Single-Thread Channels with Adjacent Floodplains......................................................10

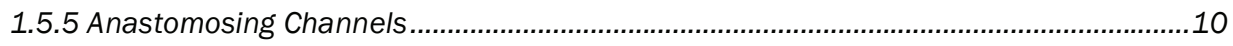

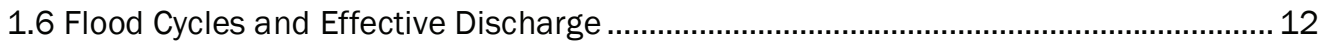

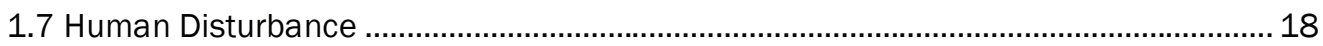

2 OHWM Delineation Background ................................................................................................ 20

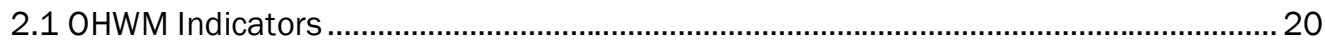

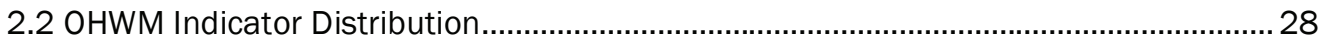

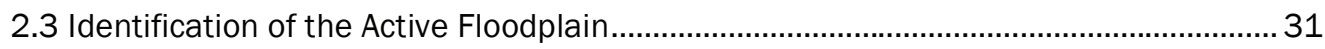

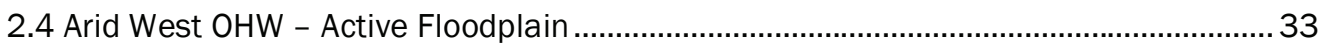

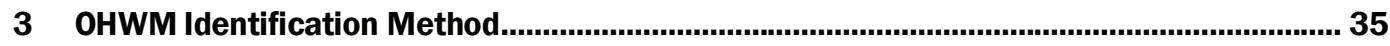

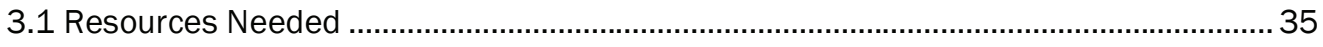

3.1.1 Aerial Photography and Other Imagery .......................................................................35

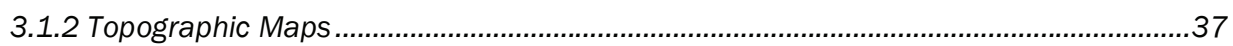

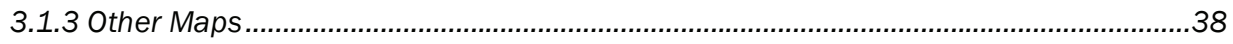

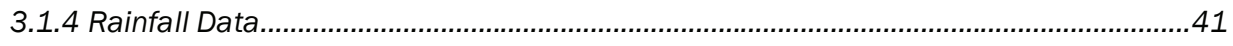

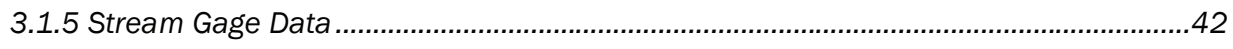

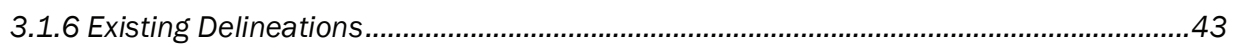

3.2 Preliminary Delineation Procedure ................................................................................. 43

3.3 Field Verification of the Preliminary Delineation ........................................................... 49

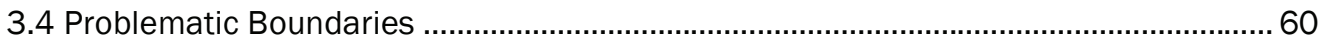

3.5 Examples of Delineations by Channel Form................................................................. 61

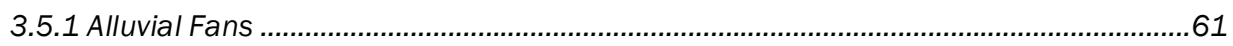

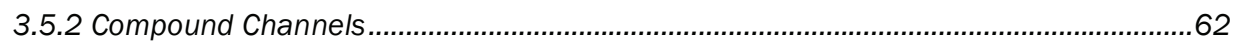

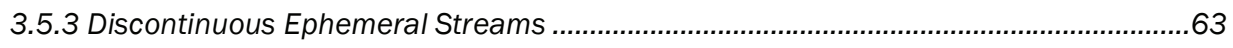

3.5.4 Single-Thread Channels with Adjacent Floodplains....................................................64

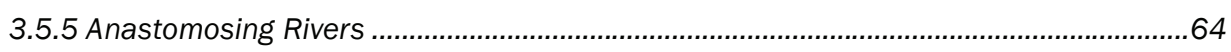

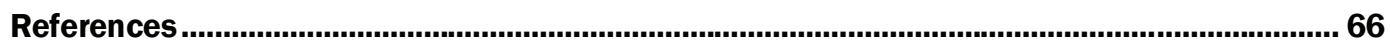

Report Documentation Page ....................................................................................................... 77 


\section{Figures and Tables}

\section{Figures}

Figure 1. Geographic extent of the Arid West region

Figure 2. Representative cross sections depicting hydrogeomorphic floodplain units for perennial channel forms and intermittent/ephemeral channel forms

Figure 3. Shift in the low-flow channel following a 5- to 10-year discharge event at Mission Creek, CA

Figure 4. Alluvial fan with distributary channels at the confluence of the Colorado River and Bright Angel Creek, Grand Canyon, AZ

Figure 5. Compound channel with a low-flow feature in the foreground, Mojave River, CA ................9

Figure 6. Erosional reach (arroyo) along a discontinuous ephemeral channel, Susie Creek, NV ......9

Figure 7. Single-thread channel with adjacent floodplain, Alter Wash, NV ........................................ 10

Figure 8. Anastomosing channels along Cooper Creek, Australia ..................................................... 11

Figure 9. Changes in channel form along an ephemeral stream channel ........................................ 12

Figure 10. Model of changes within the active floodplain and low-flow channel associated with discharge events

Figure 11. Pre-effective discharge and post-effective discharge on the Mojave River at Afton Canyon

Figure 12. Aerial photo time-series acquired over a section of the San Carlos River, AZ, and their corresponding annual peak-flow hydrograph

Figure 13. Lateral and longitudinal variability of geomorphic indicator position along a hypothetical Arid West channel form

Figure 14. Hydrogeomorphic units and OHWM indicator positions within the Mission Creek study reach 29

Figure 15. Mean \pm one standard deviation for each indicator type identified within the Mission Creek study reach 29

Figure 16. Conceptual model showing the locations of OHW indicators 30

Figure 17. Active floodplain/low terrace boundary in an Arid West channel

Figure 18. Vegetative shift at the active floodplain/low terrace boundary in an Arid West channel 32

Figure 19. Examples of changes in vegetative cover and species between the active floodplain and the low terrace 34

Figure 20. Aerial photograph acquired over Chinle Creek, AZ ... 36

Figure 21. Section of a topographic map of the Fried Liver Wash Quadrangle, CA ..........................38

Figure 22. Section of a geologic/topographic map of the Frazier Creek Quadrangle, NV ............... 39

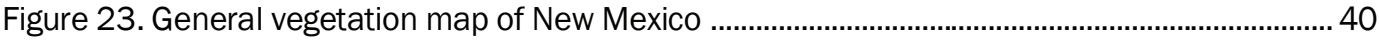

Figure 24. Section of a soils map of the Frasier Flat Quadrangle, NV ................................................ 41

Figure 25. Distribution of precipitation over a portion of northern California .................................... 42 
Figure 26. Flood frequency analysis results produced by HEC-SSP in accordance with Bulletin 17B for the Puerco River, near Chambers, AZ, and for the Mojave River at Afton Canyon, $\mathrm{CA}$

Figure 27. Discharge values associated with 2-, 5-, 10-, and 25-year events for gage 09396100 on the Puerco River near, Chambers, AZ, and for gage 10263000 on the Mojave River at Afton Canyon, CA

Figure 28. Discharge history for the Puerco River near Chambers, AZ, and for the Mojave River at Afton Canyon, CA

Figure 29. Shift-adjusted rating curve for gage 09396100 on the Puerco River, near Chambers, AZ, and for gage 10263000 on the Mojave River at Afton Canyon, CA 48

Figure 30. Step 1 of the field verification procedure 49

Figure 31. Step 2 of the field verification procedure 50

Figure 32. Step 3 of the field verification procedure 51

Figure 33. Step 4 of the field verification procedure 52

Figure 34. Step 5 of the field verification procedure 53

Figure 35. Step 6 of the field verification procedure 54

Figure 36. Step 7 of the field verification procedure ……………………………………………... 55

Figure 37. Step 8 of the field verification procedure …………………………………................... 55

Figure 38. Staff used to determine stage height for Chinle Creek, AZ ………...................................56

Figure 39. Projection onto the landscape of the stage height associated with the most recent effective discharge that exceeded a 5-year event.

Figure 40. Example geomorphic mapping of a compound channel showing a mosaic of terraces within the active floodplain, Caruthers Creek, CA

Figure 41. Example geomorphic mapping of a discontinuous ephemeral stream in an erosional reach (arroyo), Susie Creek, NV

Figure 42. Example geomorphic mapping in a straight reach of a single-thread channel with an adjacent floodplain, Alter Wash, AZ

\section{Tables}

Table 1. Comparison by stream type of flood return interval and features associated with hydrogeomorphic position

Table 2. Primary measurable alluvial fan characteristics .....................................................................

Table 3. Natural controls on fluvial processes ………….................................................................. 15

Table 4. Human controls on fluvial processes .................................................................................. 19

Table 5. Potential geomorphic OHWM indicators categorized by location below, at, and above ordinary high water

Table 6. Potential vegetation OHWM indicators categorized by location below, at, and above ordinary high water

Table 7. Select geomorphic OHWM indicators that may be present below, at, and above the OHW boundary

Table 8. Select vegetative OHWM indicators that may be present below, at, and above the OHW boundary 27

Table 9. Websites with access to digital imagery 


\section{Preface}

This manual was prepared by Robert W. Lichvar and Shawn M. McColley, both of the Remote Sensing/ GIS and Water Resources Branch, Cold Regions Research and Engineering Laboratory (CRREL), U.S. Army Engineer Research and Development Center (ERDC), Hanover, NH.

Support and funding for this manual was provided by the U.S. Army Corps of Engineers (USACE), Headquarters (HQ) through the Wetland Regulatory Assistance Program (WRAP). Their support is acknowledged and appreciated. Dr. Mark Sudol and Katherine Trott (HQ) are acknowledged for their continued interest and support for this Arid West initiative, which addresses questions unique to this region of the country.

Peer reviews, both external and internal, were provided by Dr. Yong Chung, USACE, Los Angeles District; Dr. Steven Daly, CRREL; Dr. J ohn Field, Field Geologic Services; Dr. Richard French, University of Texas at San Antonio, San Antonio, TX; Dr. David Goldman, CRREL; and Dr. Eric Stein, Southern California Coastal Research Project, Westminster, CA.

In addition, technical reviews of various drafts of this manual were provided by Dr. Aaron Allen, USACE, Los Angeles District; Marjorie Blaine, USACE, Los Angeles District; Ann Campbell, U.S. Environmental Protection Agency (EPA); Donna Downing, EPA; Michael Finan, USACE, Sacramento District; Dan Martel, USACE, San Francisco District; J ennifer McCarthy, USACE HQ, Regulatory Community of Practice; Nita TallentHalsell, EPA; Brian Topping, EPA; Michael R Turaski, USACE, Portland District; R. Dan Smith, Environmental Laboratory (EL), ERDC; Dr. J ames Wakeley, EL, ERDC; and James Wood, USACE, Albuquerque District.

Technical support was provided by Michael Ericsson, Dave Finnegan, and Walter Ochs, all of the RS/ GIS and Water Resources Branch, CRREL.

The report was prepared under the general supervision of Timothy Pangburn, Chief, RS/ GIS and Water Resources Branch; Dr. Lance Hansen, Deputy Director; and Dr. Robert E. Davis, Director, CRREL.

The Commander and Executive Director of ERDC is COL Gary E. J ohnston. The Director is Dr. James R. Houston. 


\section{Introduction}

\subsection{Ordinary High Water (OHW) in the Arid West Region}

The Ordinary High Water Mark (OHWM) is a defining element for identifying the lateral limits of non-wetland waters. However, determining whether any non-wetland water is a jurisdictional "Water of the United States" (WoUS) involves further assessment in accordance with the regulations, case law, and clarifying guidance. Federal jurisdiction over a non-wetland WoUS extends to the OHWM, defined in 33 CFR Part 328.3 as the line on the shore established by fluctuations of water and indicated by physical characteristics such as a clear, natural line impressed on the bank, shelving, changes in the character of the soil, destruction of terrestrial vegetation, or the presence of litter and debris. In the Arid West region of the United States (Fig. 1), waters are variable and include ephemeral/intermittent and perennial channel forms. The most problematic ordinary high water (OHW) delineations are associated with the commonly occurring ephemeral/intermittent channel forms that dominate the Arid West landscape. The climate of the region drastically influences the hydrology, channel-forming processes, and distribution of OHWM indicators such that delineations can be inconsistent (over space and time) and problematic. Based on recent research and testing, coupled with years of observations and data gathering, we present here a method for delineating non-wetland waters in the Arid West. This method uses stream geomorphology and vegetation response to the dominant stream discharge and represents the most consistent and repeating pattern associated with "ordinary" events representing OHW.

The geographic extent of this manual is the Arid West region, as defined by Land Resource Regions (LRR) B, C, and D (USDA Natural Resources Conservation Service 2006) (Fig. 1). 


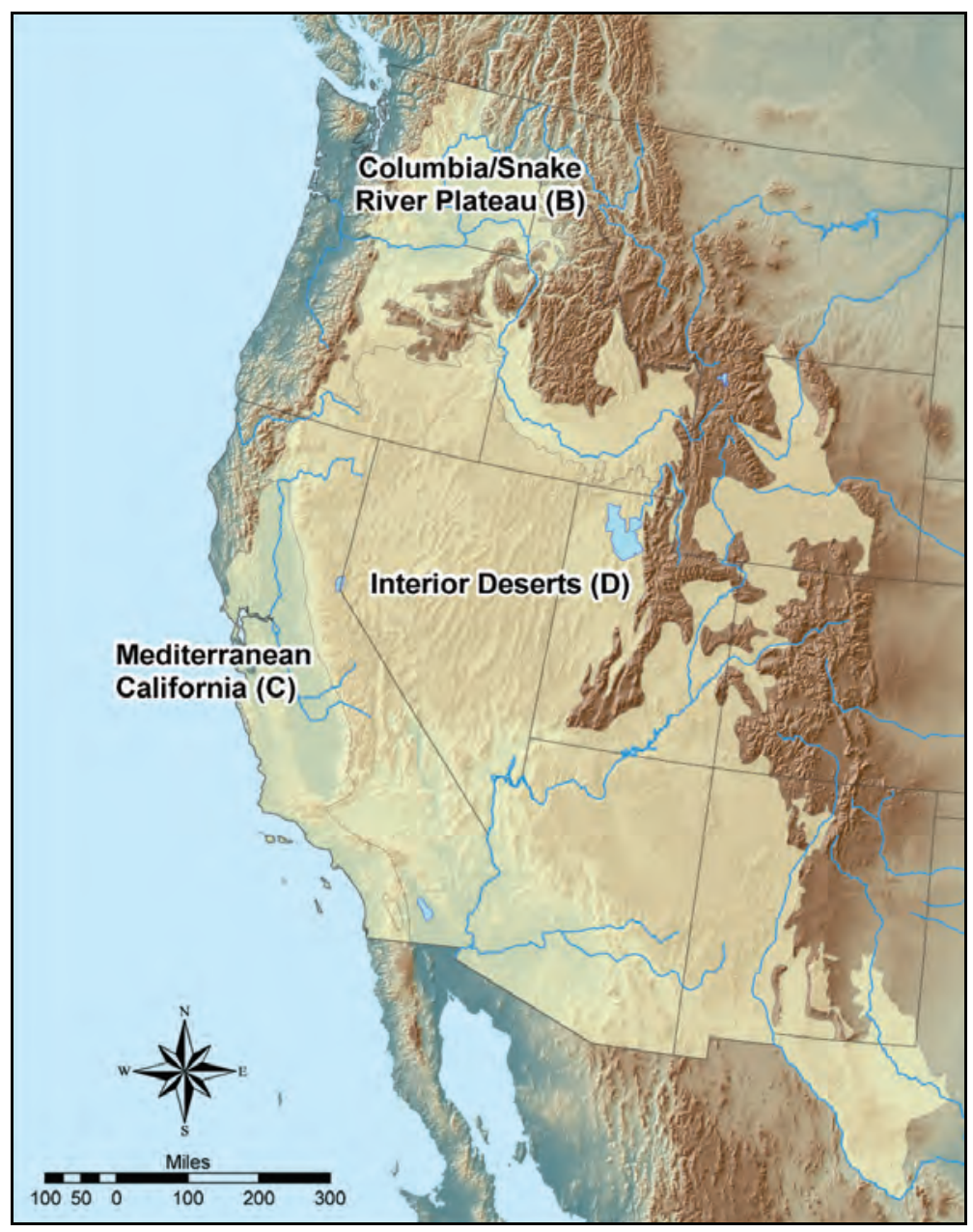

Figure 1. Geographic extent of the Arid West region. (Modified from U.S. Army Corps of Engineers 2006.)

\subsection{Scope of Manual}

The methodology presented in this manual is limited to one element of the delineation procedure for non-wetland waters in the Arid West region. Specifically, this manual addresses the identification of the OHWM in lowgradient, alluvial ephemeral/intermittent channel forms in the Arid West for use in the delineation of non-wetland waters. Although there may be some commonality in OHWM indicators observed in alluvial channel forms and other channel forms (e.g., bedrock) found in arid climates, the procedures presented in this manual are not intended for use in those settings. 


\subsection{Stream Geomorphology}

Watershed characteristics and the local hydrologic regime influence the geometry of the channel and the surrounding floodplain by dictating the amount of sediment deposited and eroded in the channel. Whether in flashy (episodic) arid environments or humid regions with more evenly distributed channel discharges, several common fluvial features are associated with perennial channels. These features, typical of the channel and floodplain, include bankfull, active floodplain, and low terrace zones (Fig. 2). In perennial channels the bankfull zone is where the majority of the impact (via erosion and sedimentation) takes place owing to the presence of the dominant channel-forming discharge. The active floodplain zone receives frequent overbank flood flow. The terrace zone ranges from paleo surfaces that are completely abandoned to modern surfaces that infrequently receive flood waters, typically referred to as the 100-year floodplain.

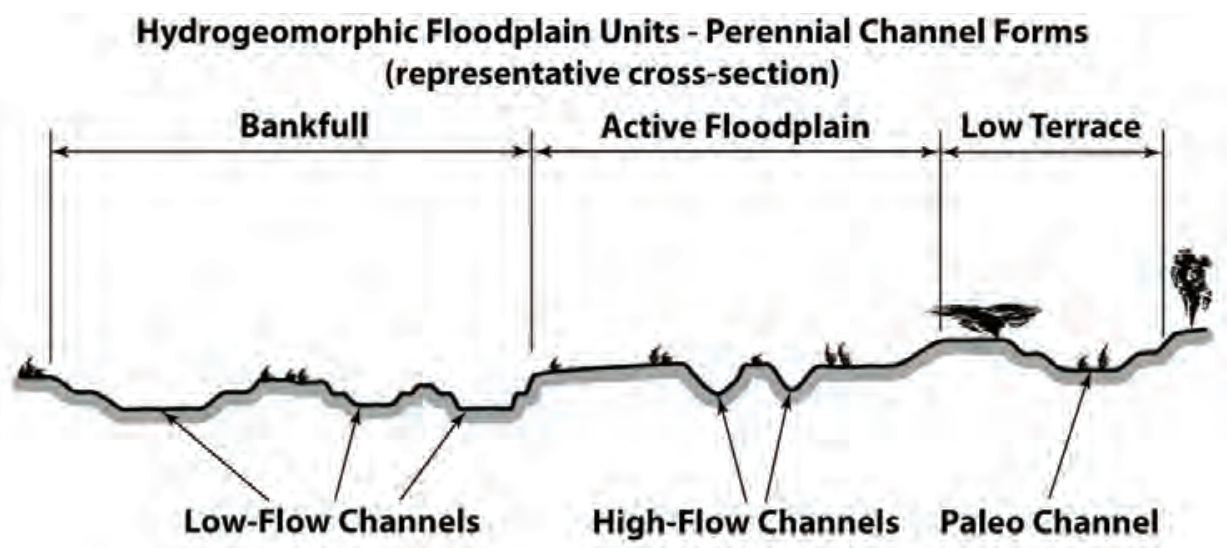

Hydrogeomorphic Floodplain Units - Intermittent and Ephemeral Channel Forms (representative cross-section)

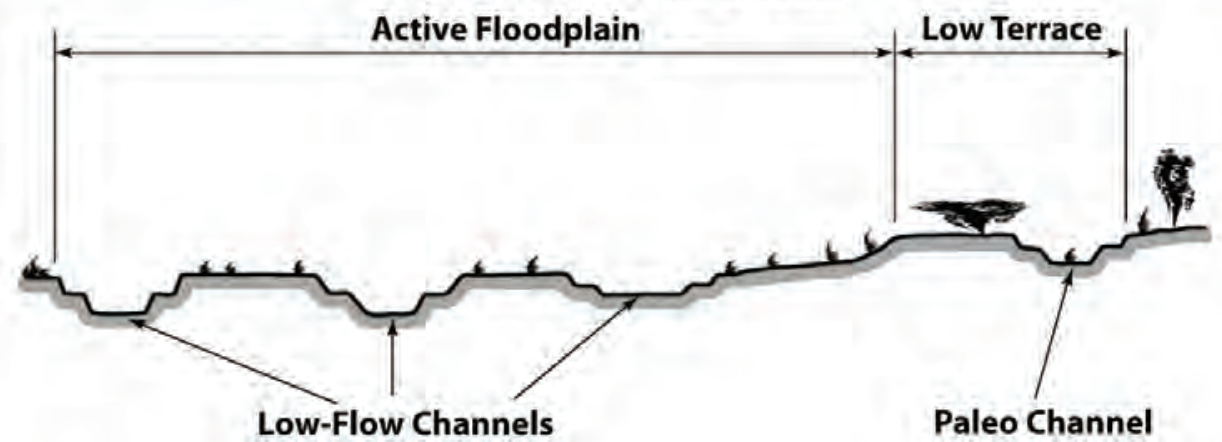

Figure 2. Representative cross sections depicting hydrogeomorphic floodplain units for perennial channel forms (top) and intermittent/ ephemeral channel forms (bottom). 
The geometry of ephemeral/intermittent channels differs from that of perennial channels (Fig. 2). The bankfull zone in a perennial channel is a product of conveying the dominant channel-forming discharge. In ephemeral/intermittent channels, the bankfull zone is potentially a more transient, less discernable feature, and the dominant channel-forming discharge, which is similar in concept to the bankfull event of a perennial channel form, is conveyed by one or more low-flow features in the active floodplain zone. Although there are similarities (Table 1) between the bankfull zone of a perennial channel and the low-flow features of ephemeral/intermittent channels, two critical differences exist: 1) the lowflow features tend to be formed and may be relocated (Fig. 3) during lowto moderate-discharge events (5-10 yr), owing to the immature and poorly formed/consolidated soils typically found in arid systems, and 2) the lowflow features are very dynamic due to a lack of stabilizing vegetation cover and flashy (episodic) discharge patterns.

Table 1. Comparison by stream type of flood return interval and features associated with hydrogeomorphic position.

\begin{tabular}{|c|c|c|}
\hline & Perennial Channel Forms & $\begin{array}{c}\text { Ephemeral/Intermittent } \\
\text { Channel Forms }\end{array}$ \\
\hline \multicolumn{3}{|c|}{ Bankfull/Low flow channel } \\
\hline Return interval & Low (1.4-1.6 yr) (Leopold et al. 1964, Rosgen 1996) & 2 yr (Lichvar et al. 2006) \\
\hline Features & $\begin{array}{l}\text { - Well-defined bed and bank } \\
\text { - Stable over time } \\
\text { - } \underline{\text { Where majority of the impact (erosion/deposition) }} \\
\text { - Decurs } \\
\text { Distinct vegetation }\end{array}$ & $\begin{array}{l}\text { - Unstable over time } \\
\text { - Well-defined to absent bed and } \\
\text { bank } \\
\text { - Shifts during low to moderate } \\
\text { events (Fig. 3) }\end{array}$ \\
\hline \multicolumn{3}{|c|}{ Active floodplain } \\
\hline Return interval & Moderate (2-10 yr) (Riggs 1985) & 5-10 yr (Lichvar et al. 2006) \\
\hline Features & $\begin{array}{l}\text { - Overflow from bankfull channel } \\
\text { - High-flow channels } \\
\text { - Break in slope at margin common } \\
\text { - Distinct vegetation }\end{array}$ & $\begin{array}{l}\text { - Break in slope at margin common } \\
\text { - Stable over time } \\
\text { - Where majority of the impact } \\
\text { - Distinct vegetation }\end{array}$ \\
\hline \multicolumn{3}{|c|}{ Low terrace } \\
\hline Return interval & Infrequent (> 10 yr) & $>10 \mathrm{yr}$ \\
\hline Features & $\begin{array}{l}\text { - Isolated depressions } \\
\text { - Overbank flow during extreme events } \\
\text { - Paleo-channels } \\
\text { - Distinct vegetation }\end{array}$ & $\begin{array}{l}\text { - Isolated depressions } \\
\text { - Overbank flow during extreme } \\
\text { events } \\
\text { - Paleo-channels }\end{array}$ \\
\hline
\end{tabular}




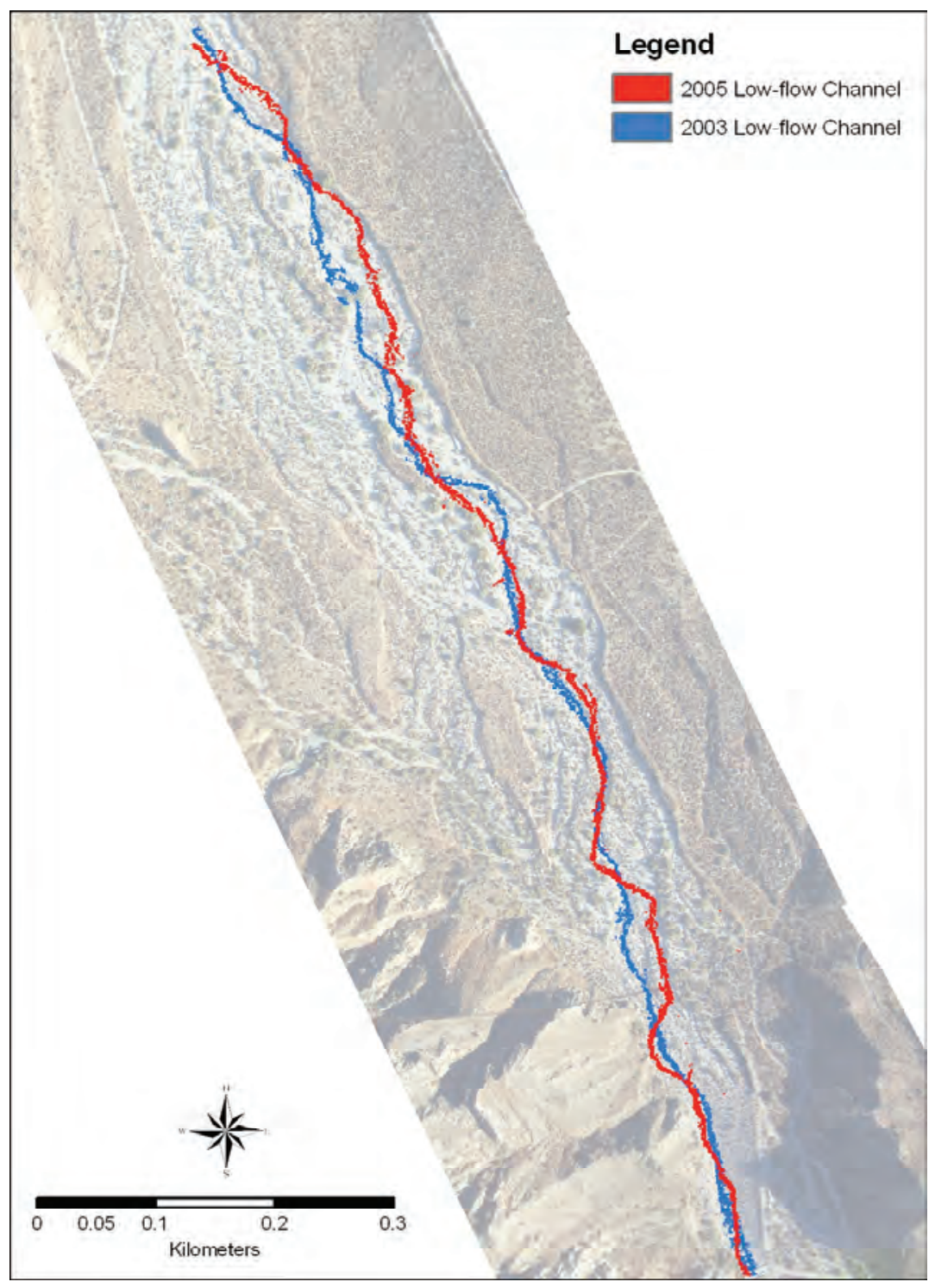

Figure 3. Shift in the low-flow channel following a 5- to 10year discharge event at Mission Creek, CA.

\subsection{Hydrology}

Channel morphology is driven in large part by the discharge patterns associated with the local hydrologic regime. In the Arid West, stream discharges are driven by three large-scale weather patterns (Lichvar and Wakeley 2004): winter North Pacific frontal storms, summer convective thunderstorms, and late-summer eastern North Pacific tropical storms (Ely 1997). These weather patterns produce different types of precipitation events: winter storms are typically of long duration (several days) and low intensity, whereas summer storms are brief but potentially very intense. Precipitation produced by these weather patterns varies greatly on an 
annual and interannual basis for any given locality, but generally, the season of peak precipitation shifts from winter in the north to summer in the south. The variation of precipitation in time, coupled with the orographic effect of highly variable topography across the Arid West, results in spatially variable precipitation patterns (Reid and Frostick 1977, Graf 1988a).

Typically, higher elevations tend to receive greater precipitation than lowlying areas (Lichvar and Wakeley 2004). Snowpack in mountainous regions may act as a buffer for mountain channel forms through moderating the release of runoff supplying more-consistent, lower-energy flow in the spring and early summer months. Alternatively, rainfall on a deep snowpack, which accumulated during a colder period, could result in high-energy flow and flooding of mountain channel forms while adjacent lower elevation channel forms remain dry (Lichvar and Wakeley 2004). Extreme weather events (e.g., summer thunderstorms) may produce locally intense precipitation over an entire watershed or perhaps just a portion of a watershed producing short-duration, potentially high-energy (depending on watershed size, relief, and soil conditions) flow in these areas and a complete lack of flow in others. The spotty, episodic

precipitation patterns often lead to a lack of base flow (unless groundwater influences are present) and, as a result, decreased incision of Arid West channel forms. The lack of consistent flow in conjunction with the immature and poorly formed/ consolidated soils typically found in arid systems make both the channel morphology and the channel position highly variable and generally reduce the growth of channel-armoring vegetation (Reid and Laronne 1995, Millar 2000, Lichvar and Wakeley 2004).

\subsection{Arid West Channel Forms of Interest}

Five major ephemeral/intermittent channel forms occur within the Arid West: (1) alluvial fans, (2) compound channels, (3) discontinuous ephemeral channels, (4) single-thread channels with associated floodplains, and (5) anastomosing channels. Each channel form may transition from one to another through space and time. At a delineation site, the current channel type can be determined through the use of a formal channel classification scheme (e.g., Rosgen 1996); however, classification is not required to perform delineations because all five channel forms are delineated in the same manner. Thus, a brief, 
descriptive overview of each channel form is provided below for background purposes only.

\subsubsection{Alluvial Fans}

Alluvial fans are widespread in the southwestern United States, where it has been estimated that approximately $31 \%$ of the land surface is covered by alluvial fan deposits (Antsey 1965). Alluvial fans have a general geomorphic form that is cone- or fan-shaped (Fig. 4) and are typically composed of boulders, gravel, sand, and finer sediment. Definitions for these features range from geological, which describe shape and location and include a qualitative treatment of hydraulic processes that result in flood hazard, to the regulatory FEMA definition, which delineates the type of alluvial fan that is most hazardous to public health and safety by itemizing the hydraulic processes expected to occur on a generic alluvial fan (French et al. 1993).

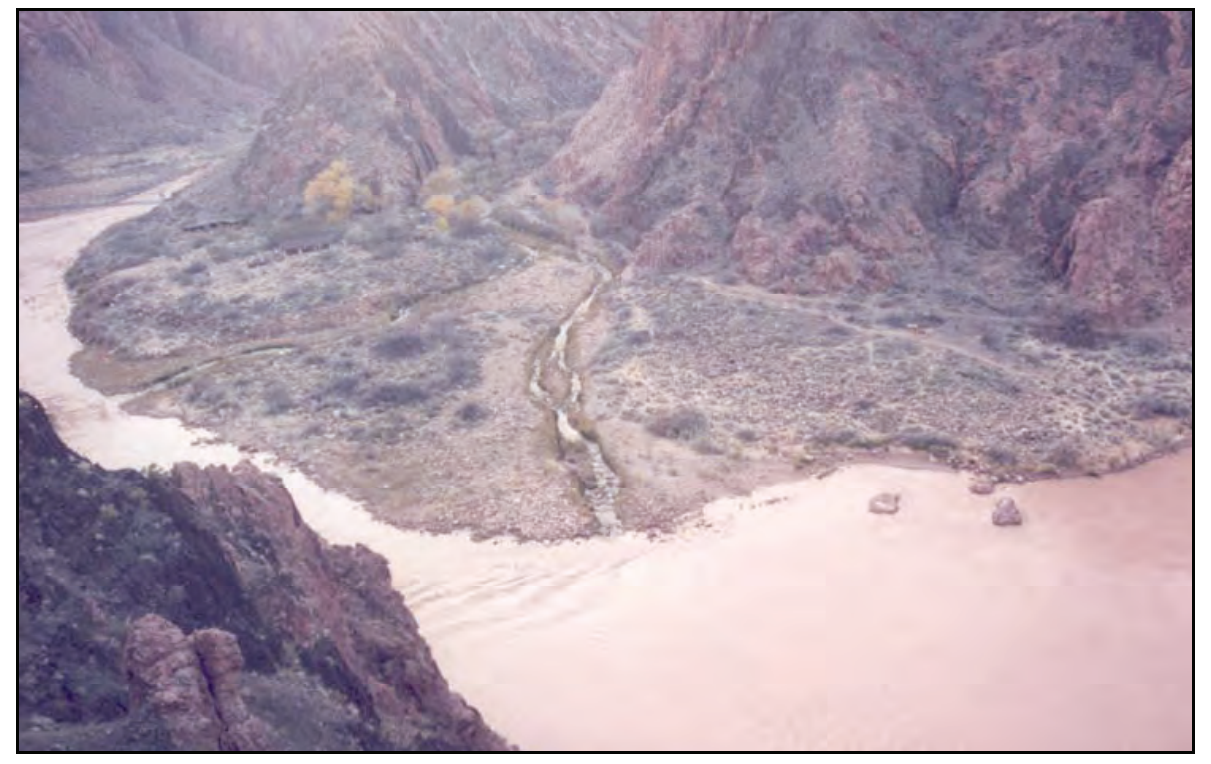

Figure 4. Alluvial fan with distributary channels at the confluence of the Colorado River and Bright Angel Creek, Grand Canyon, AZ (Lichvar and Wakeley 2004).

Measurable characteristics (Table 2) can be used to differentiate between three types of alluvial fans: (1) active alluvial fans, (2) distributary flow systems, and (3) inactive alluvial fans (French et al. 1993). Several processes may be observed on an active alluvial fan, including channel migration, debris flow, hyperconcentrated sediment transport, channel bank erosion, local bed scour, and flash flooding (French et al. 1993). Processes that occur in distributary flow areas include local scour and fill, 
divergent flow, stream capture, flash flooding, hyperconcentrated sediment transport, and shifting of runoff among existing channels due to vegetative and/ or sediment debris dams (French et al. 1993). Inactive alluvial fans experience sheetflow, channel bank erosion, local deposition or scour, flash flooding, and hyperconcentrated sediment transport (French et al. 1993).

Table 2. Primary measurable alluvial fan characteristics. (Modified from the $\mathrm{CH} 2 \mathrm{M}$ Hill and French 1992.)

\begin{tabular}{|l|l|l|}
\hline \multicolumn{1}{|c|}{ Active Alluvial Fan (1) } & Distributary Flow System (2) & \multicolumn{1}{|c|}{ Inactive Alluvial Fan (3) } \\
\hline $\begin{array}{l}\text { Abandoned/discontinuous } \\
\text { channels }\end{array}$ & Discontinuous channels & Continuous channels \\
\hline $\begin{array}{l}\text { Channel capacity decreases } \\
\text { downstream }\end{array}$ & $\begin{array}{l}\text { No definite trend in channel } \\
\text { capacity }\end{array}$ & $\begin{array}{l}\text { Channel capacity increases } \\
\text { downstream }\end{array}$ \\
\hline Channel flow changes to sheetflow & Channel and sheetflow & $\begin{array}{l}\text { Channelized flow (overbank flow } \\
\text { possible) }\end{array}$ \\
\hline Debris flow possible & Minor (or no) debris flow & No debris flow \\
\hline Frequent channel movement & Rare channel movement & Stable channels \\
\hline Low channel capacity & Variable channel capacity & High channel capacity \\
\hline No calcrete & Calcrete horizons possible & Calcrete horizons \\
\hline No (or buried) desert varnish & Varnished surfaces possible & Varnished surfaces possible \\
\hline No surface reddening of soils & Minor reddening of soils & Surface reddening of soils \\
\hline Overall deposition & Local erosion and deposition & Overall erosion \\
\hline $\begin{array}{l}\text { Radiating channel pattern changes } \\
\text { to sheetflow area }\end{array}$ & Radiating changes to tributary & Tributary drainage pattern \\
\hline Slope decrease downstream & Slope increase at apex & Slope variable \\
\hline Stream capture or avulsions? & $\begin{array}{l}\text { Channel movement by stream } \\
\text { capture }\end{array}$ & No channel movement \\
\hline $\begin{array}{l}\text { Uniform topography (low } \\
\text { crenulation index) }\end{array}$ & $\begin{array}{l}\text { Medium to low topographic relief } \\
\text { (medium to low crenulation index) }\end{array}$ & $\begin{array}{l}\text { Topographic relief (high } \\
\text { crenulation index) }\end{array}$ \\
\hline Uniform vegetation in floodplain & Diverse vegetative community & Diverse vegetative community \\
\hline Variable channel geometry & Variable channel geometry & Regular channel geometry \\
\hline Weak soil development & Variable soil development & Strong soil development \\
\hline
\end{tabular}

\subsubsection{Compound Channels}

Often considered the most common channel type in dry regions (Tooth 2000), compound channels are characterized by a single, low-flow meandering channel inset into a wider braided channel network (Fig. 5) (Graf 1988a). These channels are highly susceptible to widening and avulsions (channel relocation) during moderate to high discharges, reestablishing a low-flow channel during subsequent low flows. 


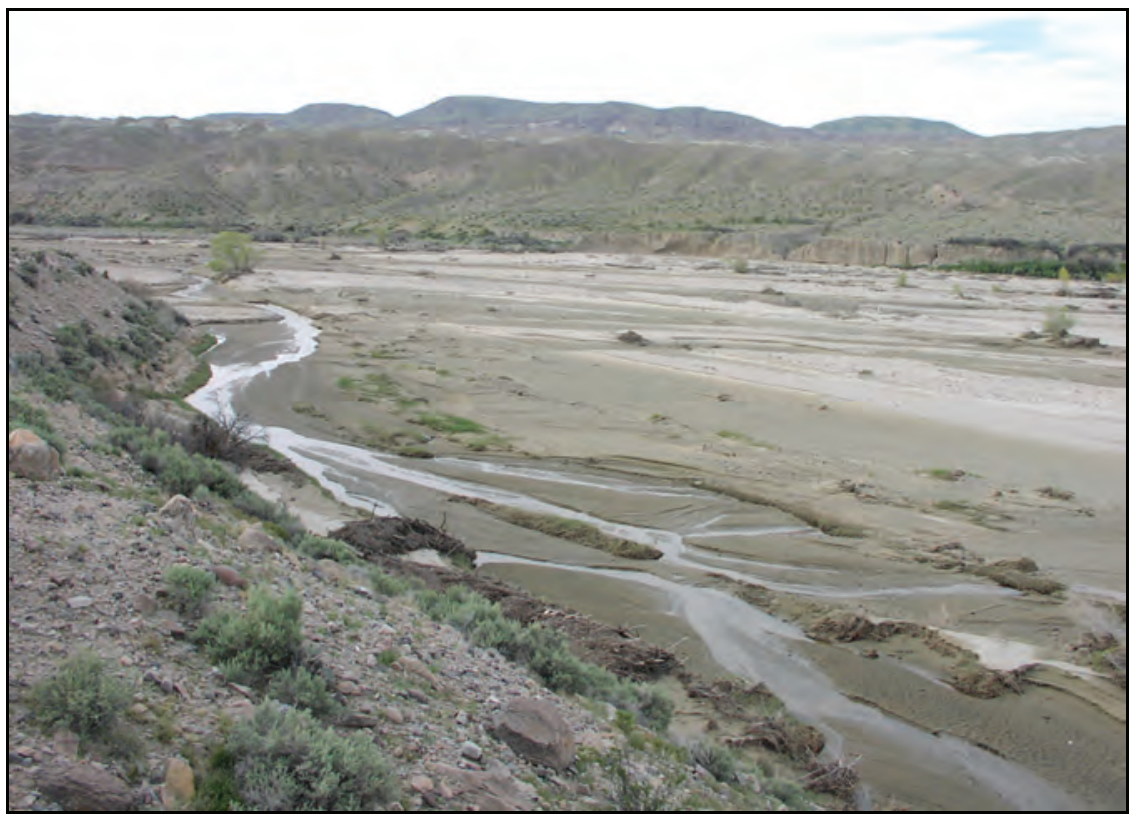

Figure 5. Compound channel with a low-flow feature in the foreground, Mojave River, CA.

\subsubsection{Discontinuous Ephemeral Channels}

These channel forms are characterized by alternating erosional (Fig. 6) and depositional reaches, both of which may vary in length from $15 \mathrm{~m}$ to over $10 \mathrm{~km}$ (Bull 1997). They are constantly in flux, as headcuts (knick

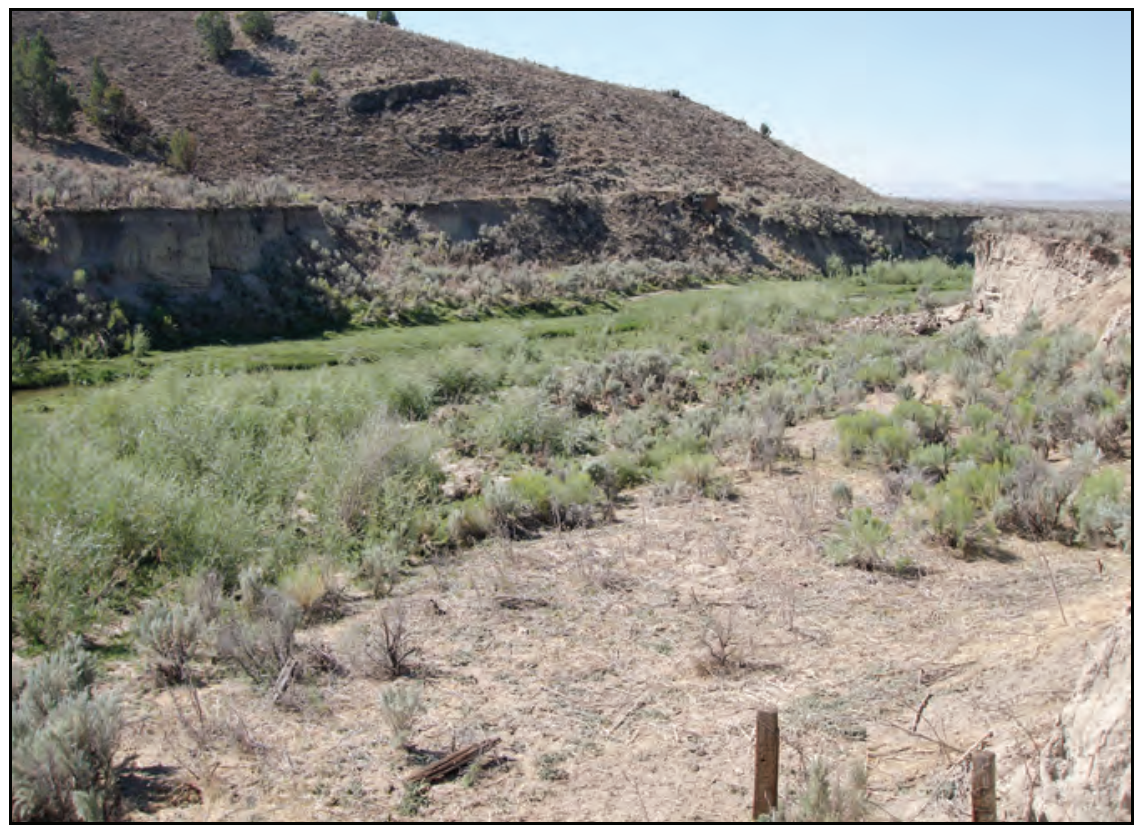

Figure 6. Erosional reach (arroyo) along a discontinuous ephemeral channel, Susie Creek, NV. 
points) originating at the downstream end of the sheetflood zone migrate upstream, causing dramatic temporal and spatial changes in channel morphology for any given location.

\subsubsection{Single-Thread Channels with Adjacent Floodplains}

In the Arid West, occurrences of single-thread channels are often limited to perennial streams and rivers with origins extending into more humid regions, or small streams sourced by local springs. In either case, a more continuous supply of water is present. These streams and rivers consist of a single-thread channel with lateral adjacent floodplains that are either continuous or intermittent along the course of the channel (Fig. 7). In general, the morphologies of arid- and humid-region single-thread channels with adjacent floodplains are similar; however, transmission losses (Reid and Frostick 1997) and debris inputs from tributaries (Graf 1979, Webb et al. 1988), which may alter the form of the channel, are limited to arid-region examples.

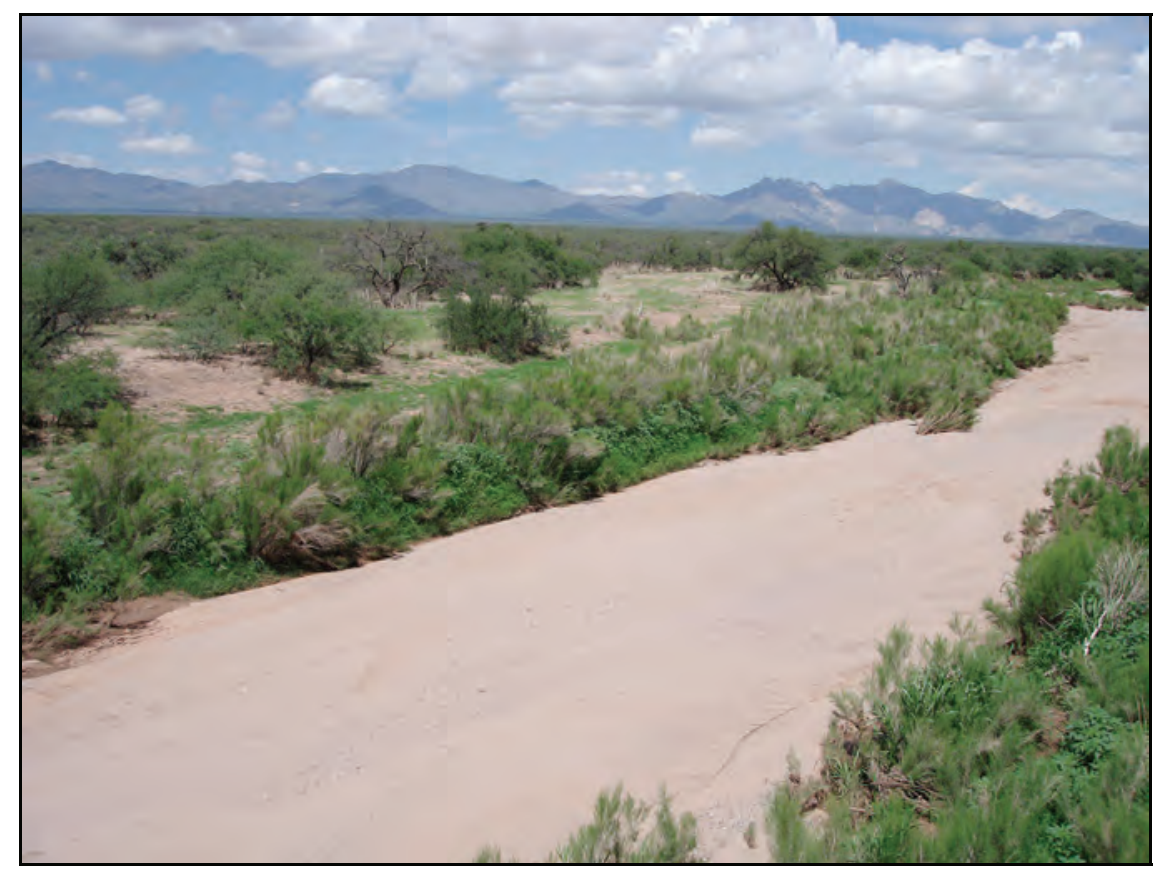

Figure 7. Single-thread channel with adjacent floodplain, Alter Wash, NV.

\subsubsection{Anastomosing Channels}

Anastomosing channel forms (Fig. 8) are multi-thread channels with stable, fine-grained banks, transporting a suspended or mixed load (Schumann 1989). The characteristics necessary for the development of 
anastomosing channels are not widespread in the Arid West, making them uncommon in this region.

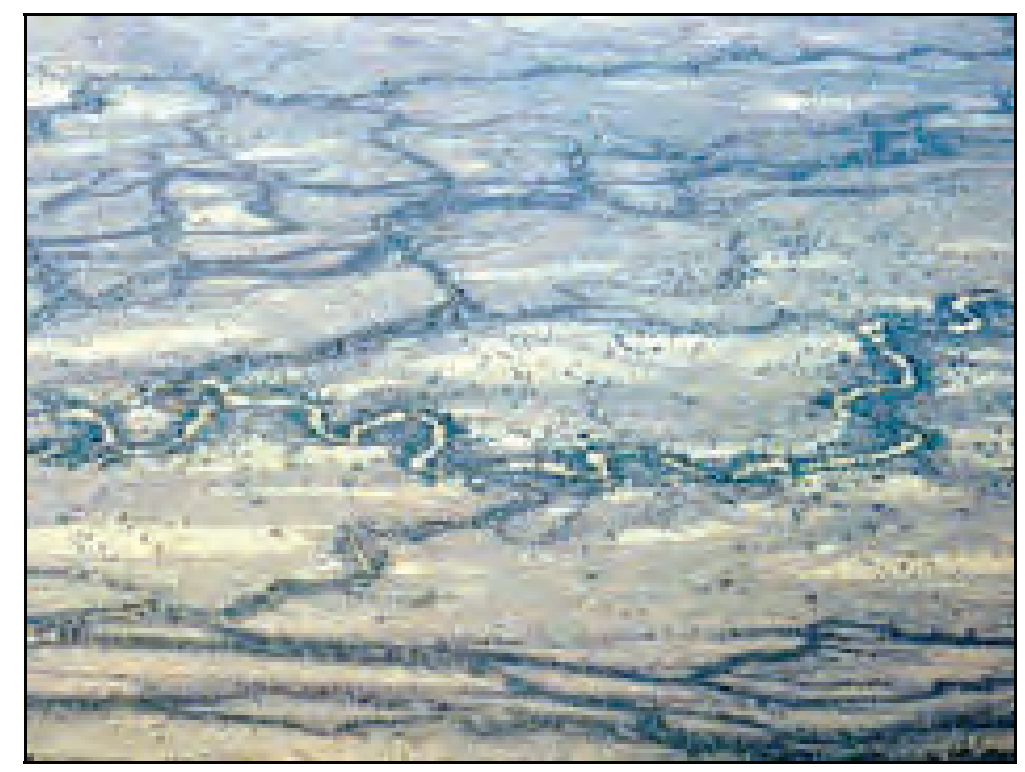

Figure 8. Anastomosing channels along Cooper Creek, Australia. Copyright, Colin P. North, University of Aberdeen, Scotland; used by permission (Lichvar and Wakeley 2004).

Within the channel types discussed, local geology and vegetation often contribute to channel geometry. Local geology plays an important role in (1) the amount, size, and mineralogy of sediment found within the channel system, (2) the channel gradient, and (3) the incision rate. Vegetation can dictate the amount of sediment retained in storage throughout the channel system, and it can increase bank stability.

The channel's position in a watershed places limiting dimensions on the channel geometry because of the size of the contributing drainage area. As distance increases from the headwaters of a watershed, waterways typically transition from bedrock to alluvial channels. The change in substrate to alluvium creates dynamic channel geometries because the bed and banks erode more easily. Figure 9 shows an example of the transition from bedrock (A) to an alluvial (B and C) substrate and the associated change in channel geometry for Caruthers Creek, Mojave Desert, CA. 


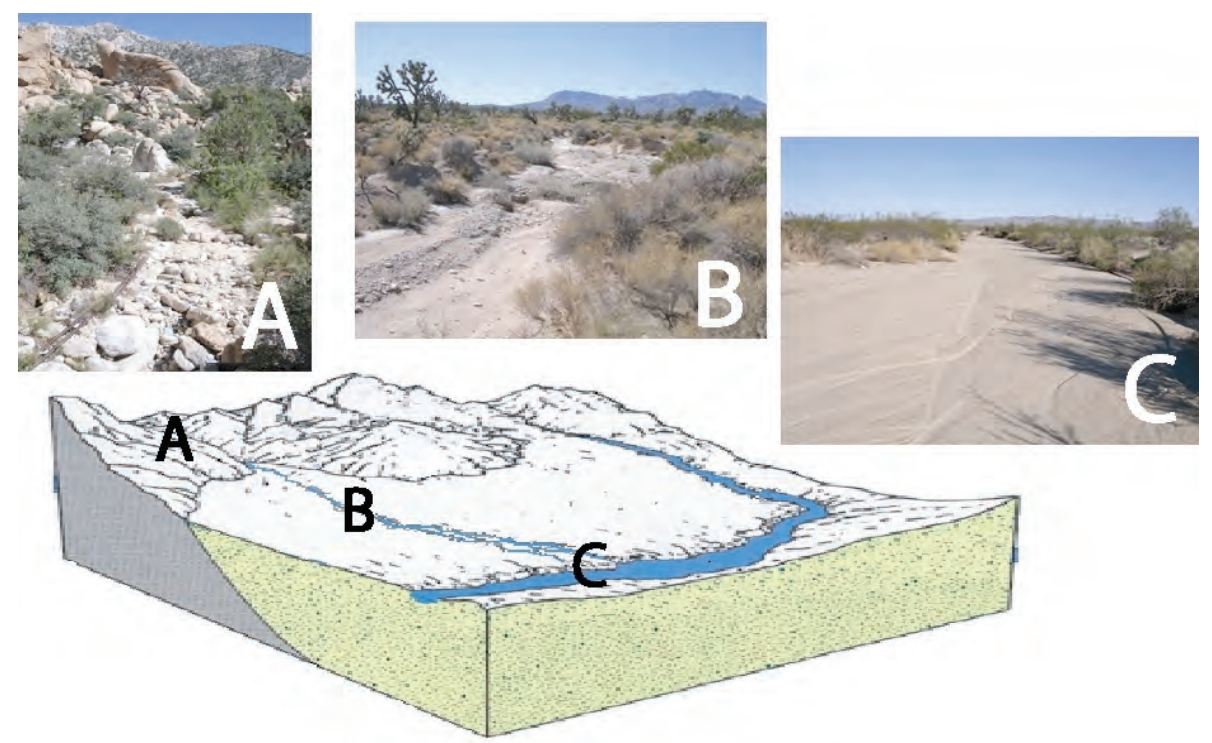

Figure 9. Changes in channel form along an ephemeral stream channel (Caruthers Creek, CA).

\subsection{Flood Cycles and Effective Discharge}

Several weather phenomena contribute to discharge events in channel forms throughout the Arid West region. During the winter months, large regional Pacific storms bring widespread rains to the region, and the El Niño Southern Oscillation (ENSO) has been correlated to increased flood magnitude in southern California (Andrews at al. 2004). In late spring and continuing into September, the North American Monsoon typically delivers moisture to the Interior Desert region of the Arid West, primarily Arizona and New Mexico. In the northern portion of the Arid West region, winter precipitation is dominant, whereas in the southern portion, the majority of the annual precipitation falls in the summer.

The dominant precipitation phenomenon for a given location tends to drive the timing of low to moderate (5- 10 year) discharge events in the Arid West. Low to moderate events are capable of carrying the largest proportion of sediment over time in arid channels, making them the dominant or effective discharges in the region (Wolman and Miller 1960). Such flows scour vegetation from within the channel and change channel geometry by mobilizing significant sediment both in the channel and on the surrounding floodplain. Shifts in vegetative and textural signatures, brought on by the competence or ability of a discharge to rework bed materials (Fig. 10) and detected either on the ground or in aerial photographs, are used to identify the limits of OHW. Cross-section 1 in Figure 10 depicts a condition without an effective discharge for some 
period of time. The low-flow channel is incised into the active floodplain, where abundant vegetation growth is present. Cross-section 2 depicts potential changes resulting from an effective discharge, with removal of vegetation within the active floodplain and in-filling of the low-flow channel. Cross-section 3 shows a potential intermediate condition following the effective discharge and after a number of low-flow events have occurred, resulting in the formation of a low-flow channel and revegetation of the active floodplain. However, another effective discharge could reset the channel back to conditions depicted in Cross-section 2. Knowing the timing of recent effective discharges helps in interpreting channel conditions. The physical characteristics of vegetation maturity, cover, and species; sediment texture; and potential presence of a bank at the active floodplain/ low terrace boundary remain throughout the cycle.

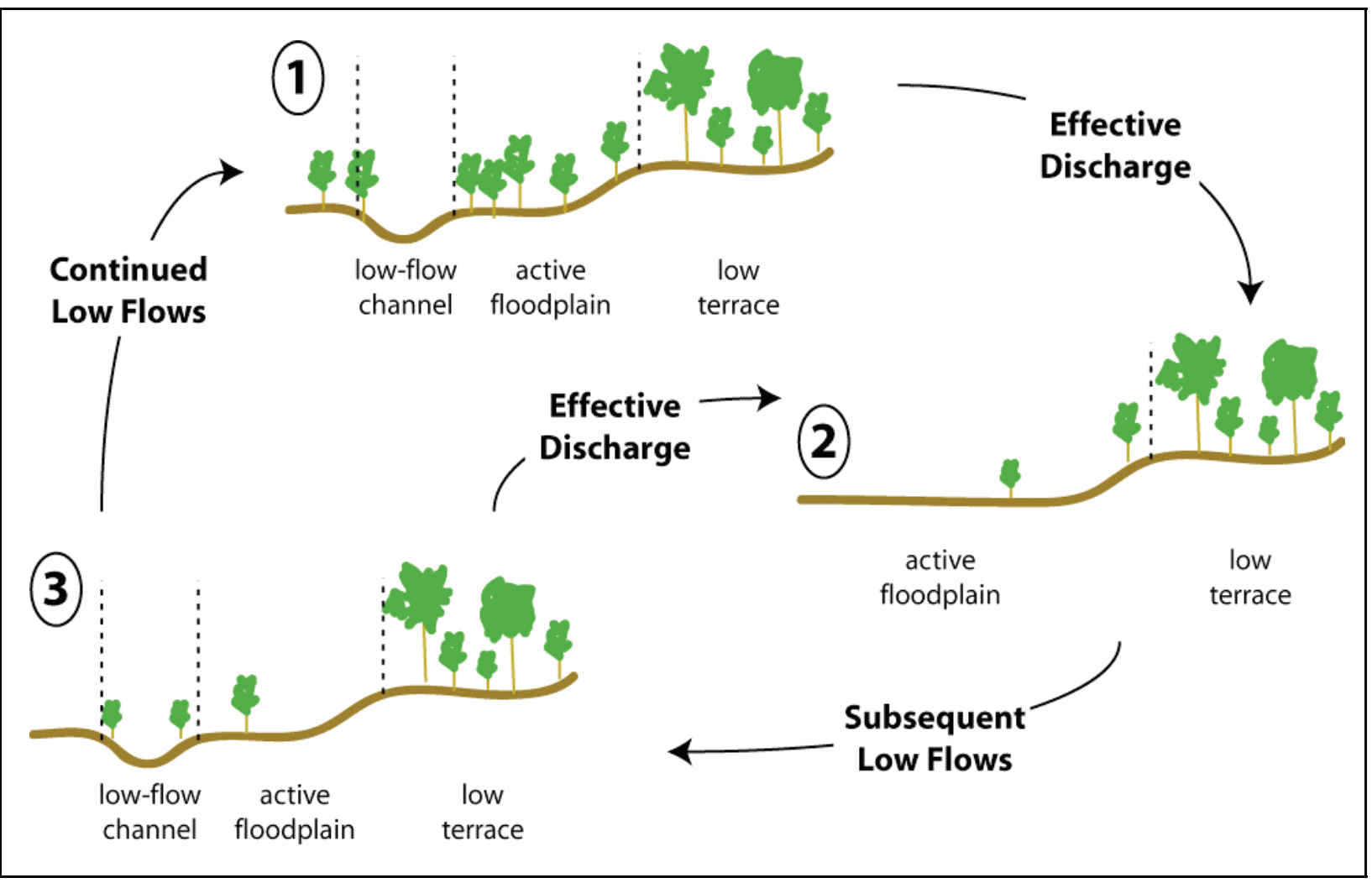

Figure 10. Model of changes within the active floodplain and low-flow channel associated with discharge events. (Note: There may be aggradation or degradation after step 2.) 

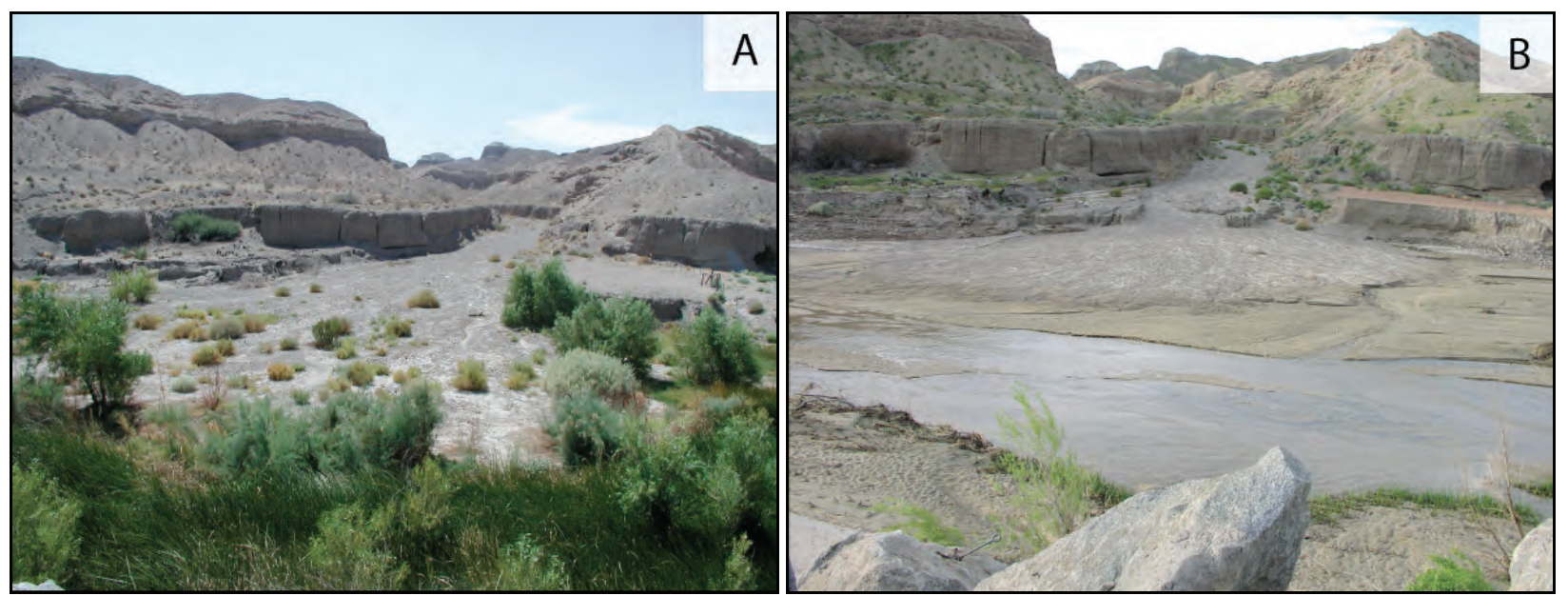

Figure 11. Pre-effective discharge (A) and post-effective discharge (B) on the Mojave River at Afton Canyon. The effective discharge reworked sediment and removed vegetation.

An example of the impact produced by a recent effective discharge for the Mojave River at Afton Canyon in J anuary 2005 is shown in Figure 11. Hydrologic modeling describes these low to moderate effective discharges as occurring roughly every 5- 10 years to an inundation extent that correlates with the limit of the active floodplain (Lichvar et al. 2006). These low to moderate events, which are responsible for the majority of the impact, are similar in concept to the every-other-year frequency of the bankfull discharge (Dunne and Leopold 1978, Rosgen 1996) in more humid regions. However, the low-flow features in Arid West ephemeral/ intermittent channels develop as a result of channel changes occurring during less frequent events. In perennial channel forms, they are the result of the impact produced by more frequent discharges. The physical expression of the impact in ephemeral/intermittent channel forms is variable and is largely driven by the recent flood history, location within the watershed, watershed shape, local geology, and precipitation regime. Table 3 summarizes the conditions under which each channel form develops. 
Table 3. Natural controls on fluvial processes.

\begin{tabular}{|c|c|c|}
\hline Stream Type & Photograph & Natural Processes \\
\hline $\begin{array}{l}\text { Discontinuous } \\
\text { ephemeral } \\
\text { streams }\end{array}$ & 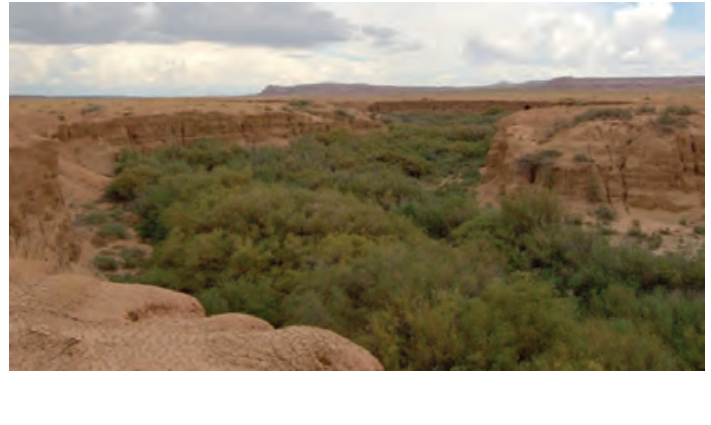 & $\begin{array}{l}\text { - Alternating erosional and depositional } \\
\text { reaches } \\
\text { - Headcuts that form at downstream } \\
\text { end of sheet flood zones and migrate } \\
\text { upstream } \\
\text { - Cycle of arroyo formation, widening, } \\
\text { and backfilling into the valley floors } \\
\text { - System in equilibrium as long as } \\
\text { length of channelized areas relative to } \\
\text { sheet flood zones remains constant }\end{array}$ \\
\hline $\begin{array}{l}\text { Compound } \\
\text { channels }\end{array}$ & 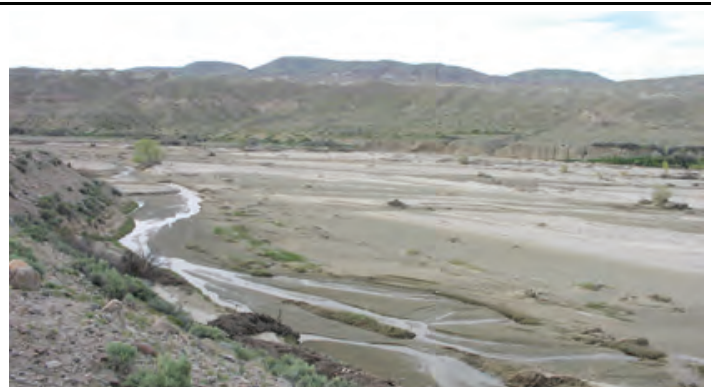 & $\begin{array}{l}\text { - Rapid widening in response to } \\
\text { increase in sediment transport } \\
\text { capacity during extreme, brief, } \\
\text { discharge } \\
\text { - Activation of braided channels after } \\
\text { extreme flow events } \\
\text { - Meandering form that develops after } \\
\text { long sequence of low to moderate } \\
\text { discharges }\end{array}$ \\
\hline $\begin{array}{l}\text { Alluvial } \\
\text { fans }\end{array}$ & & $\begin{array}{l}\text { - Fans that emerge from upland areas } \\
\text { into zones of reduced stream power } \\
\text { and are maintained by distributary } \\
\text { flow } \\
\text { - Enhanced deposition because of } \\
\text { decreased stream power from } \\
\text { headwaters to valley bottom, loss in } \\
\text { flow confinement, and loss of } \\
\text { discharge } \\
\text { - Channel avulsions resulting from } \\
\text { overbank flows emanating from } \\
\text { channels on fan surface }\end{array}$ \\
\hline $\begin{array}{l}\text { Anastamosing } \\
\text { rivers }\end{array}$ & $\begin{array}{l}\text { (Copyright, Colin P. North, University of Aberdeen, Scotland; } \\
\text { used by permission) }\end{array}$ & $\begin{array}{l}\text { - Frequent channel avulsions } \\
\text { - Smaller anabranch channels that } \\
\text { grow headward towards the main } \\
\text { channel in response to overbank } \\
\text { flows emanating from aggrading main } \\
\text { channel }\end{array}$ \\
\hline
\end{tabular}



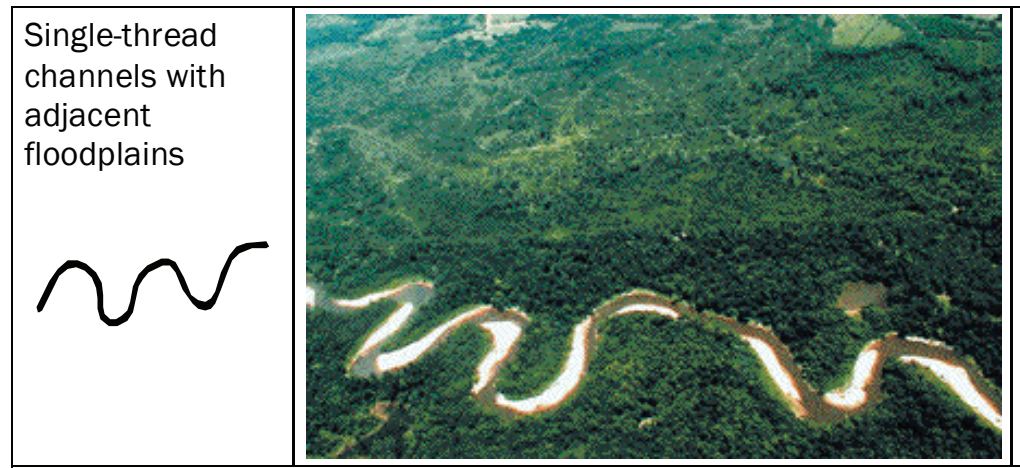

- Meandering that develops to minimize amount of change at any point along river

- Channel incision when sediment transport capacity of reach is elevated relative to sediment supplied to reach

- Channel widening with bank destabilization

- Aggradation due to decrease in capacity to transport sediment

Channel forms may also change in response to a series of effective discharges as depicted in Figure 10. In-filling or migration of the low-flow channel is common as effective discharges recede and is often evident in a time-series of aerial photographs (Fig. 12). The scene in Figure 12 shows the migration/ evolution of numerous low-flow features on a section of the San Carlos River in Arizona. The impact produced by multiple effective events that preceded the acquisition of image $\mathrm{A}$ is distinct and includes the removal of vegetation and the emplacement of a single, predominant lowflow feature within the active floodplain (indicated by the gray area in E). Over the period spanned by images B and C, peak flows were not capable of net sediment transport, resulting in aggradation and channel avulsions that caused the low-flow feature in A to develop into the multiple, discontinuous low-flow features observed in B and C. Also apparent from $\mathrm{B}$ to $\mathrm{C}$ is the increase in channel stability due to vegetation growth and a lack of scour. Image D illustrates the impact within the channel following an effective discharge. Notably, evidence of many of the low-flow features that developed in $\mathrm{B}$ and $\mathrm{C}$ has been removed, vegetation cover has been reduced within the active floodplain (the gray area in $\mathrm{H}$ ), and a single, predominant low-flow feature has been established. Understanding how channels respond to natural disturbances may also prove useful in understanding how the type and position of OHWM features might vary over time at a given location (Field and Lichvar 2007). 

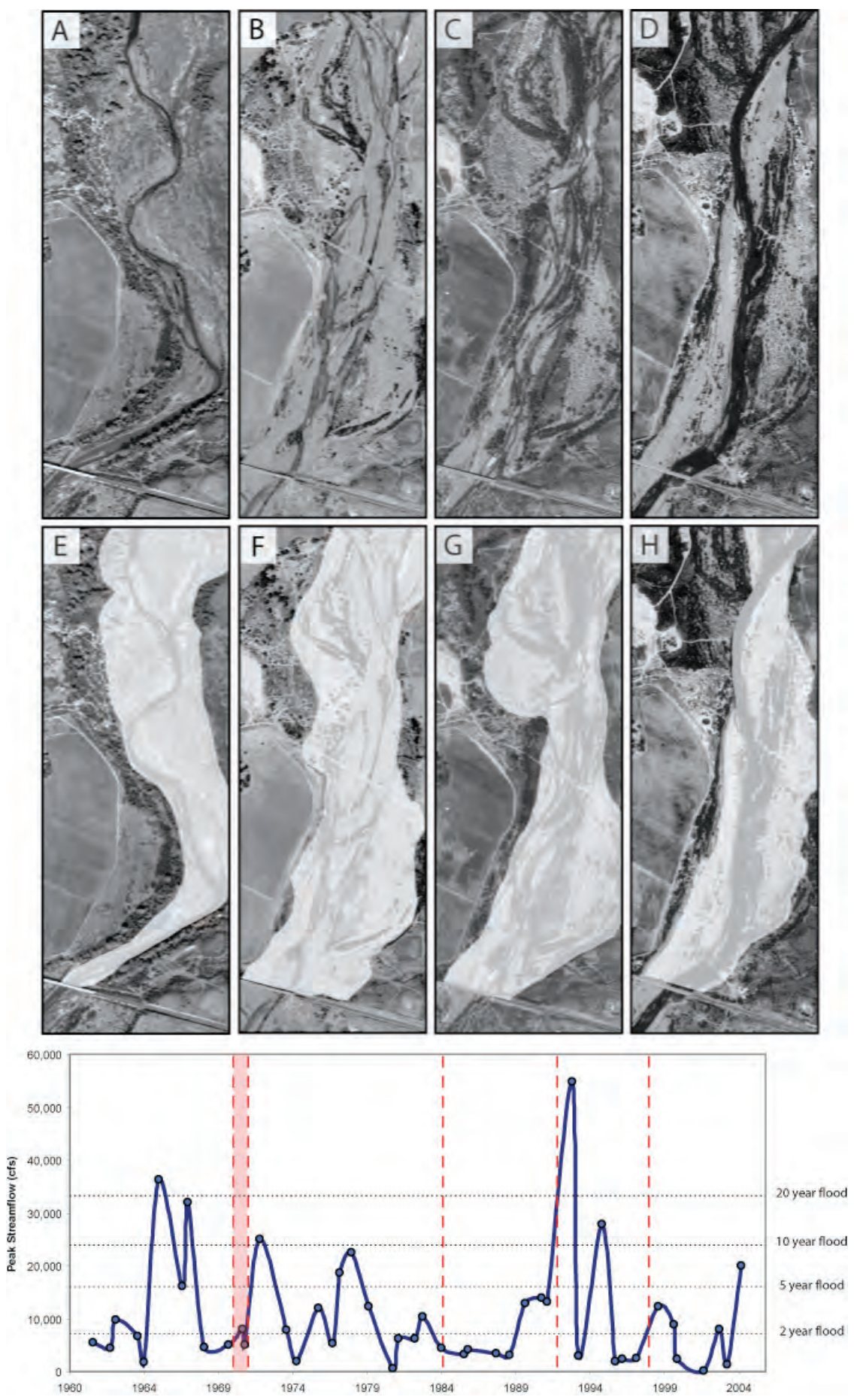

Figure 12. Aerial photo time-series acquired over a section of the San Carlos River, AZ, and their corresponding annual peak-flow hydrograph. The red dashed lines on the hydrograph indicate the time of acquisition for each photo: (A) 1971, (B) 06/08/1984, (C) $10 / 11 / 1992$, and (D) 05/15/1998. The second set of images $(\mathrm{E}, \mathrm{F}, \mathrm{G}$, and $\mathrm{H}$ ) is a duplicate of the top set except that the active floodplain zone is designated by light gray. The active floodplain zone is only indicated for the area to the north of the bridge running diagonally across the bottom of each image. 


\subsection{Human Disturbance}

Human impact can alter the type, distribution, and distinctiveness of the physical features developed at a particular location and therefore affects the OHWM determination. Although an almost limitless number of combinations of human land uses can precipitate a channel response, six human activities have generally been responsible for significant channel adjustments in the Arid West, in terms of both magnitude of change on a particular stream and their widespread occurrence throughout the region: 1) land clearing for agriculture or grazing; 2) urbanization; 3) gravel mining; 4) channelization; 5) dam construction; and 6) flow modification. Common channel responses to each of these activities, at least when occurring in isolation, are fairly well understood and are summarized in Table 4 (Field and Lichvar 2007). The responses may or may not occur together, and their magnitudes may vary greatly. Ultimately, the magnitude of a stream's response to anthropogenic alteration is largely controlled by the complex combination of disturbance intensity, proximity to the stream, and soil and vegetation cover. 
Table 4. Human controls on fluvial processes.

\begin{tabular}{|c|c|}
\hline Human Processes & Common Responses \\
\hline $\begin{array}{l}\text { Land clearing for } \\
\text { agriculture or grazing }\end{array}$ & $\begin{array}{l}\text { - Overgrazing, resulting in exposed soils that are less resistant to } \\
\text { the erosive forces of floods ultimately leading to channel incision } \\
\text { - Increased stream power } \\
\text { - Arroyo cutting on valley-bottom floors into confined steep-walled } \\
\text { arroyos } \\
\text { - Lower water table from groundwater pumping } \\
\text { - Increased streamflow from irrigation runoff } \\
\text { - Slope reduction due to incision and stream power lost from } \\
\text { widening } \\
\text { - Increased sediment-to-water ratio of the flow and beginning of } \\
\text { aggradation }\end{array}$ \\
\hline Urbanization & $\begin{array}{l}\text { - Channel incision and enlargement } \\
\text { - Increased peak discharge due to an increase in impermeable } \\
\text { surfaces } \\
\text { - Lower water table causing dieback of stabilizing plants } \\
\text { - Reduced flood flow due to increased flow and plant cover } \\
\text { - Constrained flow and increased incision cause by erosion and } \\
\text { flood control efforts } \\
\text { - Decreased sediment-to-water ratio of floodwaters }\end{array}$ \\
\hline Gravel mining & $\begin{array}{l}\text { - Deposition caused by reduced gradient and flow expansion } \\
\text { - Upstream erosion at the vertical headwall of the site } \\
\text { - Increased sediment delivery downstream } \\
\text { - Decreased sediment-to-water ratio downstream, causing erosion } \\
\text { until enough sediment is recruited from the bed and banks to } \\
\text { offset the deficit } \\
\text { - Eventual widening of the incised arroyo and backfilling to the } \\
\text { original bed elevation }\end{array}$ \\
\hline Channelization & $\begin{array}{l}\text { - Increased stream velocity and slope } \\
\text { - Reduced hydraulic roughness } \\
\text { - Increased sediment transport and capacity, resulting in channel } \\
\text { incision } \\
\text { - Transport of excess sediment to unaltered reaches downstream, } \\
\text { causing aggradation and increased flooding }\end{array}$ \\
\hline Dam construction & $\begin{array}{l}\text { - Decreased peak flows downstream, sediment transport capacity, } \\
\text { and sediment-to-water ratio } \\
\text { - Loss of bank soil composition } \\
\text { - Channel incision downstream of dam } \\
\text { - Channel narrowing } \\
\text { - Sediment accumulation behind dam, raising channel's bed } \\
\text { elevation and potentially causing aggradation upstream }\end{array}$ \\
\hline Flow modifications & $\begin{array}{l}\text { - Increased base flow and channel vegetation caused by effluent } \\
\text { discharge } \\
\text { - Aggradation caused by surface water diversion or withdrawal } \\
\text { - Loss of riparian vegetation and channel instability caused by } \\
\text { groundwater extraction }\end{array}$ \\
\hline
\end{tabular}




\section{OHWM Delineation Background}

The OHWM is a defining element used to identify the lateral limits of nonwetland waters under Section 404 of the Clean Water Act (33 U.S.C. 1344). However, determining whether any particular water is a jurisdictional WoUS involves further assessment in accordance with the regulations, case law, and clarifying guidance. This manual addresses the identification of the OHWM in low-gradient, alluvial ephemeral/intermittent channels forms in the Arid West for use in the delineation of non-wetland waters.

\subsection{OHWM Indicators}

In dry-land fluvial systems typical of the Arid West, a clear natural scour line impressed on the bank, recent bank erosion, destruction of native terrestrial vegetation, and the presence of litter and debris are the most commonly used physical characteristics to indicate the OHWM (U.S. Army Corps of Engineers, South Pacific Division 2001). As part of an ongoing effort to refine OHWM indicators and delineation methods for ephemeral/intermittent channel forms, a list of potential OHWM indicators typically found below, at, and above the OHW boundary was developed by Lichvar and Wakeley (2004). The list includes both geomorphic (Table 5) and vegetation (Table 6) indicators, which are sorted by riparian wetness class. The geomorphic indicators listed in Table 5 are produced by a range of flow events and variable watershed conditions; not all indicators will be present in every channel. In addition to variation in indicator presence or absence from one channel to the next, there is also spatial and temporal variability of indicator position over the length of an individual channel and/ or laterally within the three zones (Fig. 13) identified by Lichvar and Wakeley (2004). Over the length of the channel and spanning the zones from below to above the OHW boundary, the geomorphic indicators themselves vary from weathering-related phenomena to relatively small-scale sedimentary structures to large-scale depositional/ erosional features (see Table 7 for examples). Correct delineation of OHW in Arid West channel forms depends on the proper identification of multiple geomorphic indicators when present and, when possible, the recognition of vegetative patterns and the distribution of specific species. 
Table 5. Potential geomorphic OHWM indicators categorized by location below, at, and above ordinary high water. (Modified from Lichvar and Wakeley 2004.)

\begin{tabular}{|l|l|l|}
\hline \multicolumn{1}{|c|}{ Below OHW } & \multicolumn{1}{|c|}{ At OHW } & \multicolumn{1}{c|}{ Above OHW } \\
\hline In-stream dunes & Valley flat & Desert pavement \\
Crested ripples & Active floodplain & Rock varnish \\
Flaser bedding & $\begin{array}{l}\text { Benches: low, mid, most } \\
\text { prominent } \\
\text { Harrow marks }\end{array}$ & Clast weathering \\
Gravel sheets to rippled sands & Salt splitting \\
Meander bars & Top of point bars & Carbonate etching \\
Sand tongues & Break in bank slope & Depositional topography \\
Muddy point bars & Upper limit of sand-sized particles & Caliche rubble \\
Long gravel bars & Soil development \\
Cobble bars behind obstructions & Staining of rocks \\
Scour holes downstream of obstructions & Exposed root hairs below intact \\
Obstacle marks & soil layer & Drainage development \\
Stepped-bed morphology in gravel & Surface relief \\
Narrow berms and levees & Silt deposits \\
Streaming lineations & Litter (organic debris, small twigs & \\
Dessication/mud cracks & and leaves) \\
Armored mud balls & Drift (organic debris, larger than \\
Knick points & twigs) & \\
\hline
\end{tabular}

Table 6. Potential vegetation OHWM indicators categorized by location below, at, and above ordinary high water (Lichvar and Wakeley 2004).

\begin{tabular}{|c|c|c|c|}
\hline & Below OHW & At OHW & Above OHW \\
\hline $\begin{array}{l}\text { Hydroriparian } \\
\text { indicators }\end{array}$ & $\begin{array}{l}\text { Herbaceous marsh species } \\
\text { Pioneer tree seedlings } \\
\text { Sparse, low vegetation } \\
\text { Annual herbs, hydromesic } \\
\quad \text { ruderals } \\
\text { Perennial herbs, hydromesic } \\
\quad \text { clonals }\end{array}$ & $\begin{array}{l}\text { Annual herbs, hydromesic } \\
\quad \text { ruderals } \\
\text { Perennial herbs, hydromesic } \\
\quad \text { clonals } \\
\text { Pioneer tree seedlings } \\
\text { Pioneer tree saplings }\end{array}$ & $\begin{array}{l}\text { Annual herbs, xeric ruderals } \\
\text { Perennial herbs, non-clonal } \\
\text { Perennial herbs, clonal and } \\
\text { non-clonal co-dominant } \\
\text { Mature pioneer trees, no } \\
\text { young trees } \\
\text { Mature pioneer trees w/ } \\
\text { upland species } \\
\text { Late-succesional species }\end{array}$ \\
\hline $\begin{array}{l}\text { Mesoriparian } \\
\text { indicators }\end{array}$ & $\begin{array}{l}\text { Pioneer tree seedlings } \\
\text { Sparse, low vegetation } \\
\text { Pioneer tree saplings } \\
\text { Xeroriparian species }\end{array}$ & $\begin{array}{l}\text { Sparse, low vegetation } \\
\text { Annual herbs, hydromesic } \\
\quad \text { ruderals } \\
\text { Perennial herbs, hydromesic } \\
\quad \text { clonals } \\
\text { Pioneer tree seedlings } \\
\text { Pioneer tree saplings } \\
\text { Xeroriparian species } \\
\text { Annual herbs, xeric ruderals }\end{array}$ & $\begin{array}{l}\text { Xeroriparian species } \\
\text { Annual herbs, xeric ruderals } \\
\text { Perennial herbs, non-clonal } \\
\text { Perennial herbs, clonal and } \\
\text { non-clonal codominant } \\
\text { Mature pioneer trees, no } \\
\text { young trees } \\
\text { Mature pioneer trees, xeric } \\
\text { understory } \\
\text { Mature pioneer trees w/ } \\
\text { upland species } \\
\text { Late-successional species } \\
\text { Upland species }\end{array}$ \\
\hline $\begin{array}{l}\text { Xeroriparian } \\
\text { indicators }\end{array}$ & $\begin{array}{l}\text { Sparse, low vegetation } \\
\text { Xeroriparian species } \\
\text { Annual herbs, xeric ruderals }\end{array}$ & $\begin{array}{l}\text { Sparse, low vegetation } \\
\text { Xeroriparian species } \\
\text { Annual herbs, xeric ruderals }\end{array}$ & $\begin{array}{l}\text { Annual herbs, xeric ruderals } \\
\text { Mature pioneer trees w/ } \\
\text { upland species } \\
\text { Upland species }\end{array}$ \\
\hline
\end{tabular}




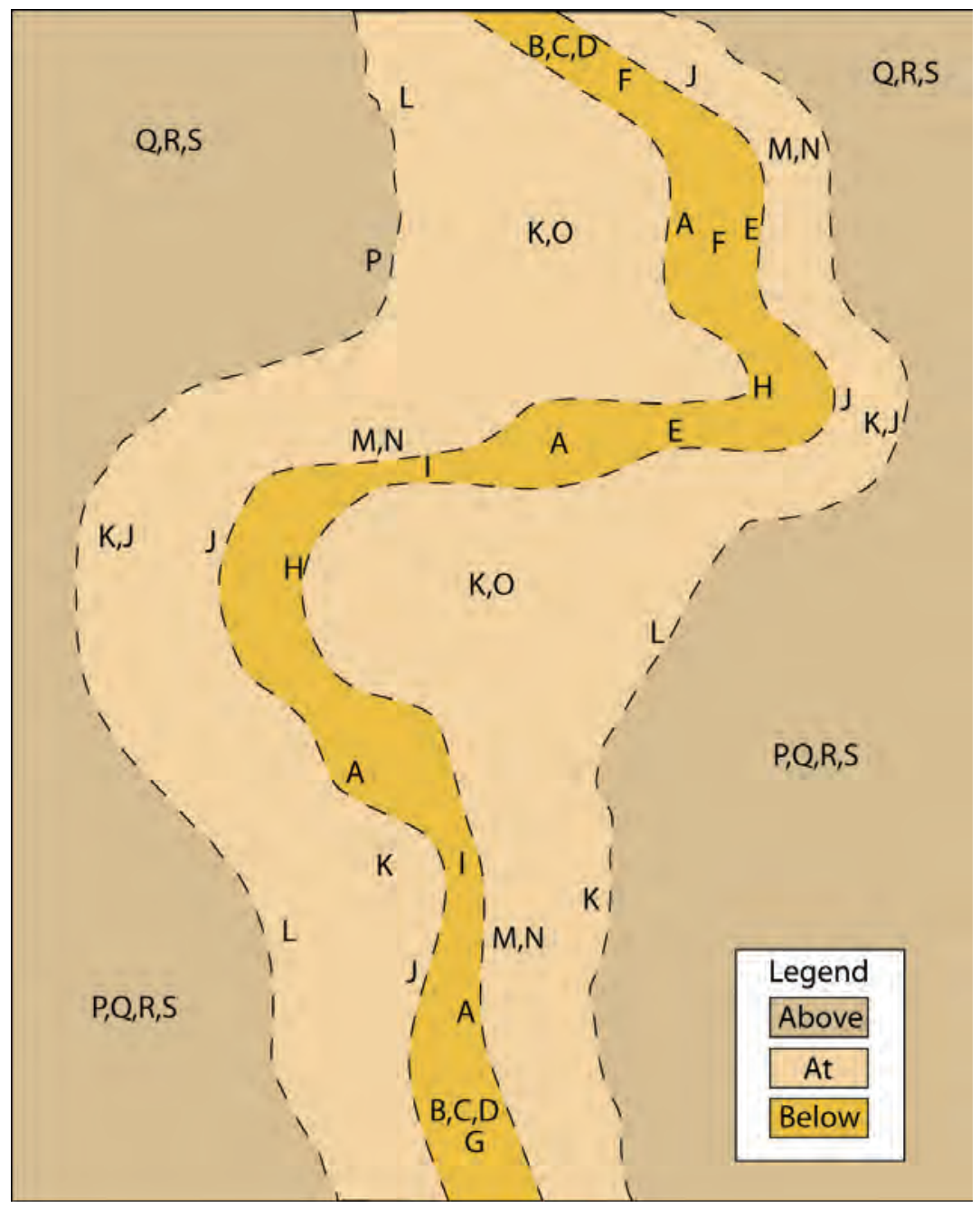

Figure 13. Lateral and longitudinal variability of geomorphic indicator position along a hypothetical Arid West channel form. The letters represent a potential locations for the corresponding indicator in Table 7 . Zones identified as below, at, and above the OHW boundary discussed in the text are color-coded and separated by dashed lines. 
Table 7. Select geomorphic OHWM indicators that may be present below, at, and above the OHW boundary.

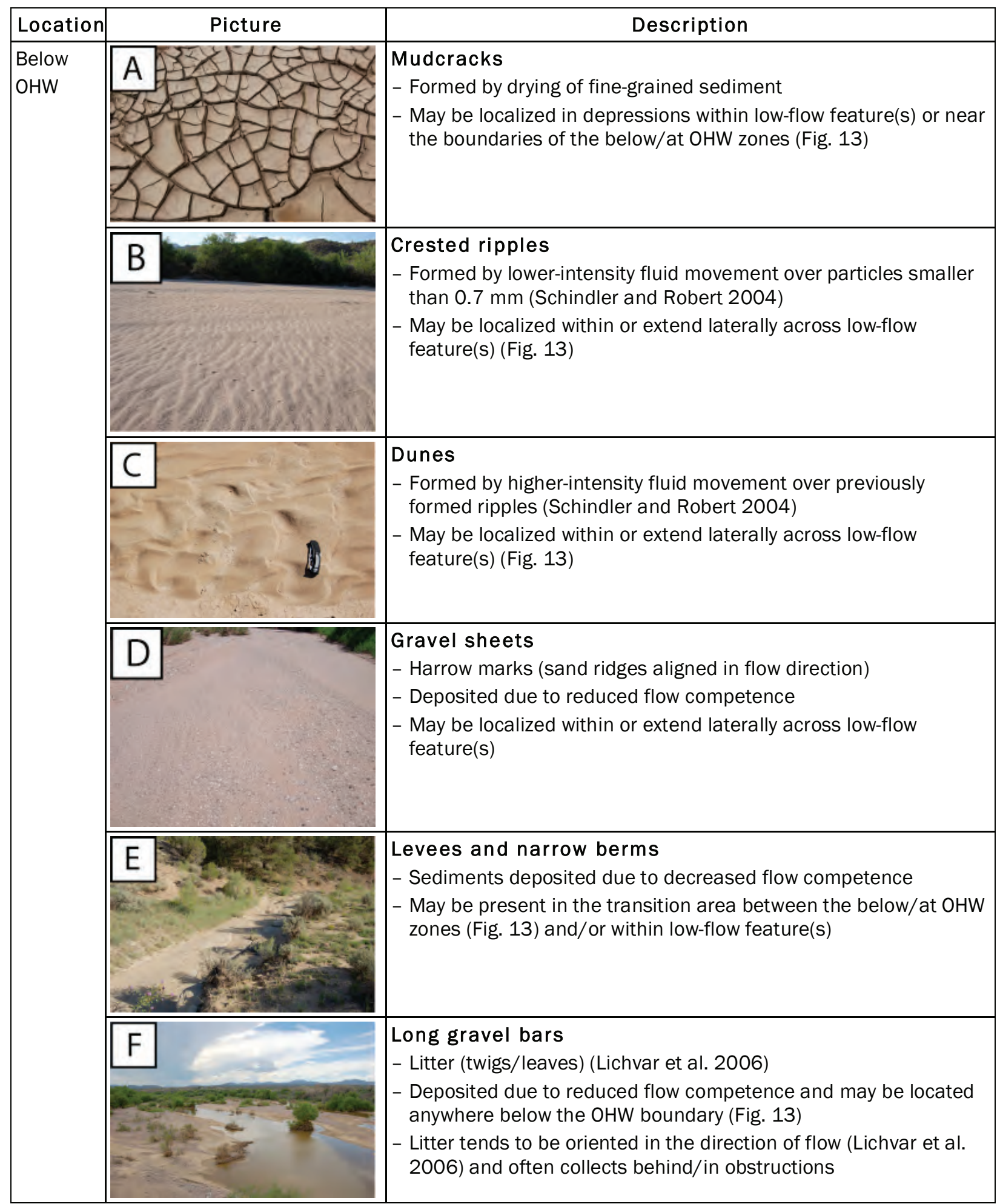




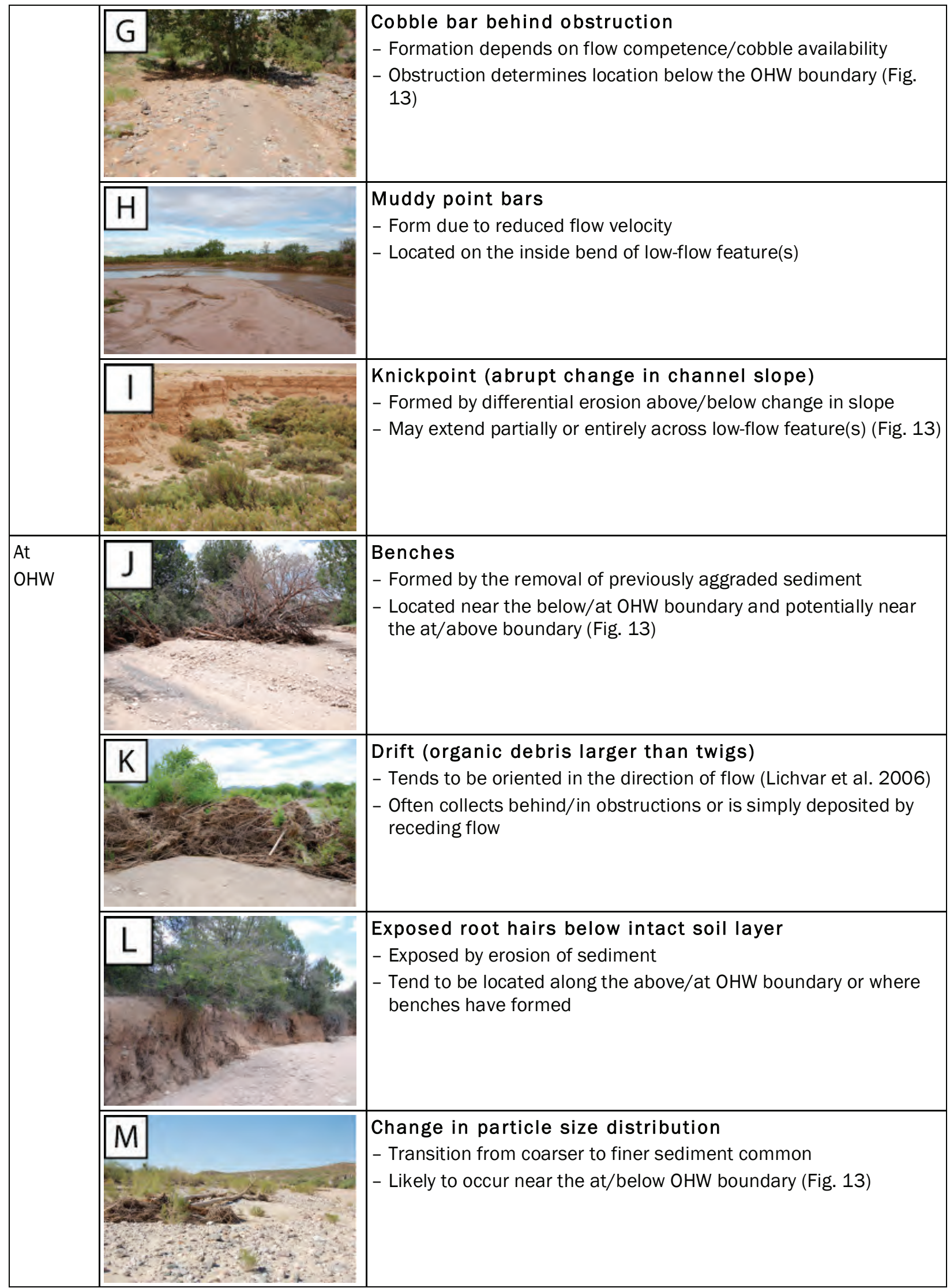




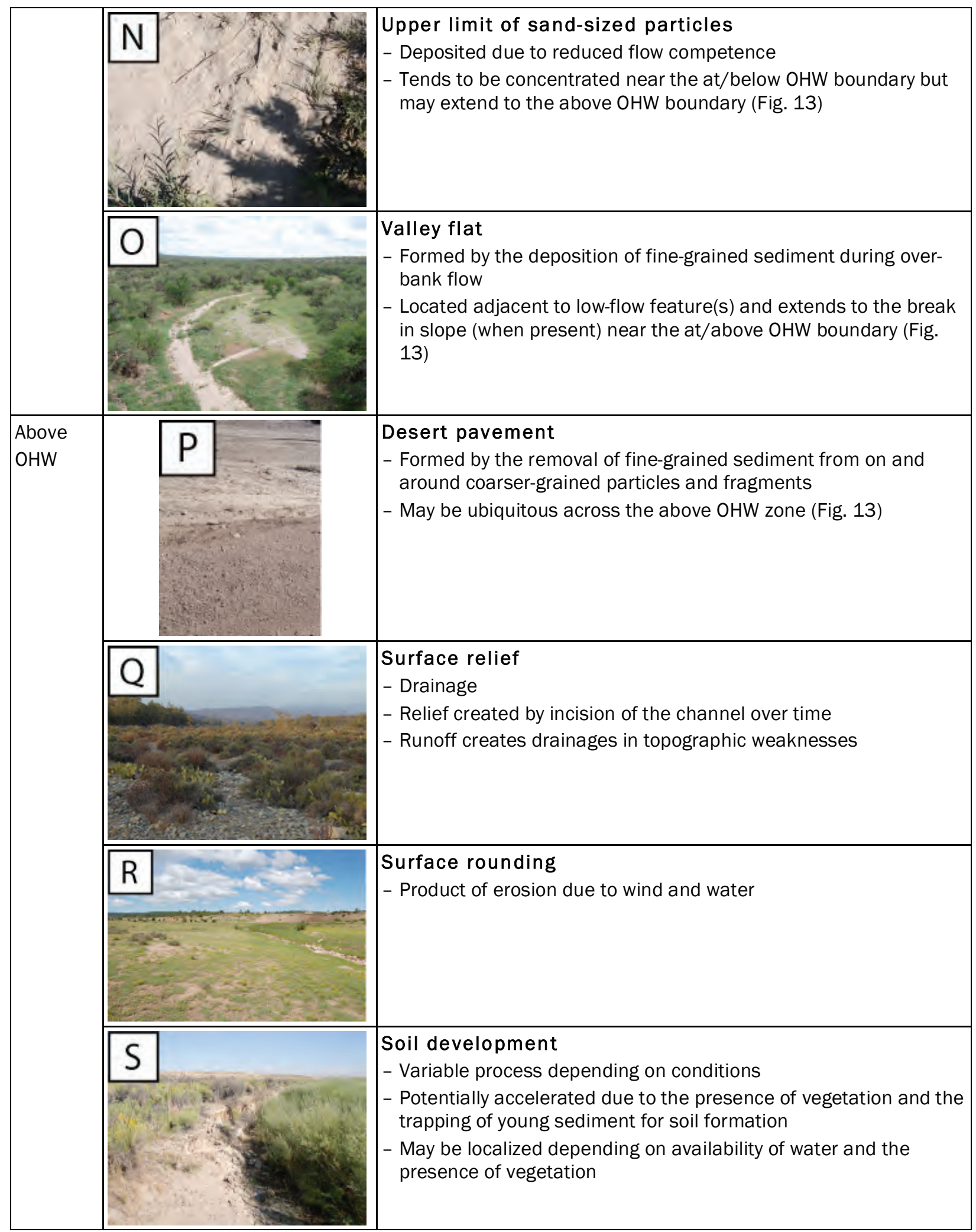


Vegetation patterns along arid channels are a function of many variables that range from the reach scale (effects of geology, floodplain soil chemistry, sediment particle size, etc.) (Lichvar and Wakeley 2004) to those that are influenced by the local landscape, which may vary laterally with distance from the center of the channel (lateral gradients in inundation duration and frequency, floodwater depth, etc.) (Stromberg 1993, 1998, Auble et al. 1994, Stromberg et al. 1996, Bendix 1999). Additionally, riparian plant community arrangements and distributions are controlled by local moisture availability and elevation, which are associated with increased precipitation, a higher abundance of vegetation, and the selection of certain assemblages and species (Lichvar and Wakeley 2004). Hydroriparian vegetation is predominantly found in areas that are perennially saturated or inundated, mesoriparian vegetation is typically present in areas that are seasonally moist, and xeroriparian vegetation is common in dry areas (Lichvar and Wakeley 2004). Vegetation variability associated with areas below, at, and above the OHW boundary is apparent in Table 8, which contains photographs and brief descriptions from a variety of channels in the Arid West. The presence of vegetation, like that of the geomorphic indicators discussed previously, may vary along the length of arid channel forms. Thus, when possible, the examination of both indicator types in tandem is necessary for the proper identification of OHW in Arid West channel forms. 
Table 8. Select vegetative OHWM indicators that may be present below, at, and above the OHW boundary.

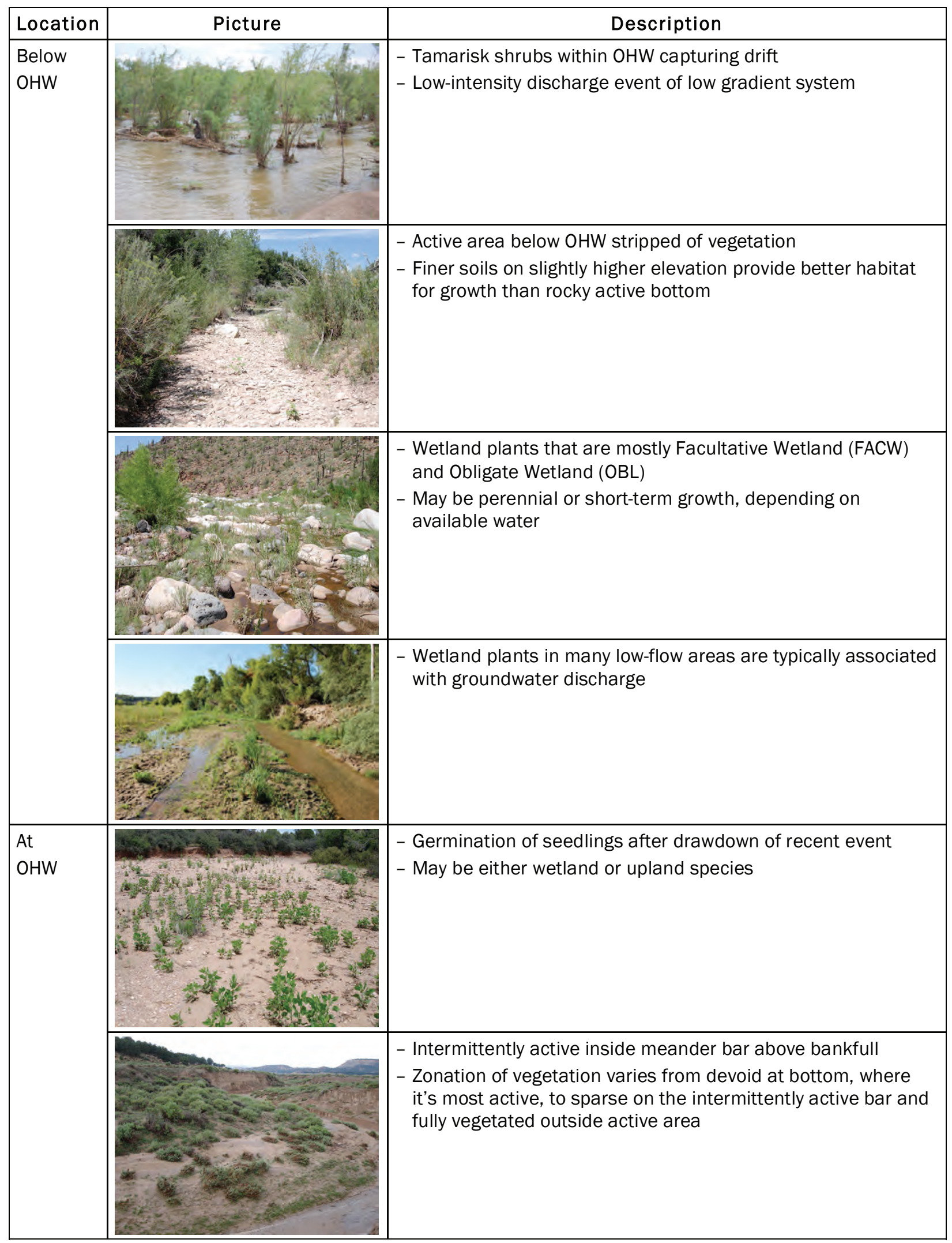




\begin{tabular}{|l|l|l|}
\hline & $\begin{array}{l}\text { - Most active area is barren in foreground } \\
\text { - Above OHW is a thick shrub zone in background lacking } \\
\text { physical removal from higher discharge events }\end{array}$ \\
\hline Above & & \\
OHW & $\begin{array}{l}\text { - Vegetation thickens above OHW zone due to lack of } \\
\text { disturbance from moderate events }\end{array}$ & \\
& & $\begin{array}{l}\text { - Old incised channel with active and bankfull zones } \\
\text { - Light green shrubs located on upper active zone } \\
\text { - Upper active zone maintained as evidenced by exposed soil } \\
\text { surfaces } \\
\text { - Majority of all events sizes retained within the incised } \\
\text { channel walls }\end{array}$ \\
\hline
\end{tabular}

\subsection{OHWM Indicator Distribution}

The traditional use of OHWM indicators to identify the limits of nonwetland waters is confounded in the Arid West by highly variable flow pathways within the channel. In an attempt to correlate OHWM indicators with flood return inundation levels, Lichvar et al. (2006) analyzed the distribution of indicators in several Arid West channels selected from a variety of test reaches. Long-term, continuous gage data and minimal anthropogenic influence were required for each watershed, and each test reach was mapped and divided into bankfull, active floodplain, and terrace floodplain hydrogeomorphic units to provide a means for the analysis of the distribution of the indicators (Lichvar et al. 2006). The mapped distribution of indicators for the Mission Creek study reach is shown in Figure 14, and the results of the statistical analysis of the indicators are shown in Figure 15. Contrary to expectations, the positions of the OHWM indicators are random, due to the coupling of variable pathways and repeating effective discharges. Driven by the lack of correlation between the distribution of OHWM indicators and flood return intervals (Fig. 15), Lichvar et al. (2006) proposed a conceptual model (Fig. 16, top) highlighting the influence of low to moderate events on the geometry of Arid West channel forms and the distribution of OHWM indicators. 


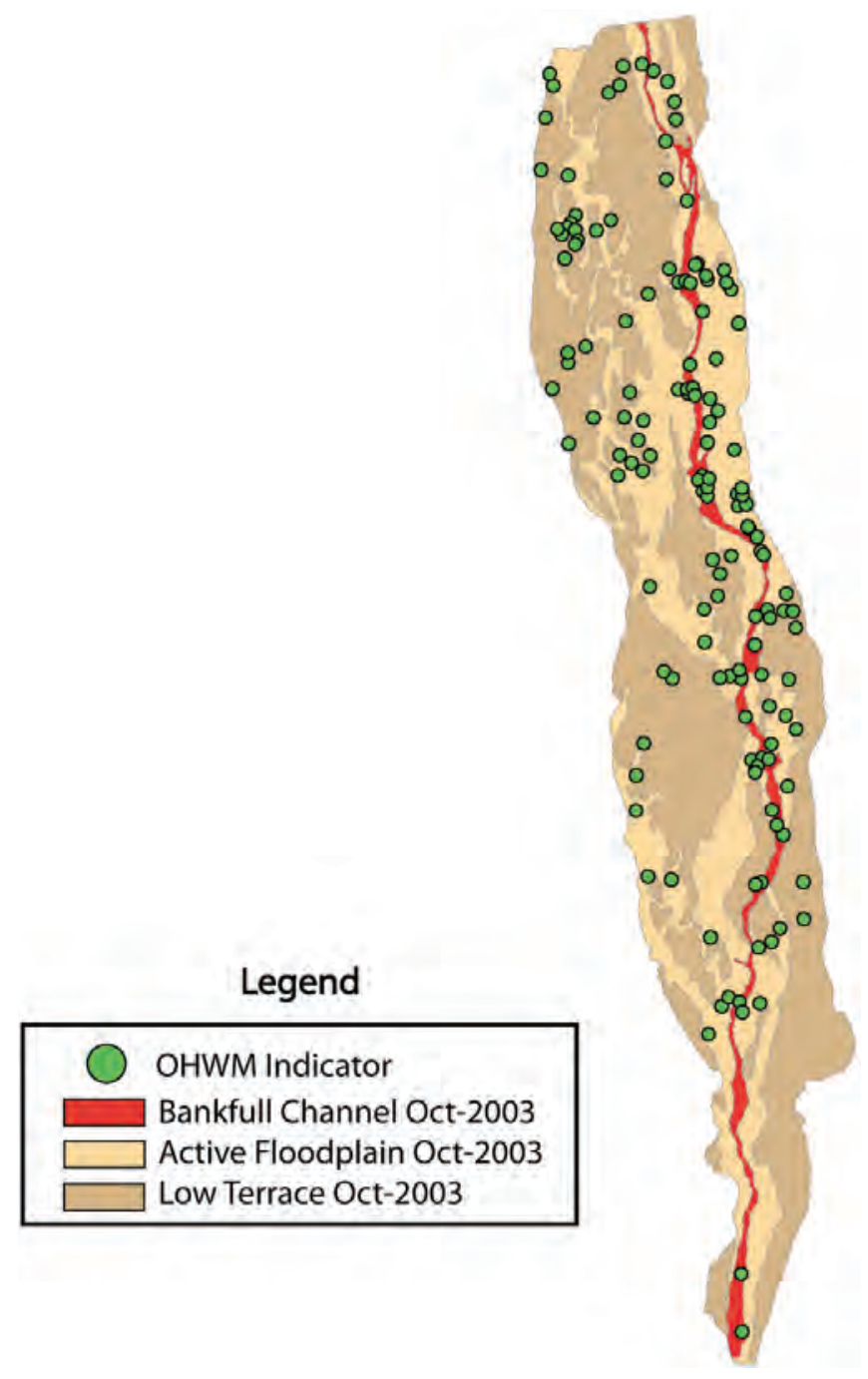

Figure 14. Hydrogeomorphic units and OHWM indicator positions within the Mission Creek study reach (Lichvar et al. 2006).

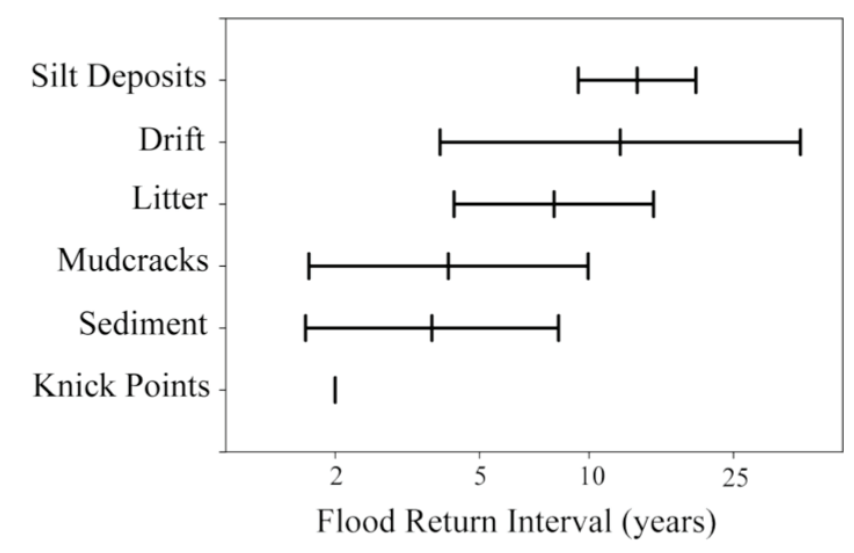

Figure 15. Mean \pm one standard deviation for each indicator type identified within the Mission Creek study reach. 


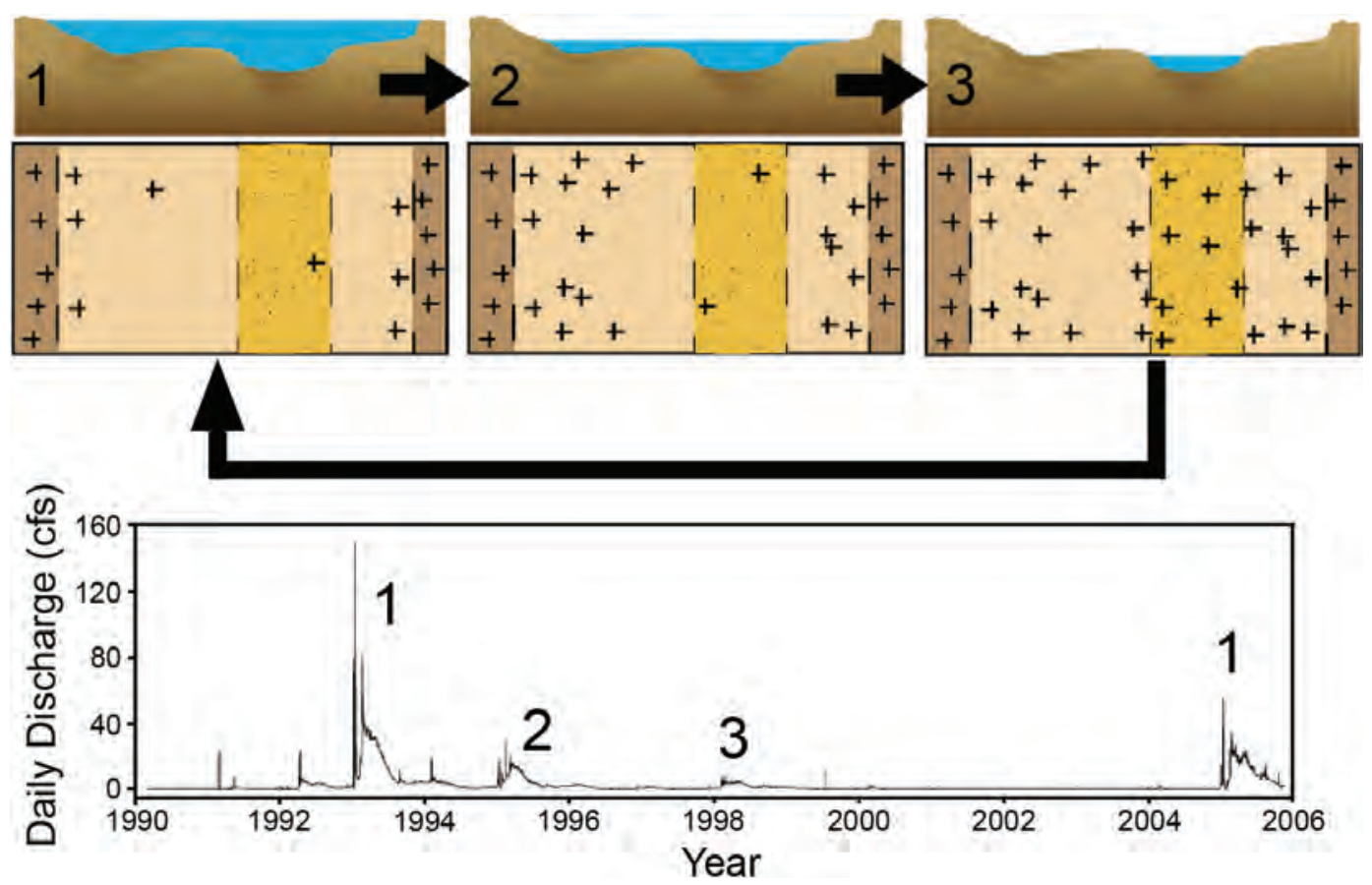

Figure 16. Conceptual model showing the locations of OHW indicators. The top diagram shows cross-sections and plan views of a channel for three discharge events. Blue indicates the maximum level of inundation per numbered event, dark yellow represents the bankfull zone, tan represents the active floodplain zone, brown represents the low terrace zone, and the plus signs indicate OHWM indicators. The bottom diagram is a flood hydrograph for Mission Creek covering 1990-2006. The events numbered on the hydrograph correspond to the conceptual events in the model. (Adapted from Lichvar et al. 2006.)

Below the model in Figure 16 is an actual flood hydrograph for Mission Creek. To illustrate the process of OHWM indicator (plus signs, analogous to the green dots in Figure 14) emplacement and formation, the numbered events on the hydrograph correspond to the numbers on each stage of the conceptual model. Immediately following a geomorphically effective discharge (1), OHWM indicators are predominantly concentrated near the margins of the affected area. Subsequent smaller discharge events (2 and 3) scatter OHWM indicators within or below the limits of the last geomorphically effective event (typically a low to moderate event). This condition persists until another effective discharge occurs, resulting in the removal of the majority of the indicators below the effective limits of the event. Event timing and magnitude vary from one system to another, so the three-stage concept depicted in Figure 16 is not representative of all channels. It is conceivable that an effective event could occur at any stage of the process, essentially "resetting" the system to near its original state, or perhaps several small discharge events might follow the initial geomorphically effective discharge, resulting in the formation of multiple low-flow features and the continued scattering of OHWMindicators. 
The model suggests that the location of traditional OHWM indicators is transitory, which is problematic for use in a regulatory program. Due to the inherent problems using OHWM indicators for delineating the boundaries of a non-wetland water, Lichvar et al. (2006) proposed using other features associated with the limits of the active floodplain to support the traditional OHWM indicators. The impact produced by geomorphically effective events renders the limit of the active floodplain the only repeatable feature that can be reliably used to delineate the position of a non-wetland water's OHWM. The active floodplain is easily identified in the field, less variable over time, and statistically linked to the hydrologic and hydraulic parameters of ephemeral/intermittent arid channel forms.

\subsection{Identification of the Active Floodplain}

As depicted in Figure 2, the active floodplain is the surface adjacent to and receiving frequent over-bank flow from the low-flow channel (Williams 1978, Rosgen 1996). In humid regions, the active floodplain is typically inundated during low to moderate (2- to 10-year recurrence) events (Riggs 1985) and is characterized by high-flow channels, generally unvegetated surfaces, and frequently a break in slope at either margin (Lichvar et al. 2006). However, modeling has shown that slightly larger events (5- to 10year recurrence) may be necessary to engage the active floodplain in arid systems (Lichvar et al. 2006). Areas within the active floodplain in lowgradient, alluvial ephemeral/intermittent channel forms typically have a reworked (naturally disturbed) appearance due to the impact of effective flood events, so proper identification of the active floodplain includes an awareness or knowledge of the timing of the most recent effective event. The frequent reworking of sediments within the active floodplain during such events often creates a contrast between areas within the active floodplain and the adjacent low terrace. The reworked appearance may be evident across the entire active floodplain, or it may be distributed among features that were not affected by the most recent effective event.

The limit of the active floodplain is indicated by textural and vegetative changes relative to the low terrace (Lichvar et al. 2006). The texture of the active floodplain is generally coarser than that of the low terrace (Fig. 17). The change in texture typically occurs as either a shift from sand in the active floodplain to a predominantly cobble matrix in the low terrace, or from a predominantly sand matrix in the active floodplain to silt in the low terrace. Vegetative changes include a shift in the dominant species, increasing or decreasing overall vegetative cover from the active floodplain 


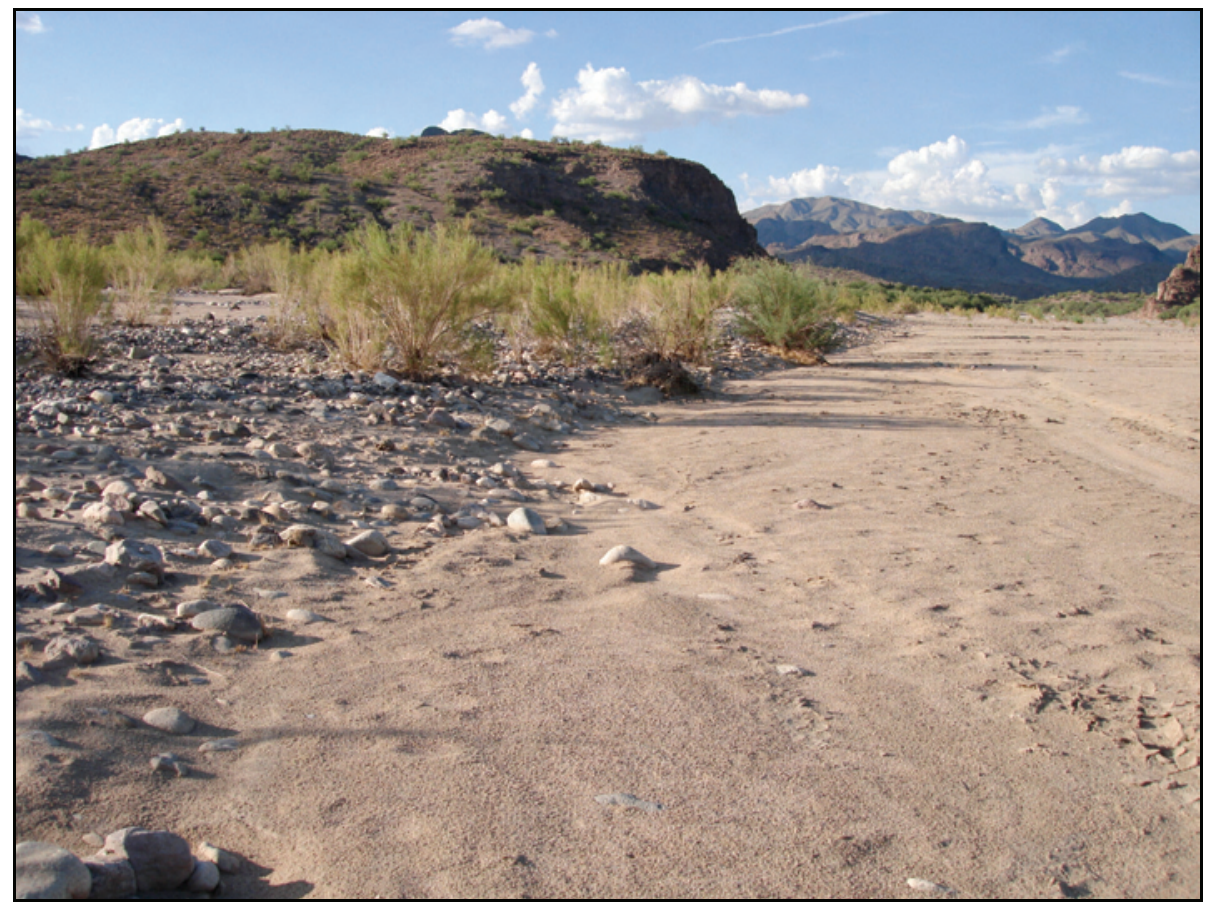

Figure 17. Active floodplain/low terrace boundary in an Arid West channel. Note the break in slope, the textural change from sandcobble in the low terrace to a finer-grained matrix within the active floodplain, and the increase in vegetative cover and maturity within the low terrace.

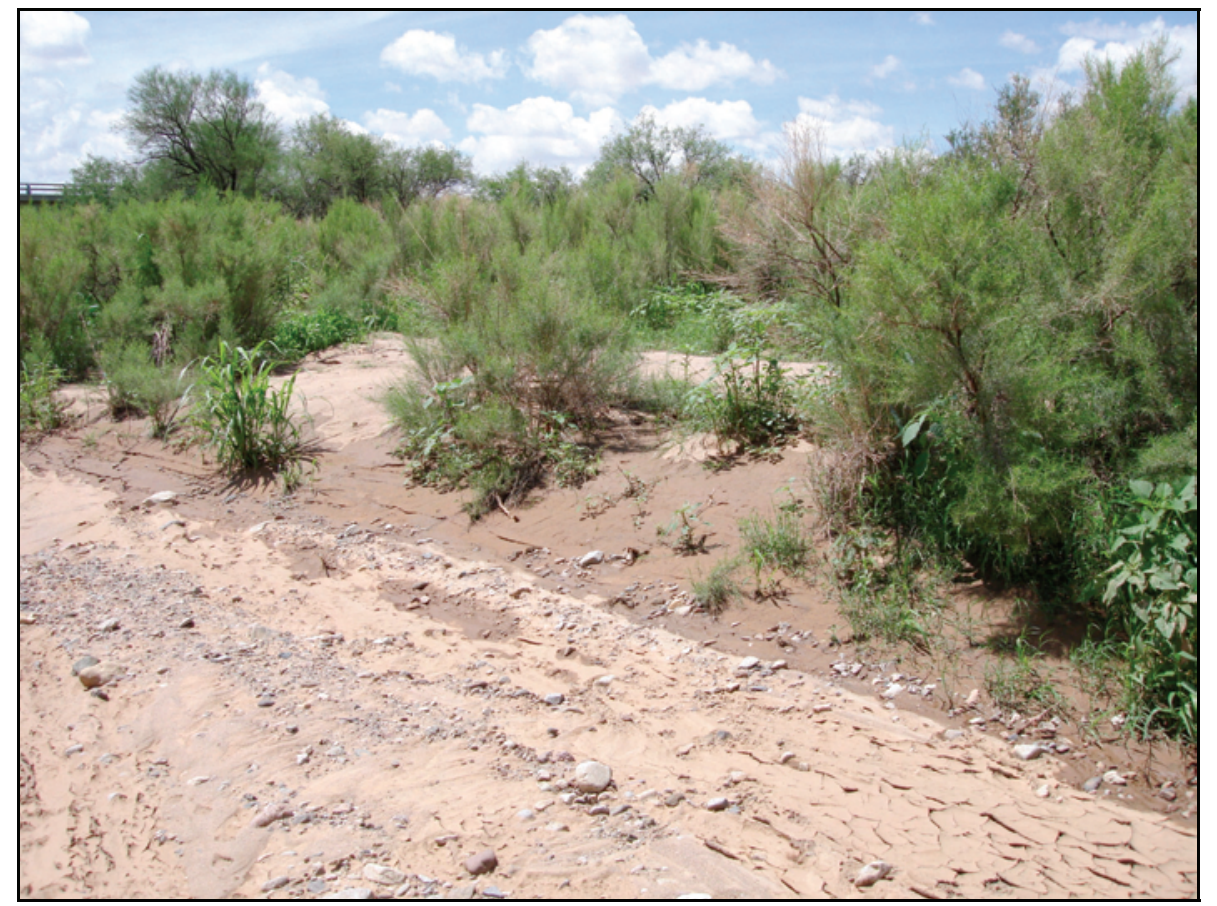

Figure 18. Vegetative shift at the active floodplain/low terrace boundary in an Arid West channel. 
The contrast between the active floodplain and adjacent terraces and uplands can vary depending on the influence of ground water on vegetation density. The examples shown in Figure 19 from Caruthers Creek, CA, and Deer Creek, CA, illustrate the potential lateral variability in vegetation density, which can be used as an aid in the identification of the active floodplain. At Caruthers Creek the active floodplain is much less vegetated than the surrounding, sparsely vegetated low terrace. At Deer Creek the circumstances are reversed; the vegetation density is highest in the active floodplain and decreases dramatically within the low terrace. In the examples from Figure 19, both the density and the distribution of vegetation across the channel may be controlled by the average annual precipitation. Deer Creek receives approximately 75\% more precipitation annually than Caruthers Creek. Also, Deer Creek is supported by ground water and is typically dry for only one month per year, while Caruthers Creek only flows in response to rainfall events.

\subsection{Arid West OHW - Active Floodplain}

The OHW zone in low-gradient, alluvial ephemeral/intermittent channel forms in the Arid West is the active floodplain. The dynamics of arid channel forms and the transitory nature of traditional OHWM indicators in arid environments render the limit of the active floodplain the only reliable and repeatable feature in terms of OHW delineation (Lichvar et al. 2006). In arid channel systems, the active floodplain functions in the same manner as the bankfull channel within a perennial channel form, in that most of the hydrological and fluvial dynamics produced by repeating effective discharges is confined within its boundaries. Also, the extent of flood model outputs for effective discharges-5- t0 10-year events in arid channels - aligns well with the boundaries of the active floodplain, and the characteristic vegetative behavior and sediment texture associated with the active floodplain/low terrace transition are readily observable in aerial photographs and in the field (Lichvar et al. 2006). 


\section{Caruthers Creek, CA}
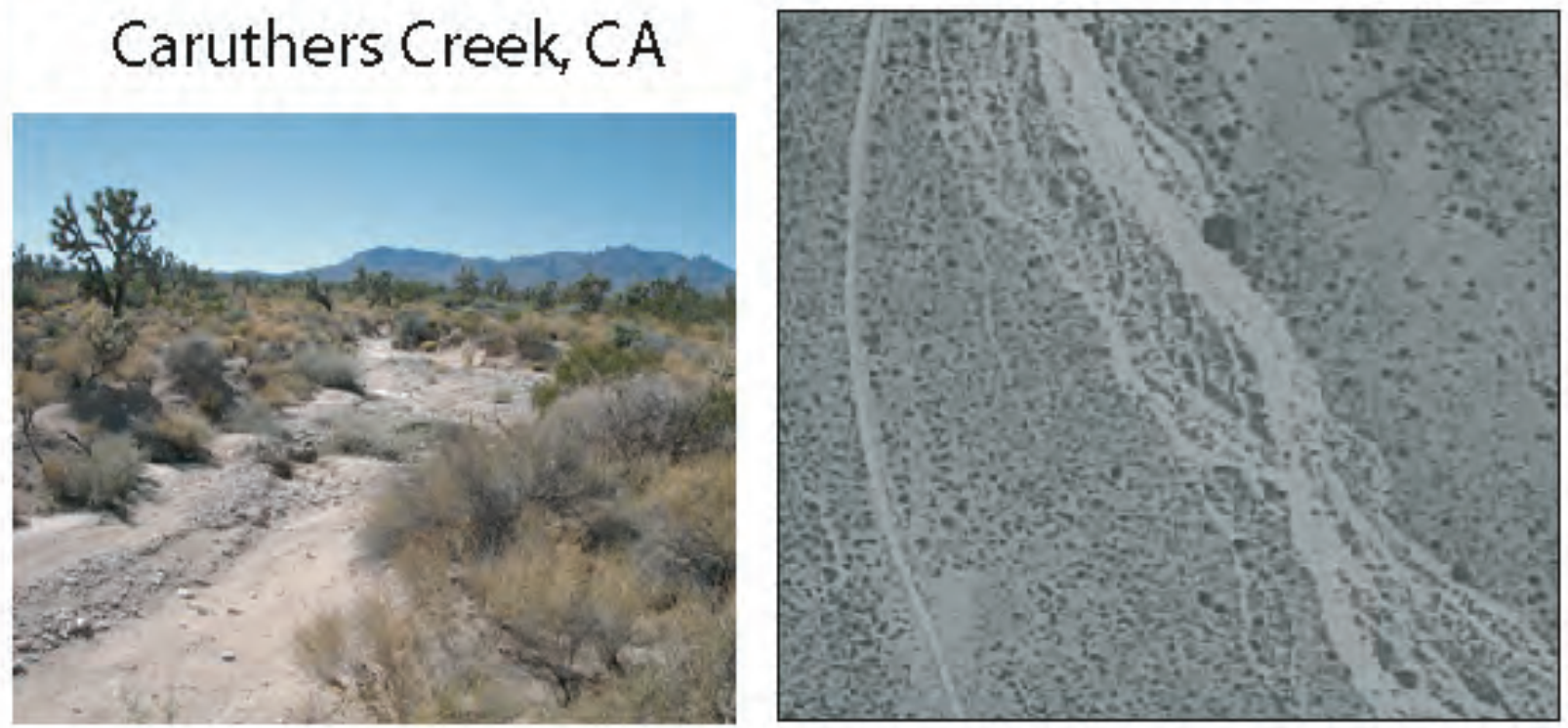

\section{Deer Creek, CA}
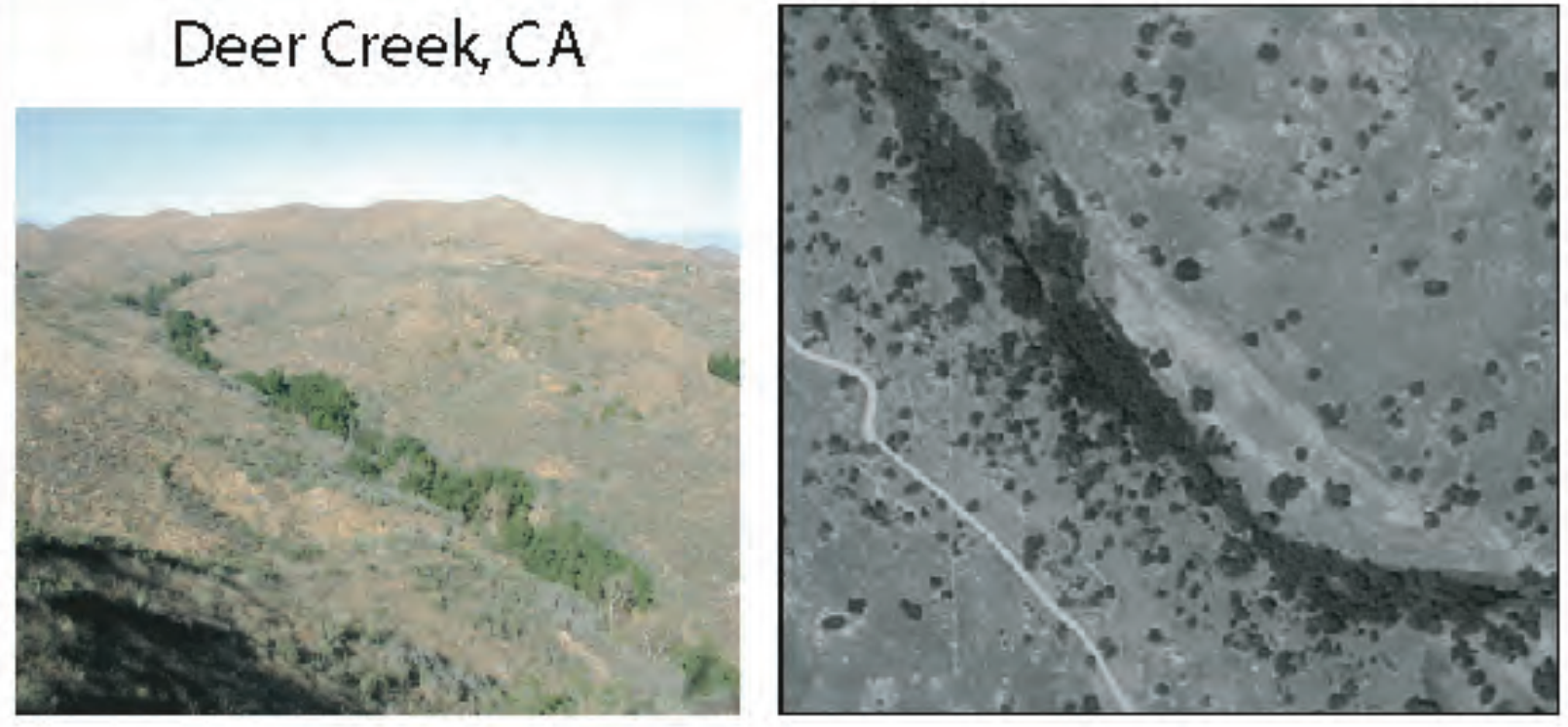

Figure 19. Examples of changes in vegetative cover and species between the active floodplain and the low terrace. 


\section{OHWM Identification Method}

The general approach discussed below is suggested for identifying the OHWM in low-gradient, alluvial ephemeral/intermittent channel forms in the Arid West for use in delineating the limits of non-wetland waters. Determining whether a water is a jurisdictional WoUS involves further assessment in accordance with the regulations, case law, and clarifying guidance. An identification occurs in two stages: (1) a preliminary delineation is made based on aerial photos, gage data (if available), and any other supporting information (e.g., topographic, soil, vegetation, and geologic maps; false color IR images; and rainfall data) that might be available for the area of interest, and (2) the limit of OHW is identified in the field using OHWM indicators and verified based on the preliminary delineation results.

\subsection{Resources Needed}

\subsubsection{Aerial Photography and Other Imagery}

Preferably, the delineation of the OHWM begins with an interpretation of aerial photographs of the area of interest (e.g., Fig. 20). Aerial photograph interpretation is suggested regardless of the size of the site.

The timing of the acquisition of the aerial photographs is important, so if a discharge history is available for the delineation site, aerial photographs should be obtained that were acquired following the most recent low to moderate (5- $10 \mathrm{yr}$ ) event if they are available. If not, photographs that were acquired following an older low to moderate event should be obtained, in addition to any more recent photographs that are available. Also, false color infrared images acquired over the area of interest may be used as a supplement to aerial photograph interpretations.

Contrasting patterns of vegetation and geomorphic features that are related to breaks in slope and are associated with the active floodplain and low terrace zones of a channel cross-section can typically be interpreted directly from aerial photographs and other types of remotely sensed imagery. Textural changes associated with the reworked appearance of the active floodplain must be inferred based on lateral variability in color (tone) and brightness within the channel cross-section. It is these three 


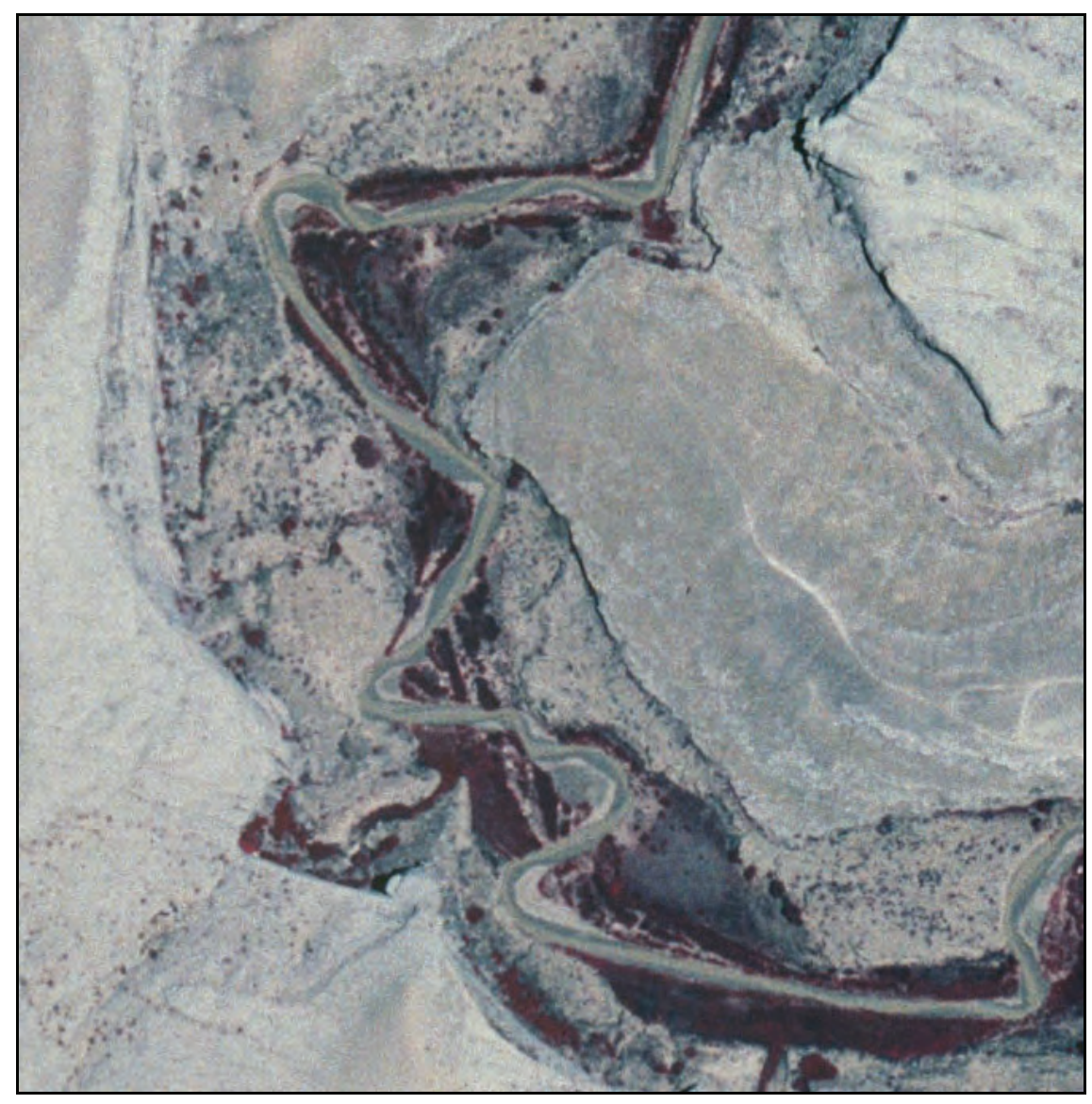

Figure 20. Aerial photograph acquired over Chinle Creek, AZ.

variables - vegetation density, breaks in slope, and texture associated with reworked materials - that are used to make a preliminary identification of the limits of the active floodplain.

Preliminary mapping can be done either on paper using the photographs as a base or on a digital file using GIS software. When available, stereo pairs should be utilized to determine subtle topographic variation within the area of interest. The photograph resolution should be sufficient to detect the smallest feature of interest; a minimum mapping scale of 1:24,000 is suggested to retain the necessary information for a preliminary delineation. Aerial photography, which may be obtained from in-house holdings, local governments, various federal agencies, and the Internet (Table 9), can also be used to establish the types of features that are present, both upstream and downstream of the site, that may influence interpretation of the site dynamics. 
Table 9. Websites with access to digital imagery.

\begin{tabular}{|l|l|}
\hline Coverage & \multicolumn{1}{|c|}{ Website } \\
\hline AZ & http://aria.arizona.edu/ \\
\hline CA & http://gis.ca.gov/data.epl \\
\hline ID & http://giscenter.isu.edu/data/index.htm \\
\hline NM & http://rgis.unm.edu/intro.cfm \\
\hline NV & http://keck.library.unr.edu/datawarehouse.html \\
\hline OR & http://www.oregon.gov/DAS/EISPD/GEO/data/doq.shtml \\
\hline TX & http://www.tnris.state.tx.us/stratmap/doq.htm \\
\hline UT & http://agrc.utah.gov/agrc_sgid/sgidintro.html \\
\hline WA & http://gis.ess.washington.edu/data/raster/index.html \\
\hline WY & http://wgiac.state.wy.us/html/aboutDoqq2002.asp \\
\hline National & http://datagateway.nrcs.usda.gov/ \\
\hline National & http://worldwind.arc.nasa.gov/index.html \\
\hline National & http://www.terraserver.com/ \\
\hline National & http://store.usgs.gov/ \\
\hline
\end{tabular}

\subsubsection{Topographic Maps}

Topographic maps (e.g., Fig. 21) are useful in interpreting the influence of the surrounding landscape on the delineation location. They show both natural and anthropogenic influences on the area and can also be used as a guide for orientation within the area. Topographic maps, like aerial photographs, can be obtained from in-house holdings, local governments, various federal agencies, and the Internet. Many are available digitally at no cost at the websites listed in Table 9. 


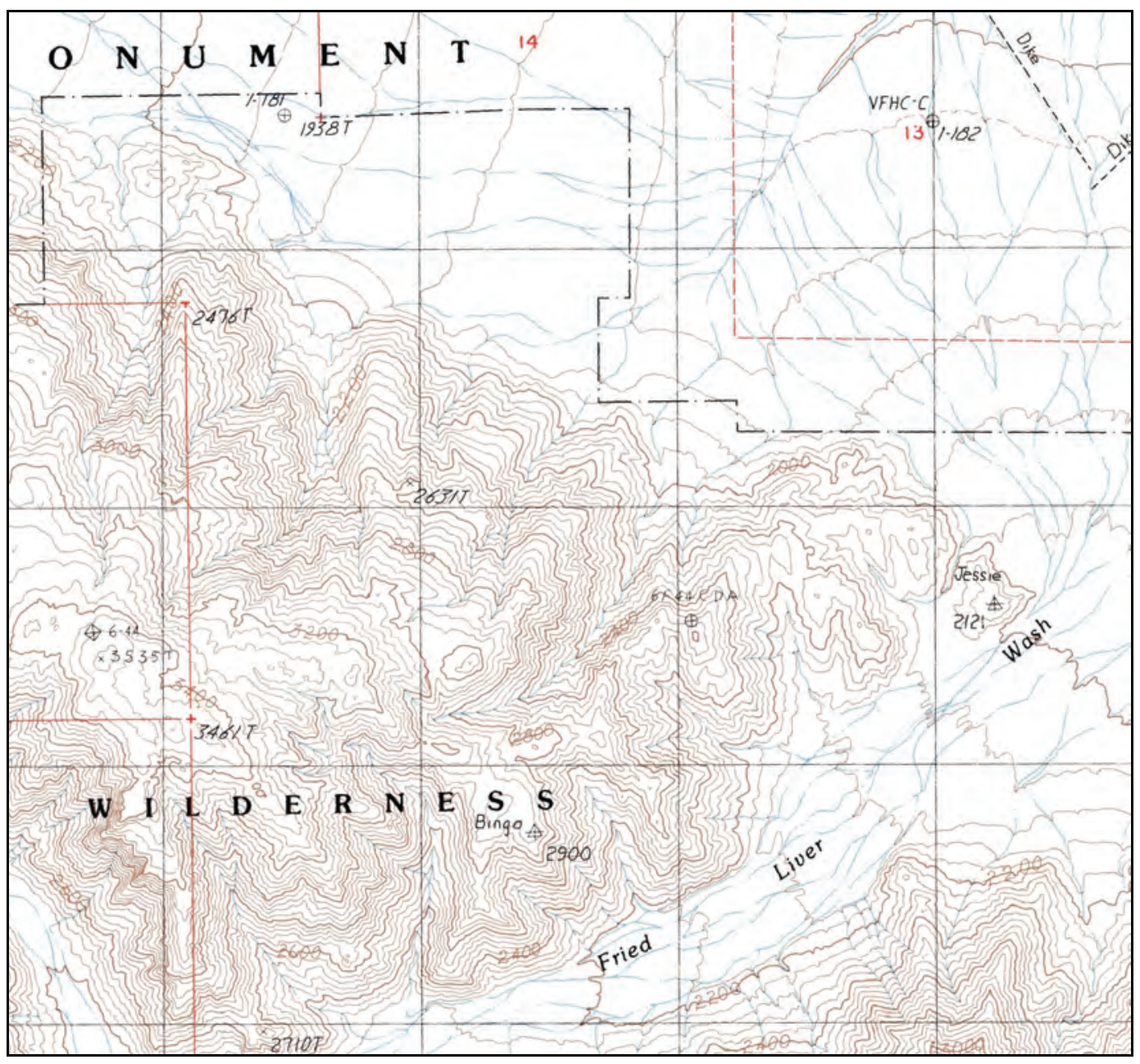

Figure 21. Section of a topographic map of the Fried Liver Wash Quadrangle, CA. The map scale is $1: 24,000$, and the topographic contour interval is $40 \mathrm{ft}$.

\subsubsection{Other Maps}

Geologic, vegetation, and soils maps, when available, provide an opportunity to gain a deeper understanding of not only the delineation site, but also the watershed that influences it. Although supplemental maps are not required for a preliminary delineation, preliminary interpretations may be more precise and the potential complexity of field delineations can be reduced if all available resources are utilized.

Geologic maps (e.g., Fig. 22) provide information regarding geologic controls and alluvial materials present at the delineation site, and, based on the broader geology of the watershed, inferences can be made regarding the availability and types of sediment that may be transported within the channel during flow events. Based on the geologic map interpretations, it may be possible to draw conclusions regarding geomorphic features of 


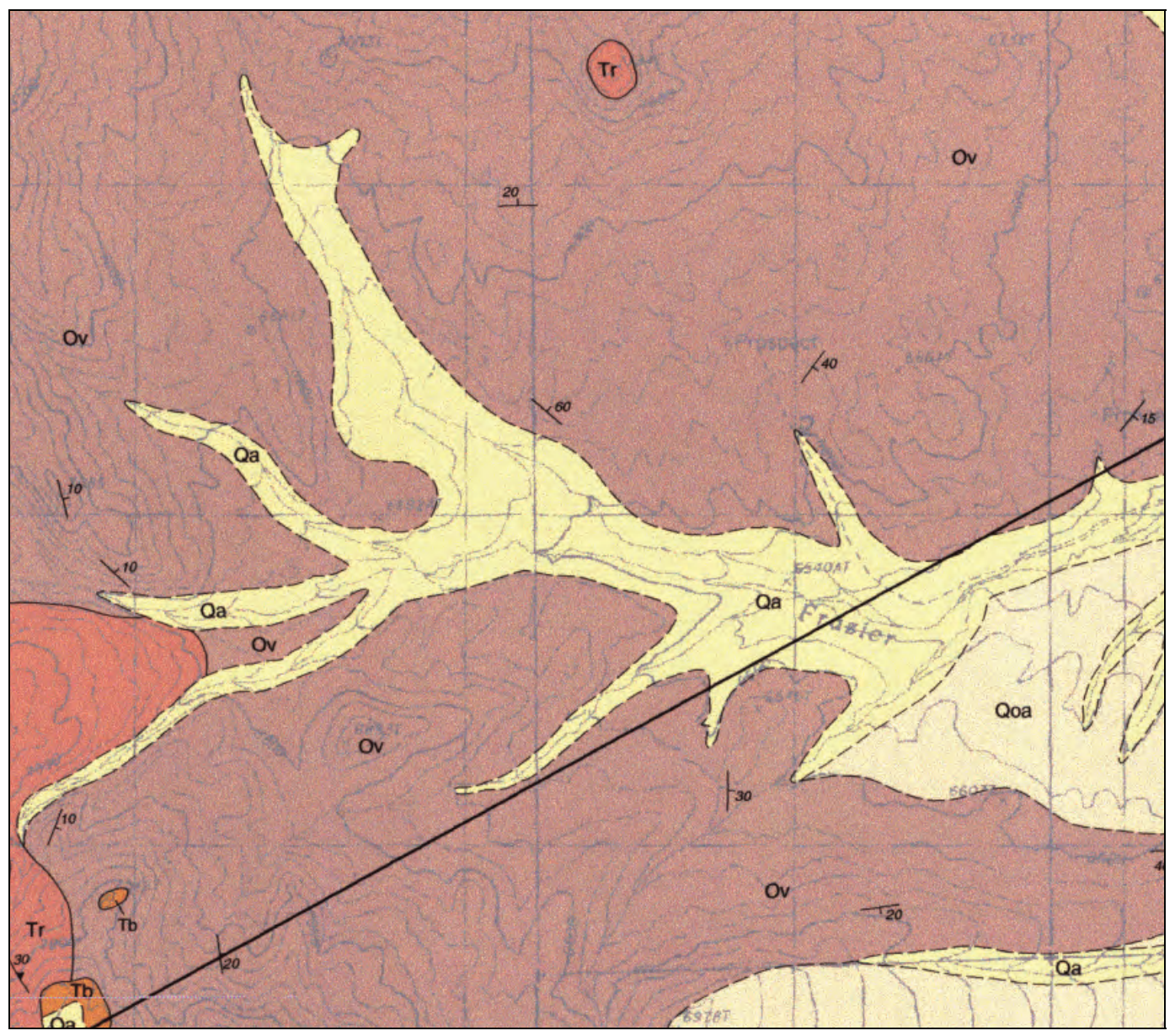

Figure 22. Section of a geologic/topographic map of the Frazier Creek Quadrangle, NV. Each geologic unit is designated by a color and symbol. The map scale is $1: 24,000$, and the topographic contour interval is $40 \mathrm{ft}$.

interest for the both the preliminary delineation and the on-site delineation in the field, such as breaks in slope associated with the active floodplain/low terrace boundary. Also, inferences may be made regarding other types of OHWM indicators (geomorphic and vegetative) that may be useful when determining the limit of $\mathrm{OHW}$ in the field.

Vegetation maps (e.g., Fig. 23) provide information regarding the distribution of plant communities in the vicinity of the delineation site, as well as within the watershed. Interpretations of vegetation maps may provide insight into bank stability, sediment storage along a channel, input of sediment to the system, and, possibly, input of groundwater to the system. It is important to understand bank stability, sediment storage, and sediment input to the system when evaluating geomorphic features such as breaks in slope associated with the active floodplain/ low terrace boundary and when determining the other types of OHWM indicators that 


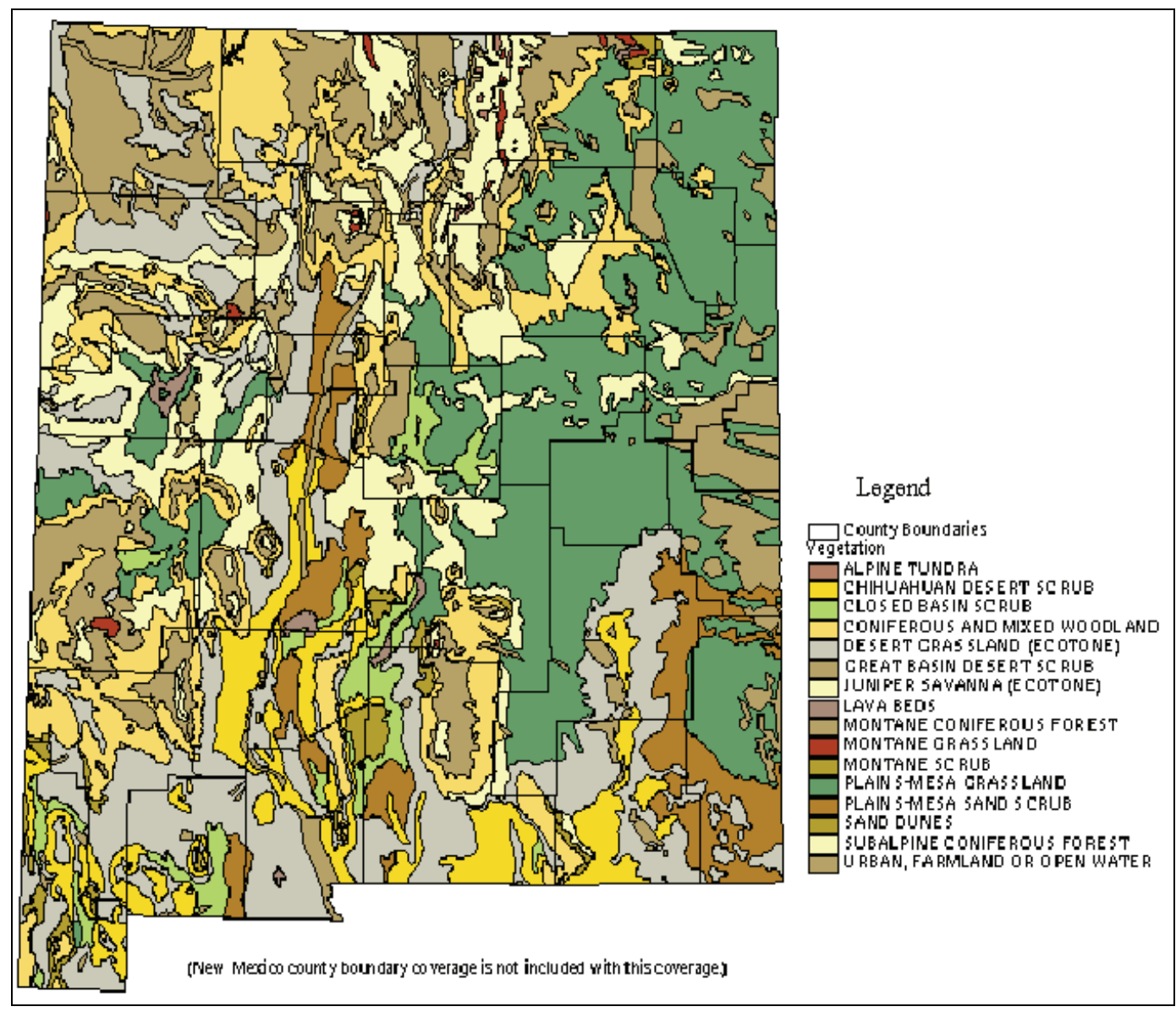

Figure 23. General vegetation map of New Mexico. The map illustrates the distribution of plant communities across the entire state.

may be present at the site. Groundwater input to the system is pertinent when interpreting vegetation density associated with a particular zone of a channel cross-section in both the preliminary procedure and during the on-site procedure in the field.

Soils maps (e.g., Fig. 24) provide information regarding the distribution of soil types within the area of interest. Typically, Arid West stream channels lack soil profile features associated with hydric soils. Preliminary interpretations of the soil types present at a delineation site may reveal areas of relative stability (mature soils) within the channel cross-section, which often indicate the repeated or long-term presence of water. Both factors - mature soil and the presence of water - contribute to the density and distribution of vegetation, which is often related to bank stability, and therefore, the potential presence of a break in slope. Also, an understanding of the distribution of soils within the area of interest may reduce the complexity of textural interpretations based on aerial photograph analysis. 


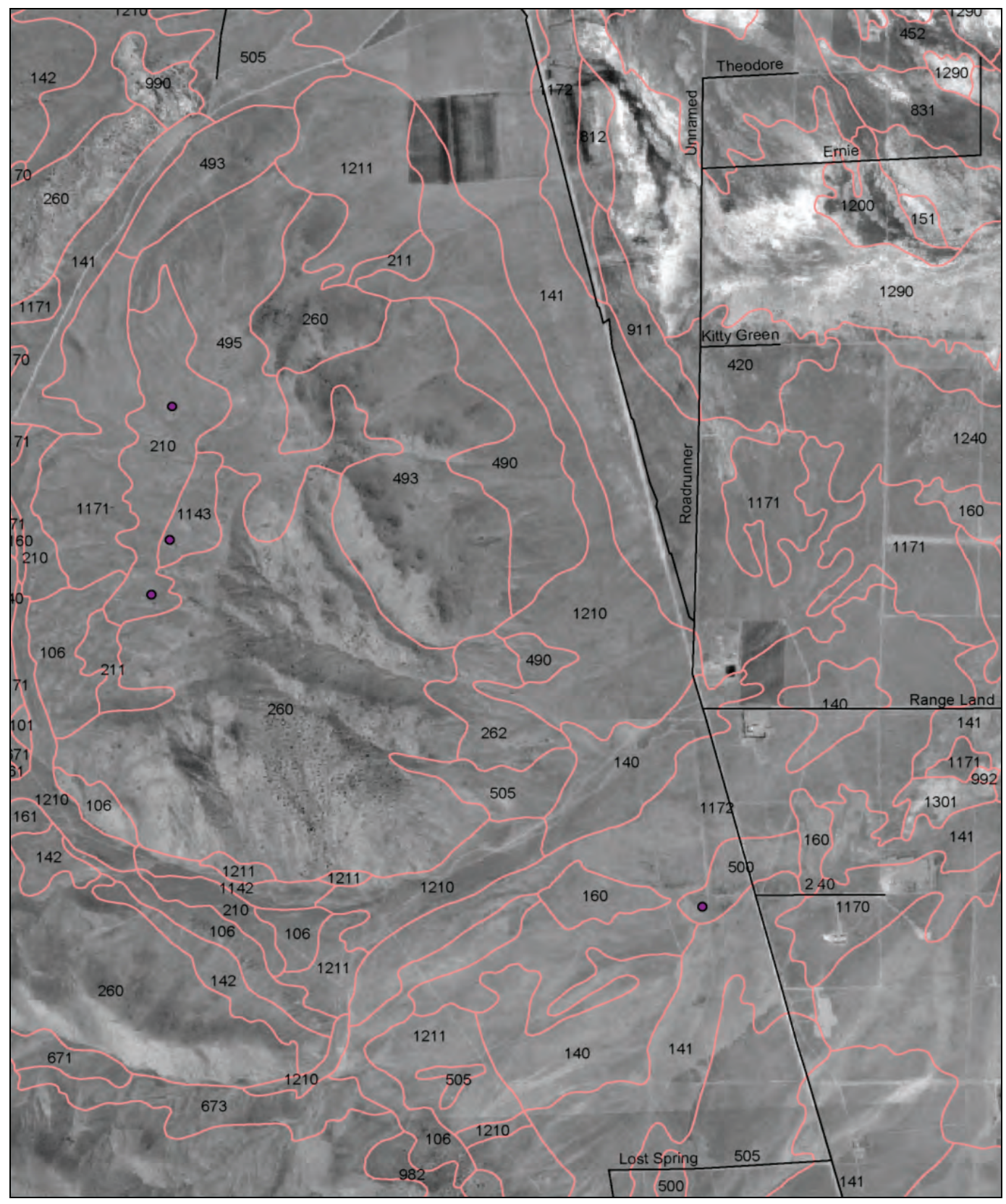

Figure 24. Section of a soils map of the Frasier Flat Quadrangle, NV. Soil types are numbered and separated by boundaries.

\subsubsection{Rainfall Data}

The timing of the most recent low to moderate events within a system of interest may be inferred from rainfall data (Fig 25). Rainfall data, when available, should be analyzed prior to obtaining the aerial photographs for delineation purposes, so that the inferred timing of low to moderate flow events is taken into consideration when determining the necessary acquisition dates of the photographs. 


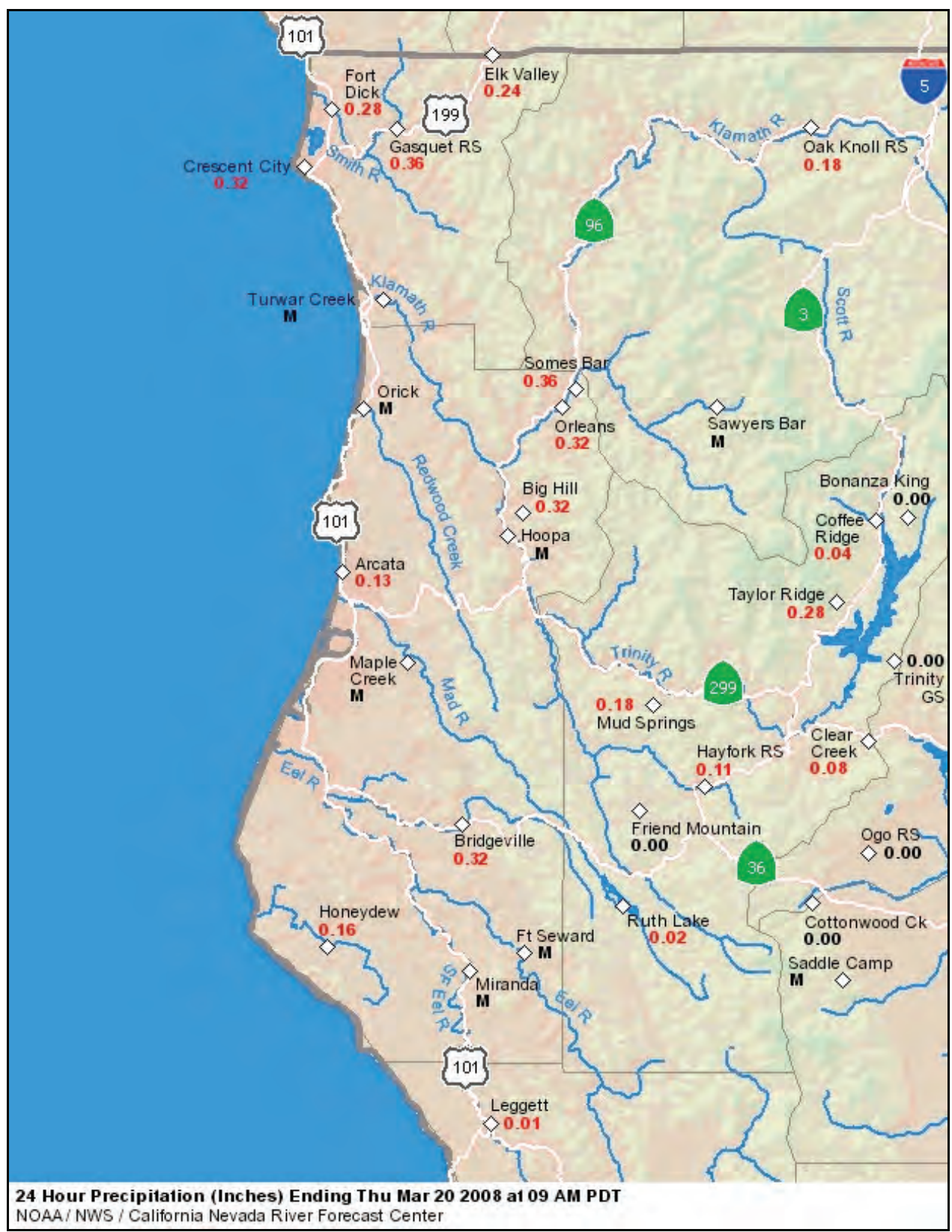

Figure 25. Distribution of precipitation over a portion of northern California.

\subsubsection{Stream Gage Data}

If a stream gage is present, the gage data should be obtained to determine recent discharge history. The gage data may be comprehensive enough to perform an annual peak flood frequency analysis in accordance with Bulletin 17B Guidelines (Interagency Advisory Committee on Water Data 1982). The USGS maintains a database of stream flow obtained from stream gages across the country. This is available online at http:// nwis.waterdata.usgs.gov/nwis/sw. Various local and federal 
agencies maintain stream gage networks and should be contacted to determine if gages are present. If stream gages are not present in the channel of interest, visit http:/ / water.usgs.gov/ osw/ programs/ nss/ index.html to determine if regression equations have been developed either for the entire state where the stream is located or for individual regions within the state to allow the user to transfer data from gaged systems to ungaged systems that are similar in nature. Regression curves produced by gage data acquired from other streams near the area of interest should be used with caution when inferring the recent discharge history for the stream of interest. If gage data are available for the stream reach of interest, a clinometer or level will be needed in the field.

\subsubsection{Existing Delineations}

If the site to be delineated has previously been delineated for OHWM, then the existing delineation(s) should be reviewed. Due to the dynamic nature of Arid West channel forms, changes that may have occurred within the channel may be significant enough to warrant reconsideration of the OHW limits.

\subsection{Preliminary Delineation Procedure}

Gather all available resources discussed in Section 3.1 for the area to be delineated. If stream gage data are available for the stream reach of interest, perform ALL steps in this section and then proceed to Section 3.3. If no hydrologic data are available, perform only STEP 1 and then proceed to Section 3.3 (Field Verification of Preliminary Delineation).

1. Analyze the aerial photographs (and any additional materials that were obtained) to identify differences in vegetative cover, areas that appear to have been reworked, and the presence of breaks in slope that may be associated with the active floodplain/low terrace boundary. Either digitally or manually (on a paper photograph), map the interpreted limits of the active floodplain within the delineation site at a minimum scale of 1:24,000.

Gage data provide additional information regarding the recent discharge history for the channel of interest. They should be used when possible to aid in determining a site's current condition relative to the cyclic flood/channel response cycle and to provide additional support in identifying the low to moderate peak flow events associated with the extent of OHW. The gage data and other parameters determined or 
inferred from them will be most accurate near the gage where they were collected. As distance increases either above or below the gage location, the use of physical evidence to identify the limit of OHW is emphasized. In some cases, as distance increases from the gage, the nature of the channel may not change and the physical evidence associated with the limit of OHW identified near the gage will be representative of the limit identified either below or above the gage location. However, it should never be assumed that the relationships determined at the gage will be valid at other positions along the channel.

2. Download and use a software package (e.g., HEC-SSP) to perform an annual peak flood frequency analysis (FFA) following Bulletin 17B guidelines (Interagency Advisory Committee on Water Data 1982) (Fig. 26). Please note that a user's manual containing all of the pertinent information for the HEC-SSP software is downloaded at the time of the software acquisition (http:// www.hec.usace.army.mil/ software/ hecssp/index.html).

3. From the FFA results, determine the discharge (cfs) for 2-, 5-, 10-, and 25-year events at the gage of interest. The probability of each event is $0.5,0.2,0.1$, and 0.04 , respectively (Fig. 27).

4. For real-time gages (those accessible via http:/ / waterdata.usgs.gov/ nwis/rt) within CA, CO, NV, OR, or ID, download and save the most current shift-adjusted rating curve from the station's real-time data webpage. For real-time gages elsewhere, or for non-real-time gages, contact the state USGS Water Resources district and request the gage station's most current shift-adjusted rating.

5. Examine the recent discharge history including annual peak flow reconds obtained via the Internet (http:/ / waterdata.usgs.gov/ nwis/ sw) and determine the discharge value that is associated with the most recent event exceeding a 5-year event, as well as the amount of time that has elapsed since the most recent event exceeding a 5-year event (Fig. 28).

6. Using the most recent shift-adjusted rating curve, determine the stage heights (see note below) associated with discharges for the 2-, 5-, 10-, and 25-year events and the most recent event that exceeds a 5-year event (Fig. 29). 


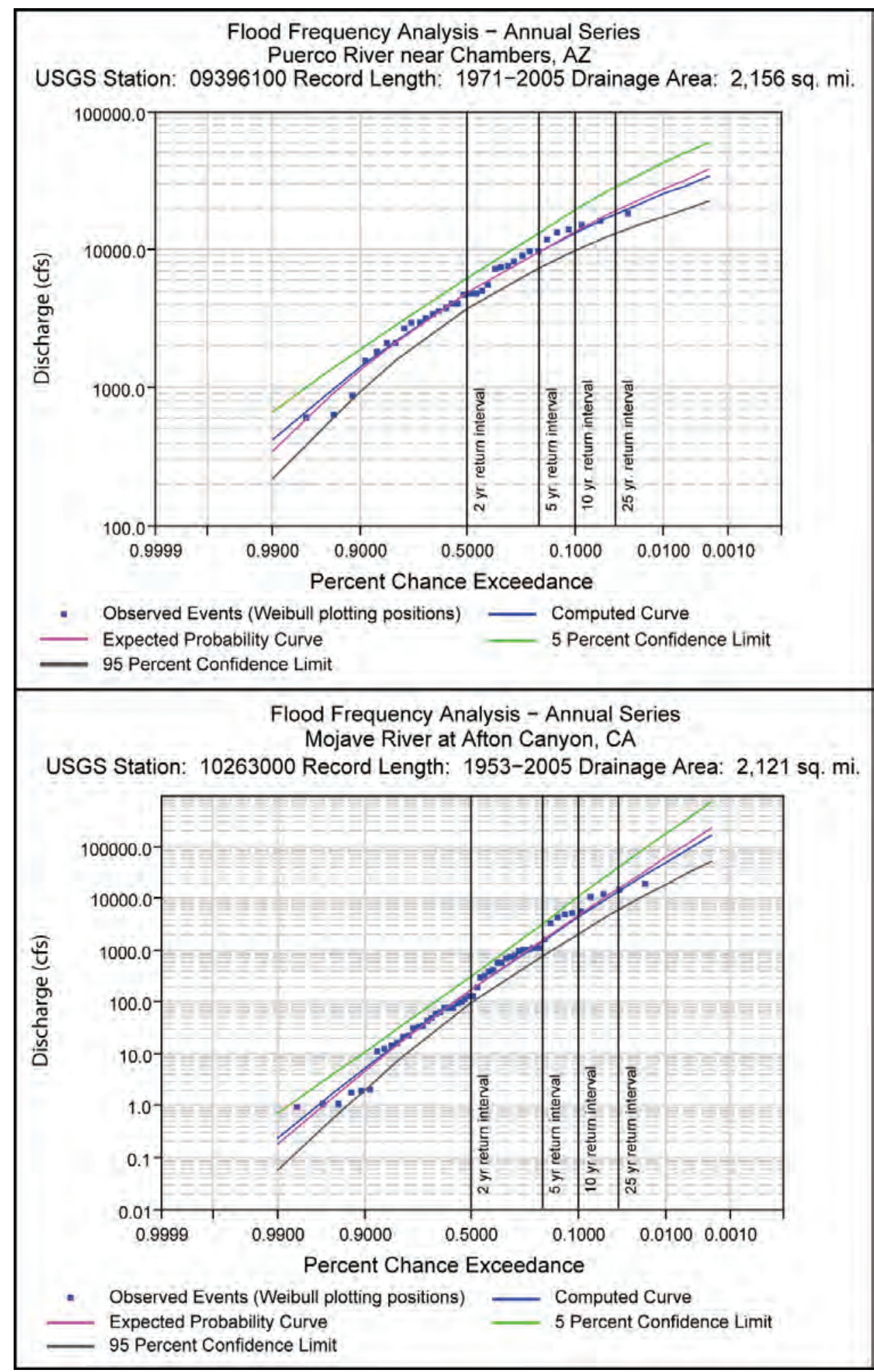

Figure 26. Flood frequency analysis results produced by HEC-SSP in accordance with Bulletin 17B for the Puerco River, near Chambers, AZ (top), and for the Mojave River at Afton Canyon, CA (bottom). Four labeled, vertical lines (black) indicate the positions of 2-, 5-, 10-, and 25-year events. 


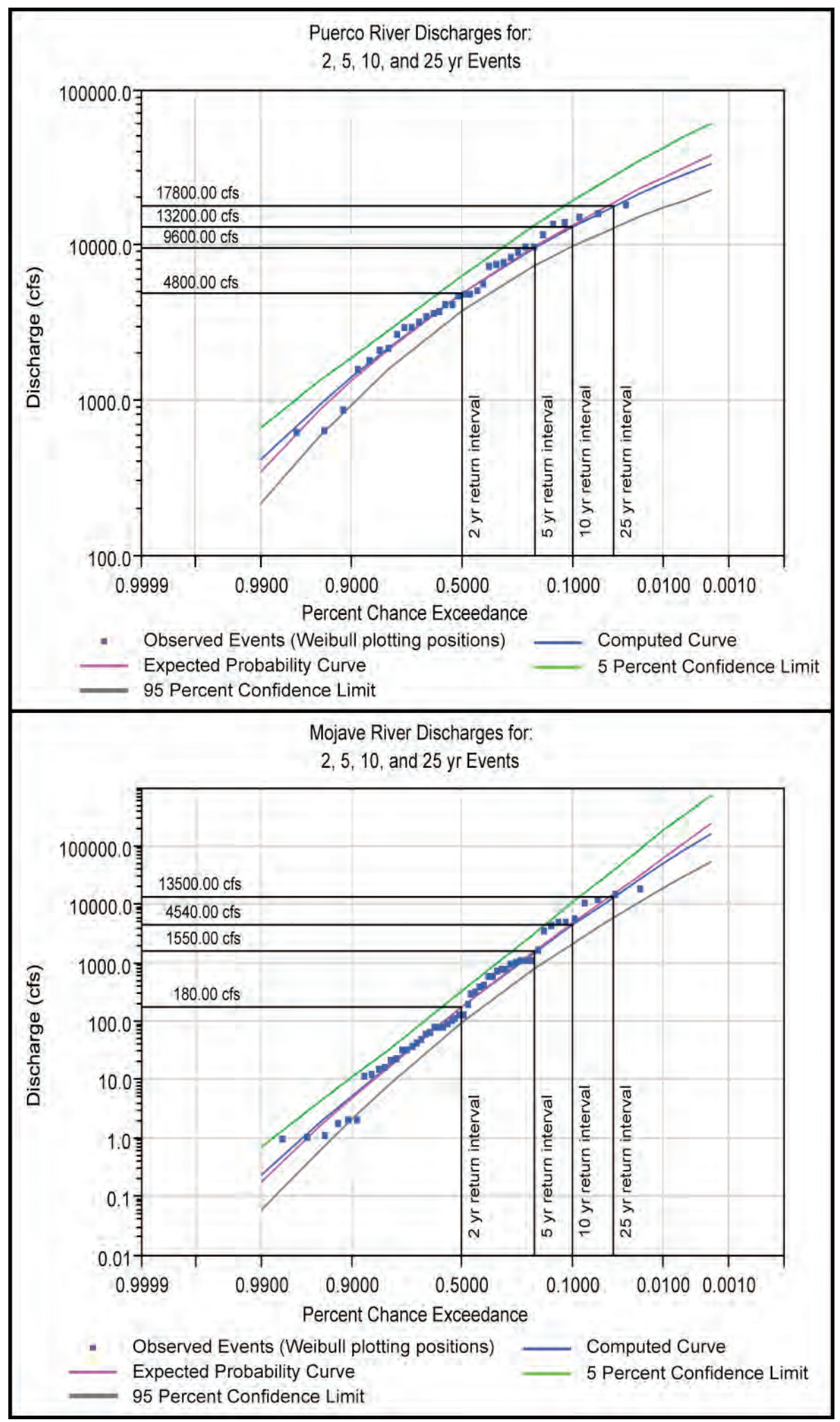

Figure 27. Discharge values (horizontal marker lines) associated with 2-, 5-, 10-, and 25-year events for gage 09396100 on the Puerco River near, Chambers, AZ (top), and for gage 10263000 on the Mojave River at Afton Canyon, CA (bottom). 


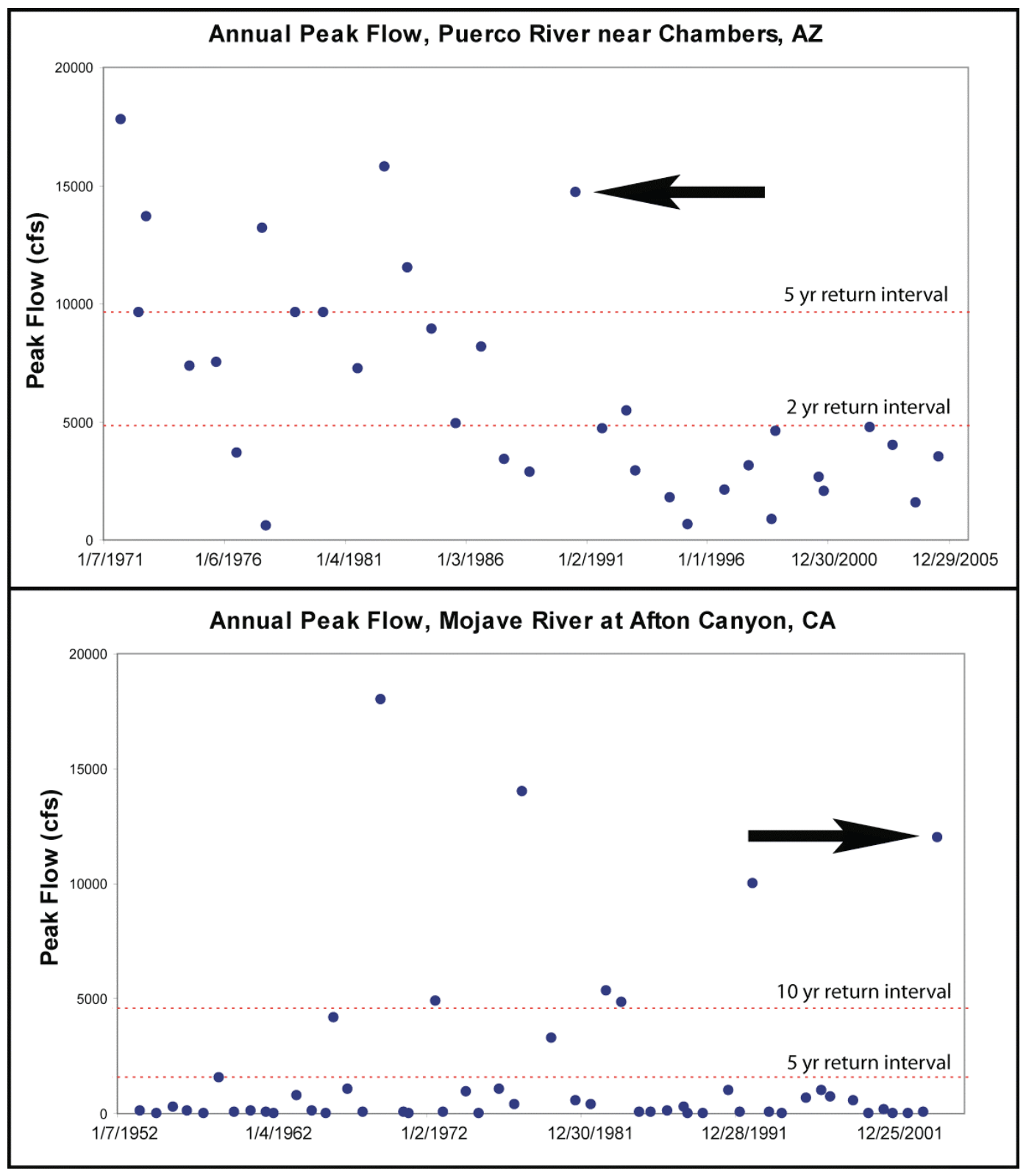

Figure 28. Discharge history for the Puerco River near Chambers, AZ (top), and for the Mojave River at Afton Canyon, CA (bottom). The arrows indicate the most recent effective discharges exceeding a 5-year event for each river. Note the long period of time that has elapsed since the last recorded effective discharge on the Puerco River relative to the recorded event on the Mojave River.

Note that the relationship between stage and discharge is often uncertain. Sources of uncertainty include but are not limited to: potential measurement errors during data collection processes, bed forms, water temperature, debris or other obstructions, unsteady flow effects, variation in hydraulic roughness with season, sediment transport, channel scour or deposition, and changes in channel shape during or as a result of flood 


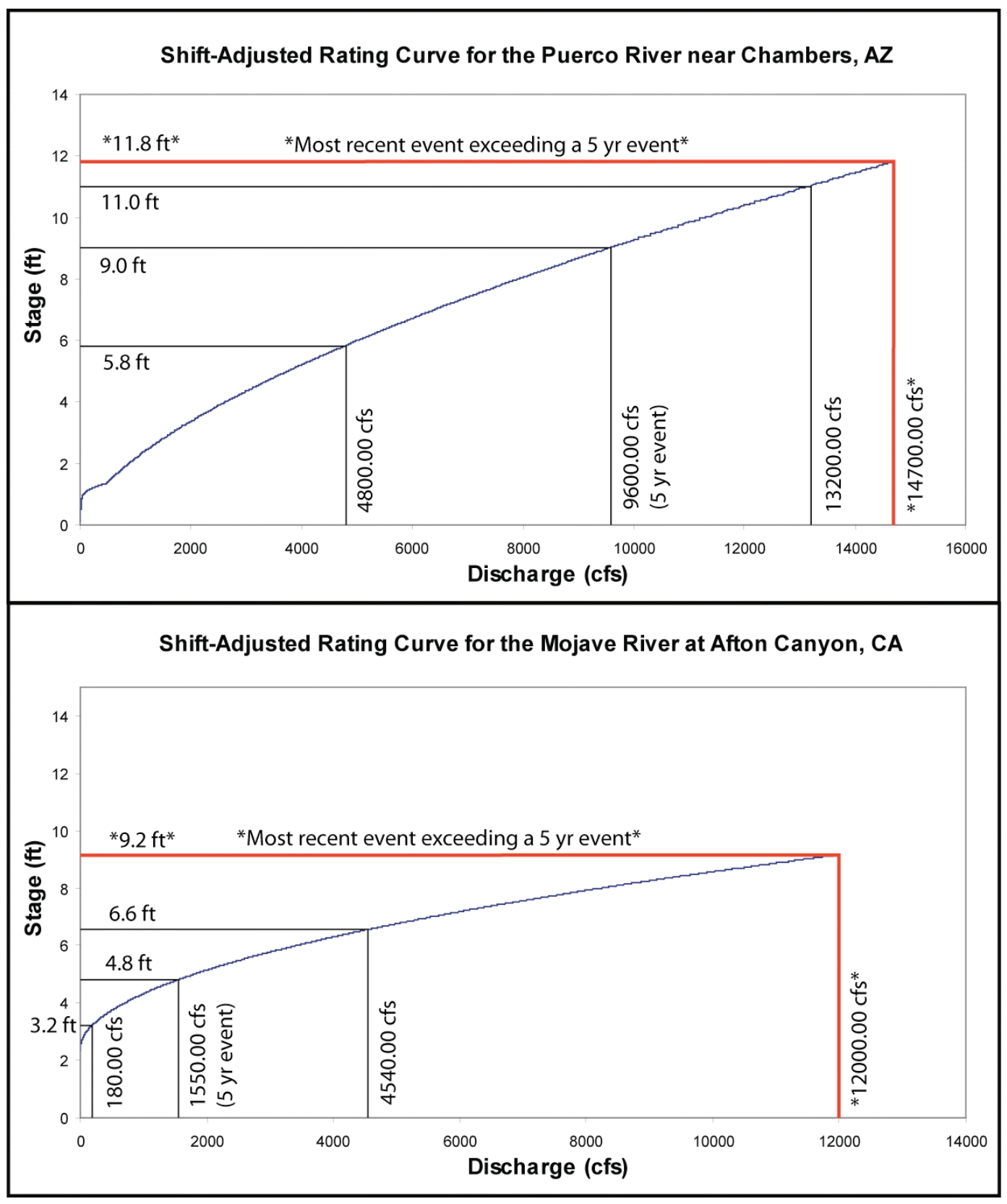

Figure 29. Shift-adjusted rating curve for gage 09396100 on the Puerco River, near Chambers, AZ (top), and for gage 10263000 on the Mojave River at Afton Canyon, CA (bottom). Discharges and associated stage heights are indicated for 2-, 5-, and 10-year events and the most recent event exceeding a 5-year event.

events (U.S. Army Corps of Engineers 1996). Methods to estimate stagedischarge uncertainty include the evaluation of individual contributing factors or all factors combined. Although a complete uncertainty analysis is not necessary or suggested to delineate the limit of OHW at a gaged site, the potential complexity of a delineation in the field can be reduced if, when possible, an estimate of the upper and lower bounds (U.S. Army 
Corps of Engineers 1996) on stage for discharge values of interest (e.g., 2-, 5-, 10-, and 25-year events and the most recent event exceeding a 5-year event) is obtained, during the Preliminary Delineation Procedure.

Once the Preliminary Delineation Procedure is complete, proceed to Section 3.3 (Field Verification of the Preliminary Delineation).

\subsection{Field Verification of the Preliminary Delineation}

Appendix A contains a datasheet that is designed to be used with the steps of the procedure described below. It functions as a checklist to ensure that all appropriate resources and information have been collected and analyzed prior to going into the field, and it is used to document all on-site observations that are relevant to accurately and reliably identifying the limits of non-wetland waters.

1. Walk the channel and one side of the surrounding floodplain (Fig. 30) to get a general impression of the distribution of vegetation, as well as the variety of species that are present within that portion of the study area. Also, note the geomorphic features that will be useful in determining the limit of OHW, such as breaks in slope (see Tables 5 and 7 for other examples). Identify and record surrounding upland land use and hydrologic alteration, as well as structures, both in-stream and on the floodplain (see Table 4 for specific examples).

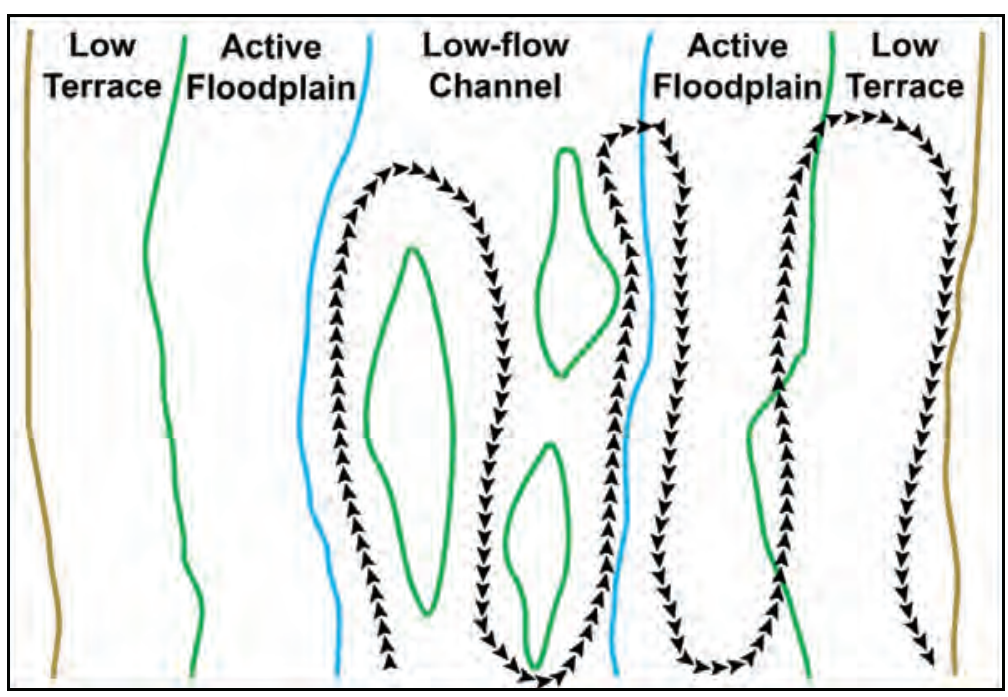

Figure 30 . Step 1 of the field verification procedure. The arrows indicate a potential foot path that would provide an overall impression of the vegetation, geomorphology, upland land use, and hydrologic alteration within the area of interest. 
2. When present, locate the low-flow channel (Fig. 31). In some systems the low-flow channel may be obscured, as in cross-section 2 in Figure 10. If a low-flow channel is not apparent, proceed to step 4. If the low-flow channel is visible, or if there are multiple low-flow channels, observe and record the percent vegetation cover by strata within the feature(s) and approximate the stand age (early successional to mature) based on general size, growth form, and height or thickness of stems or trunks. Finally, note the species composition and, using the scale on the datasheet, determine and record the dominant particle size in the sediment that imparts a general texture to thelow-flow channel.

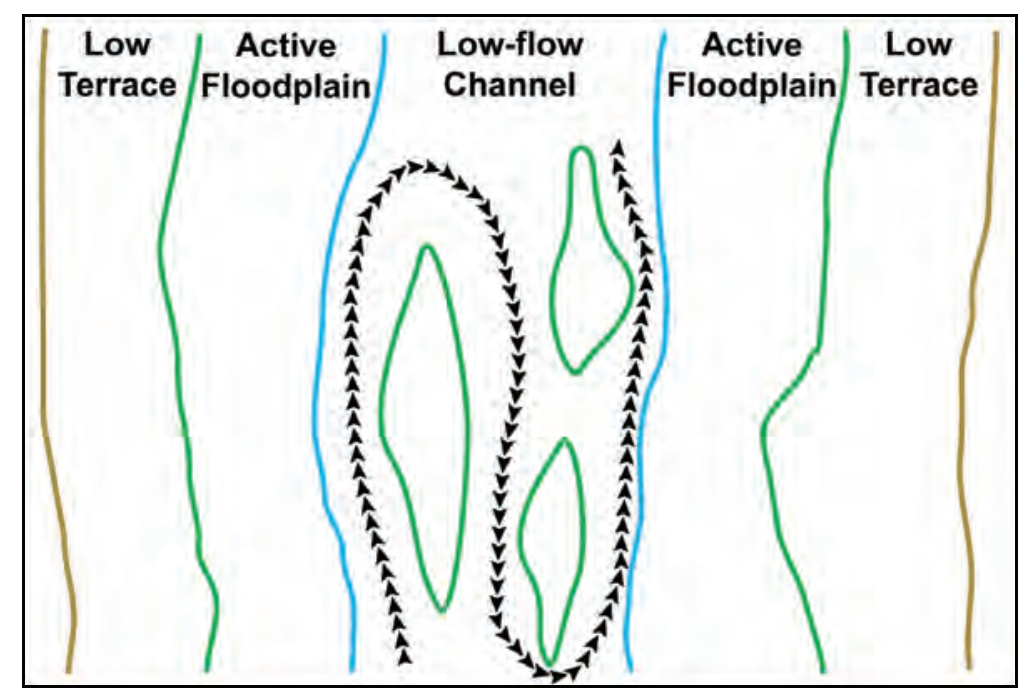

Figure 31 . Step 2 of the field verification procedure. The arrows indicate a potential foot path within the low-flow channel along which percent vegetation cover, stand age, species composition, and dominant sediment texture should be observed and documented.

3. Identify the transition area between the low-flow channel(s) and the active floodplain (the blue linein Fig. 32). Frequently the transition area is defined by a change in vegetation age class or grouth form and/ or species composition. Also, there is often a change in sediment texture and a break in slope coupled with the presence of previously deposited organic debris. While walking in a direction perpendicular to and away from the low-flow channel(s) (along the channel cross-section), track and record changes in percent cover of vegetation and species composition. Also, approximate the stand age (early successional to mature) based on general size, growth form, and height or thickness of stems or trunks. In some systems there may be multiple low-flow channels separated by islands (e.g., green features in the low-flow channel in Fig. 32) that are defined more by 
upland characteristics. In these situations, it may be necessary to walk over or around the islands to determine whether the low-flow channel characteristics are re established on the opposite side. If this is the case, continue walking in a direction perpendicular to and away from the lowflow channel until a consistent change in vegetation and sediment texture associated with a break in slope is identified. Once the transition area is tentatively identified, it may be possible, but not necessary, to support the identification through the use of other indicators listed and pictured in Tables 5, 6, 7, and 8.

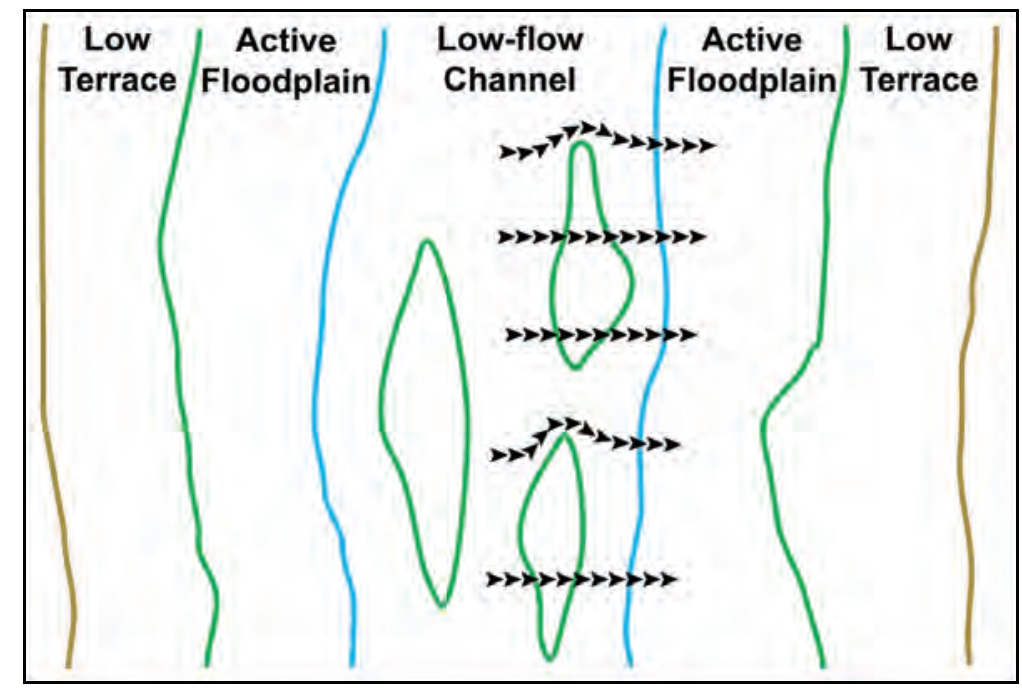

Figure 32. Step 3 of the field verification procedure. The arrows indicate potential foot paths along which changes in percent vegetation cover by strata, stand age, species composition, and dominant sediment textures associated with the low-flow/active floodplain transition should be observed and recorded.

4. Document the general characteristics of the active floodplain. While walking in a direction perpendicular to and away from thelow-flow channel (Fig. 33), record the percent cover of vegetation and species composition. Also, approximate the stand age (early successional to mature) based on general size, growth form, and height or thickness of stems or trunks and, using the scale on the datasheet, determine and record the dominant particle size in the sediment that imparts a general texture to the active floodplain. Finally, search for and document the presence of any other indicators from Tables 5, 6, 7, and 8 that support the identification of the active floodplain. 


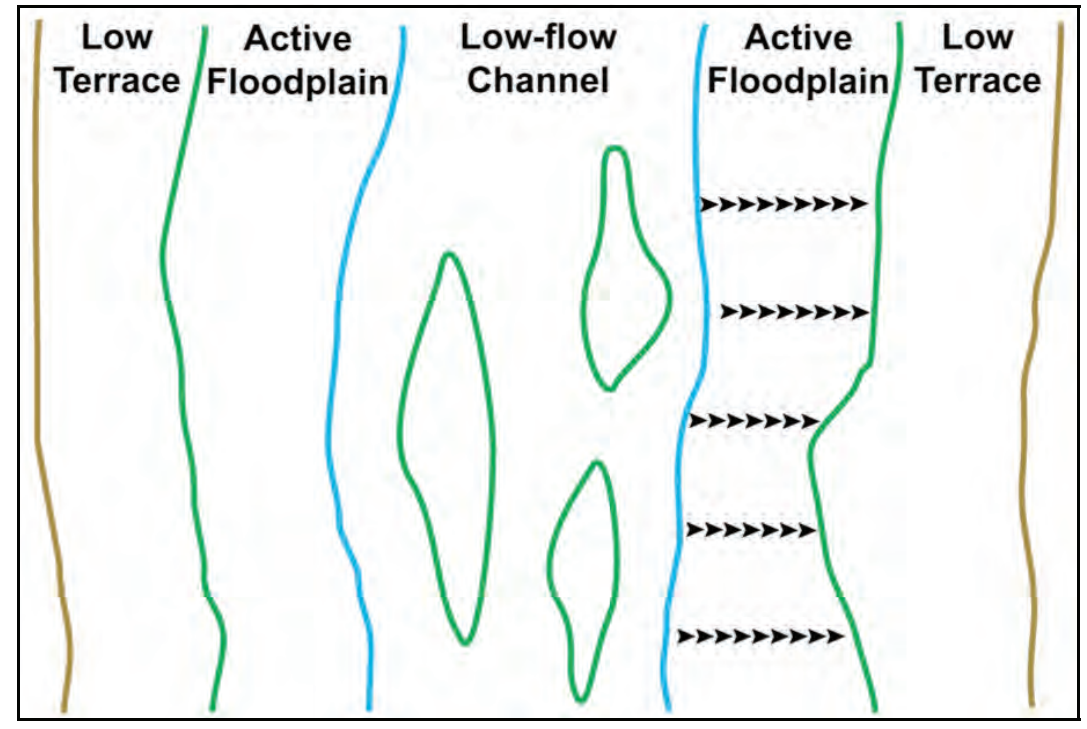

Figure 33. Step 4 of the field verification procedure. The arrows indicate potential foot paths in the active floodplain area along which the general characteristics (percent vegetation cover, stand age, species composition, dominant sediment texture, and any other indicators from Tables 5, 6, 7 , and 8 when present) of the low terrace should be observed and recorded.

5. Identify the transition area between the active floodplain and the low terrace (the green line in Fig. 34). While walkingin a direction perpendicular to and away from the transition area between the low-flow channel and the active floodplain (along the channel cross-section), track and record changes in percent cover of vegetation and species composition. Also, approximate the stand age (early successional to mature) based on general size, growth form, and height or thickness of stems or trunks, and document changes in the dominant sediment texture associated with the active floodplain. When an area has been reached where the vegetative and textural characteristics are markedly different than they were in the active floodplain, it is likely that the transition has been intersected or crossed. Proceed back to where the predominant vegetative and textural characteristics identified in the active floodplain either appear to be mixed with the more recently identified characteristics or where there is a well-defined boundary between the two. At that point conduct a search for other indicators (see Tables 5, 6, 7, and 8 for complete lists and select photographs), such as a break in slope and/or previously deposited organic debris that may support the identification of the outer edge of some active floodplains. Often the edge of the active floodplain will only be identifiable through vegetative and textural characteristics because of the transitory nature of the other indicators. If other indicators are 
consistently observed along with the vegetative and textural characteristics, the transition area between the active floodplain and the low terrace is located along the outer edge (relative to the active floodplain) of all of the indicators. If only the vegetative and textural characteristics are present, the transition area is located along the outer edge of the predominant active floodplain characteristics (i.e., where the predominant vegetative and textural characteristics of the low terrace become prevalent).

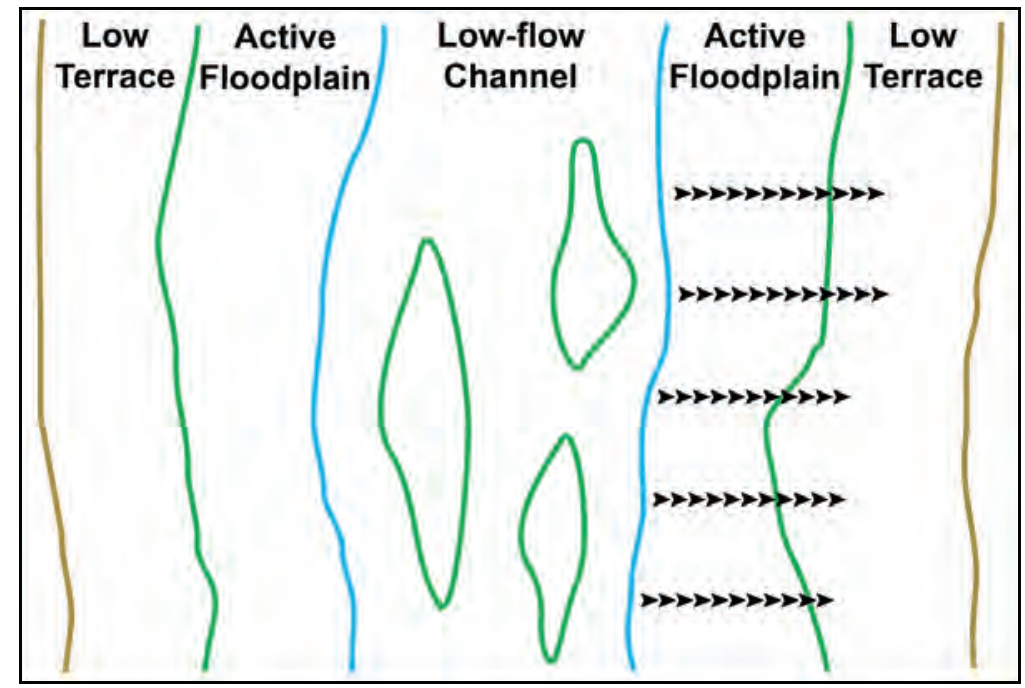

Figure 34. Step 5 of the field verification procedure. The arrows indicate potential foot paths along which changes in percent vegetation cover by strata, stand age, species composition, and dominant sediment textures associated with the active floodplain/low terrace transition should be observed and recorded.

6. Along the outer edge of the predominant active floodplain vegetative and textural characteristics, and, if present, other indicators (see Tables 5, 6, 7, and 8), mark the presumptive transition area between the active floodplain and the low terrace. Attempt to walk along the transition in both the upstream and downstream directions over the entire length of the study area (Fig. 35). While making the bi-directional (longitudinal) traverse, verify that the primary indicators used to identify the transition when it was first intersected are consistently associated with the transition in both directions. Because of the manner in which the transition typically forms, it may be diffuse in areas and it may not be perfectly aligned with the transition area identified between the low-flow channel and the active floodplain. If the transition appears to be lost during the traverse, it may be necessary to backtrack to the last known position and widen the search in 
that area. If the signature cannot be detected after conducting a wider search from the last known position, the transition area identified at the original intersection will need to be revisited. It is possible that the outer edge of the indicators was not identified correctly or that an island of material defined by upland characteristics has been intersected. Under these circumstances, return to Step 2 and repeat the entire procedure. If the indicators are consistently associated with the transition area in both directions, proceed to Step 7.

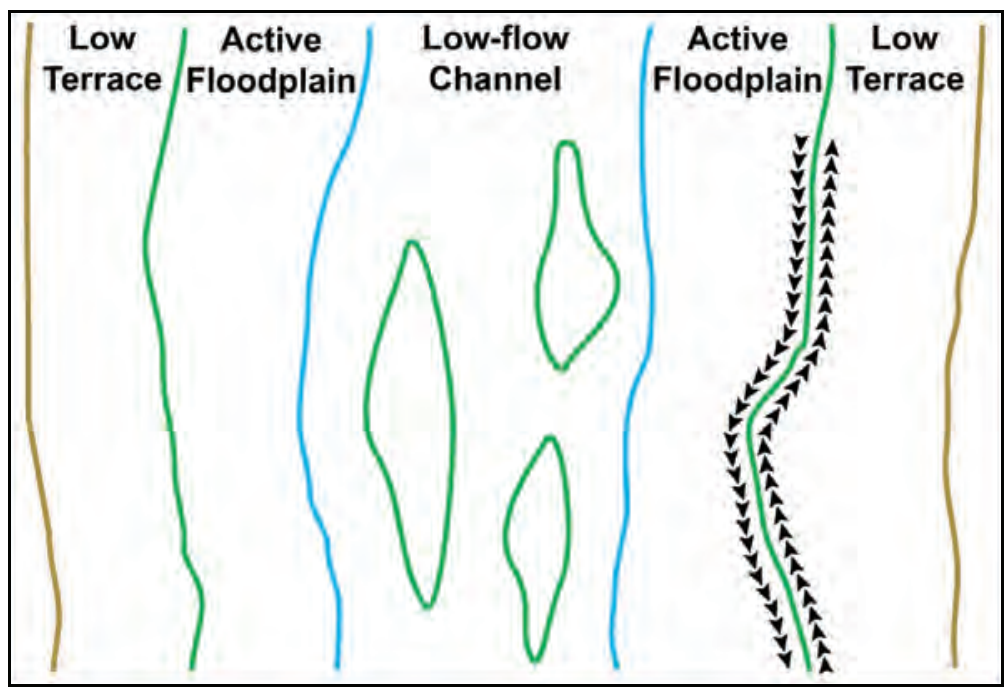

Figure 35. Step 6 of the field verification procedure. The arrows indicate foot paths that should be followed to verify that the transition from the active floodplain to the low terrace identified through observing changes in vegetation, sediment texture, and possibly a break in slope is reliable in both the upstream and downstream directions.

7. After the presumptive transition area between the active floodplain and the low terrace has been traversed in both the upstream and downstream directions, and if the primary indicators are found to be consistently associated with the transition, mark the boundary as the limit of the active floodplain (the green line in Fig. 36). 


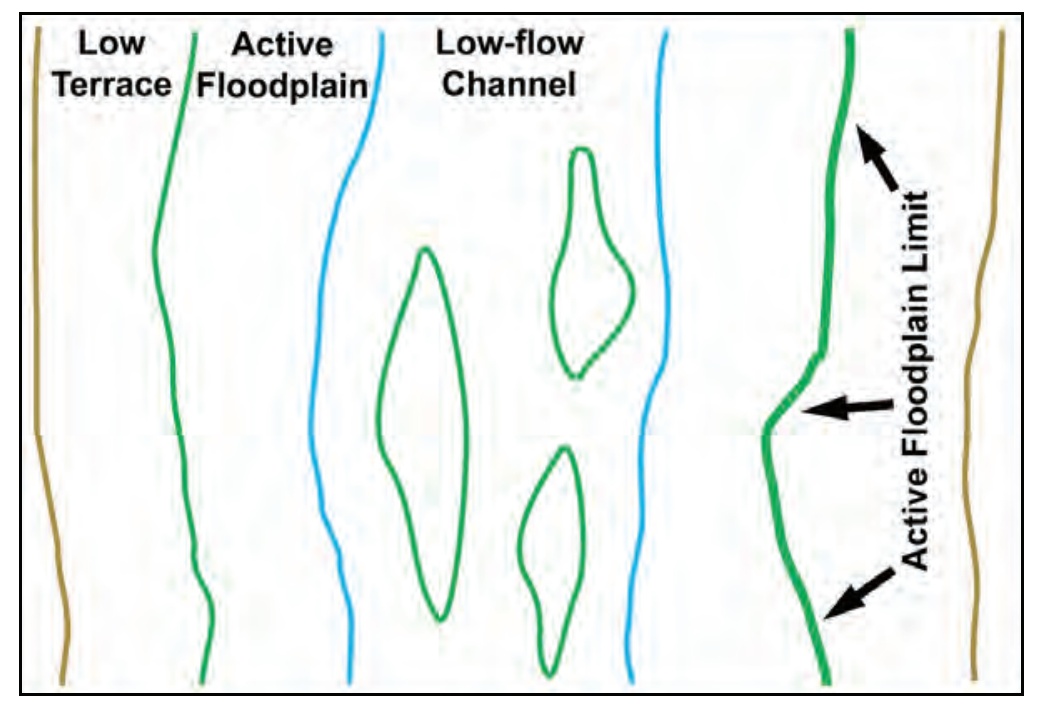

Figure 36. Step 7 of the field verification procedure. The the primary indicators were found to be consistently associated with the transition in both the upstream and downstream directions. Thus the transition marks the limit of the active floodplain in that portion of the study area.

8. Document the general characteristics of the low terrace. While walking in a direction perpendicular to and away from the active floodplain (Fig. 37), record the percent cover of vegetation and species composition. Also, approximate the stand age (early successional to mature) based on general

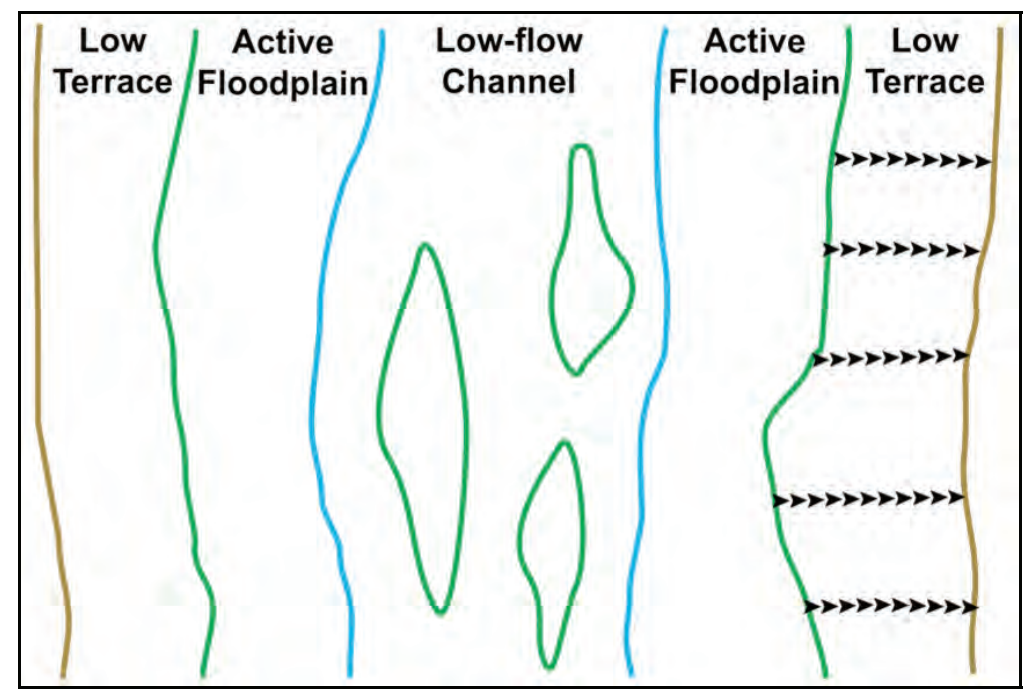

Figure 37. Step 8 of the field verification procedure. The arrows indicate potential foot paths in the low terrace area along which the general characteristics (percent vegetation cover, stand age, species composition, dominant sediment texture, and any other indicators from Tables $5,6,7$, and 8 when present) of the low terrace should be observed and recorded. 
size, grouth form, and height or thickness of stems or trunks and, using the scale on the datasheet, determine and record the dominant particle size in the sediment that imparts a general texture to the low terrace. Finally, search for and document the presence of any other indicators from Tables 5, 6, 7, and 8 that support the identification of the low terrace. To determine the limit of the active floodplain on the other side of the channel, repeat Steps 2-8 walking in the opposite direction perpendicular to and away from a particular feature.

9. If stream gage data are available for the stream reach of interest, proceed through steps a-e. If not, proceed to Step 10.

(a) Locate the staff gage used to determine water height within the channel. The staff gage should be proximal to, or within, the gage housing (Fig. 38).

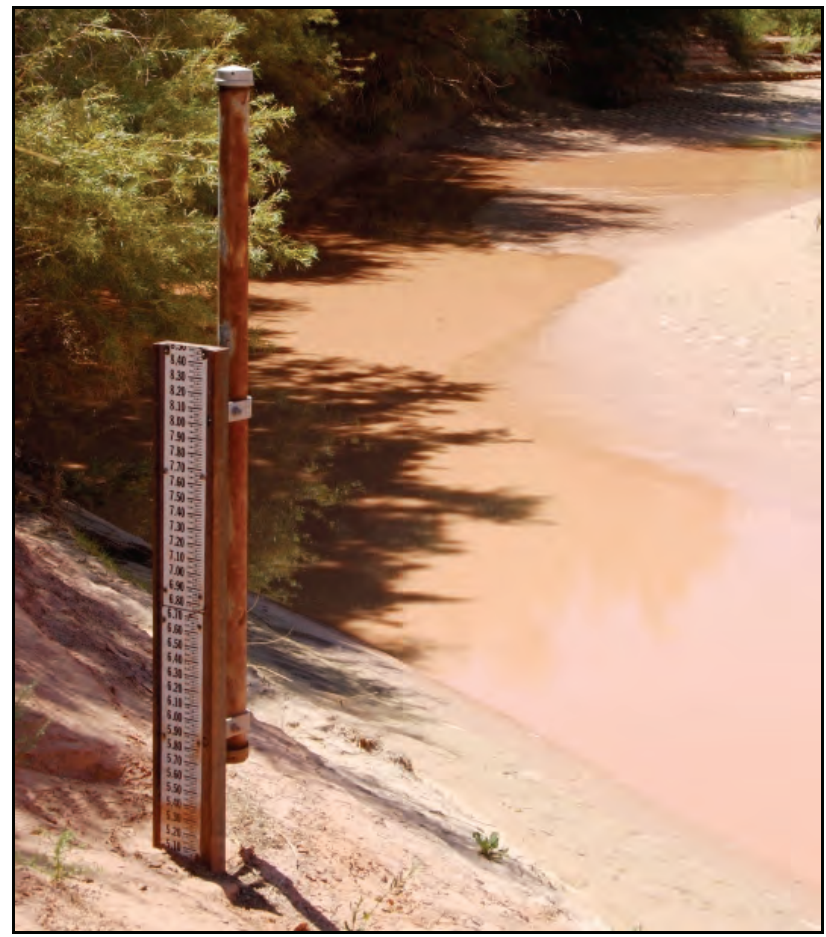

Figure 38. Staff used to determine stage height for Chinle Creek, AZ.

(b) Using a clinometer or level, align the staff gage to the stage height associated with the most recent discharge EXCEEDING A 5YEAR event that was determined in Step 6 of the Preliminary Delineation Procedure. 
(c) Determine the spatial relationship between the limit of the active floodplain marked in Step 7 and the stage height associated with the most recent discharge EXCEEDING A 5-YEAR event that was determined in Step 6 of the Preliminary Delineation Procedure. Looking upstream ( $<50$ yards), project the staff elevation for the event onto the landscape (Fig. 39). It is important to remember that the stage value determined from the best-fit stage- discharge function in Step 6 of the Preliminary Delineation Procedure contains a level of uncertainty. Thus, the spatial relationship between the projected point on the landscape and the limit of the active floodplain, which was identified through the use of physical indicators, may not be exact.

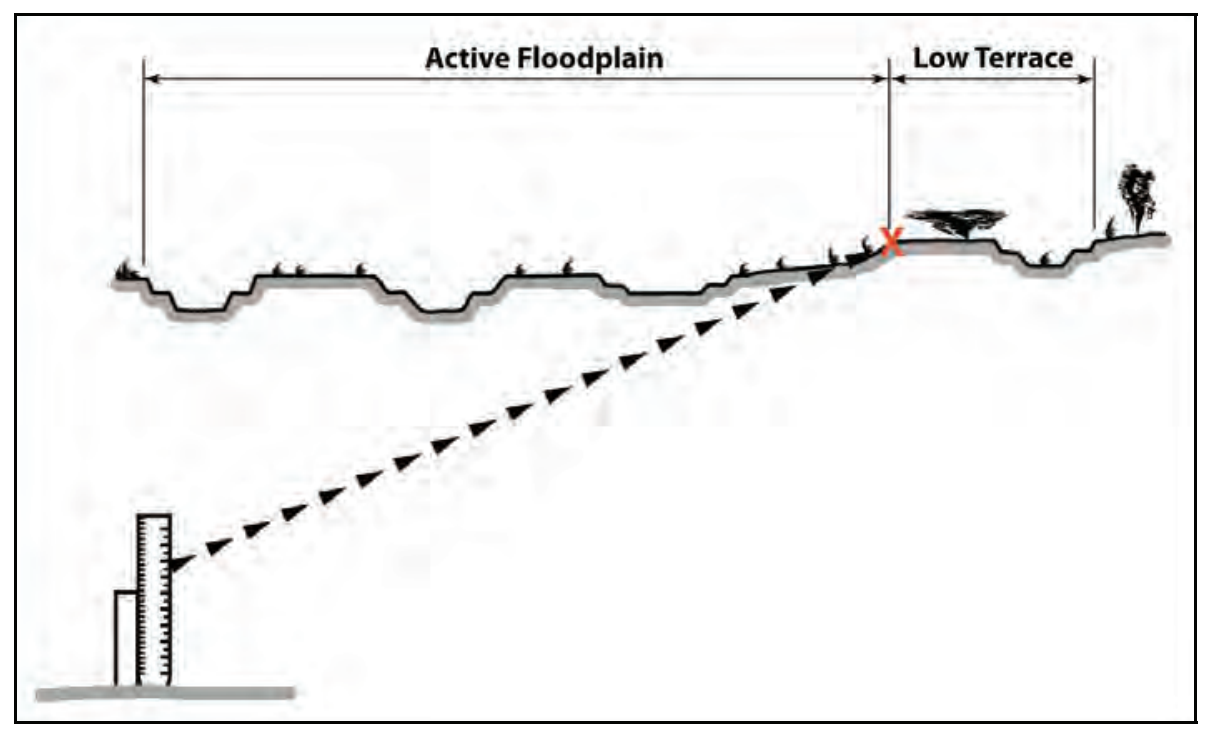

Figure 39. Projection onto the landscape of the stage height associated with the most recent effective discharge that exceeded a 5-year event. The spatial relationship between the location of the point on the landscape and the limit of the active floodplain, indicated by the red $X$, may not be exact due to uncertainty in the stage-discharge relationship.

i. If the projected point on the landscape CORRESPONDS exactly (falls onto or within the transition marked in Step 7) with the identified limit of the active floodplain, proceed to Step 10.

ii. If the projected point on the landscape DOES NOT CORRESPOND exactly with the identified limit of the active floodplain, and if the upper and lower bounds on the stage 
height WERE estimated during the Preliminary Delineation Procedure, determine if the identified limit of the active floodplain falls within the range of stage heights defined by the upper and lower bounds.

- If the limit falls within the range, proceed to Step 10.

- If the limit falls below the range, proceed to Step d.

- If the limit falls above the range, proceed to Step e.

iii. If the projected point on the landscape DOES NOT CORRESPOND exactly with the identified limit of the active floodplain, and if the upper and lower bounds on the stage height are UNKNOWN, determine if the identified limit falls below or above the projected point.

- If the limit falls below the point, proceed to Step d.

- If the limit falls above the point, proceed to Step e.

(d) Determine the spatial relationship between the identified limit of the active floodplain and the stage height associated with THE MOST RECENT 5-YEAR event determined in Step 6 of the Preliminary Delineation Procedure. Project the stage height for the 5-year event onto the landscape.

i. If the projected point CORRESPONDS exactly with the limit of the active floodplain marked in Step 7, repeat Steps 5- 7, starting from that boundary, crossing and examining all transitions until the active floodplain/ low terrace transition is reached. If only the transition between the active floodplain and low terrace is identified after repeating the procedure, the boundary marked in Step 7 is the limit of OHW; proceed to Step 10. If other transitions are crossed between the boundary marked in Step 7 and the low terrace, the outermost transition (inside the active floodplain/low terrace transition) that is consistently characterized in both the upstream and downstream directions by physical indicators is the limit of OHW. Mark the boundary and proceed to Step 10. 
ii. If the projected point DOES NOT CORRESPOND exactly with the identified limit of the active floodplain, and if the upper and lower bounds on the stage height WERE estimated during the Preliminary Delineation Procedure, determine if the limit of the active floodplain falls within the range of stage heights defined by the upper and lower bounds.

- If the limit falls within or below the range, repeat Steps 57 , starting from that boundary, crossing and examining all transitions until the active floodplain/low terrace transition is reached. If only the transition between the active floodplain and low terrace is identified after repeating the procedure, the boundary marked in Step 7 is the limit of OHW; proceed to Step 10. If other transitions are crossed between the boundary marked in Step 7 and the low terrace, the outermost transition (inside the active floodplain/low terrace transition) that is consistently characterized in both the upstream and downstream directions by physical indicators is the limit of OHW. Mark the boundary and proceed to Step 10 .

- If the limit falls above the range, repeat Steps 5- 7 starting from that boundary, crossing and examining all transitions until the active floodplain/ low terrace transition is reached. If only the transition between the active floodplain and low terrace is identified after repeating the procedure, the boundary marked in Step 7 is the limit of OHW; proceed to Step 10. If other transitions are crossed between the boundary marked in Step 7 and the low terrace, the outermost transition (inside the active floodplain/low terrace transition) that is consistently characterized in both the upstream and downstream directions by physical indicators is the limit of OHW. Mark the boundary and proceed to Step 10.

iii. If the projected point on the landscape DOES NOT CORRESPOND exactly with the identified limit of the active floodplain, and if the upper and lower bounds on the stage height are UNKNOWN, repeat Steps 5- 7 starting from that boundary, crossing and examining all transitions until the 
active floodplain/ low terrace transition is reached. If only the transition between the active floodplain and low terrace is identified after repeating the procedure, the boundary marked in Step 7 is the limit of OHW; proceed to Step 10. If other transitions are crossed between the boundary marked in Step 7 and the low terrace, the outermost transition (inside the active floodplain/low terrace transition) that is consistently characterized in both the upstream and downstream directions by physical indicators is the limit of OHW. Mark the boundary and proceed to Step 10.

(e) Either the transition between the low terrace and the surrounding upland (the brown line in Fig. 30- 36) was identified in Steps 5- 7, instead of the active floodplain/low terrace boundary, or the boundary represents a more recent, and probably a larger magnitude, effective discharge than the event used in Step b. Check the recent discharge history to determine if this is the case, and look at the aerial photograph to determine if any channel changes have occurred between the acquisition date and the current date (see Section 3.4, Problematic Boundaries).

10. On the aerial photograph, locate the boundaries of the active floodplain, and delineate the active floodplain within the study area using the changes observed in the field. Clearly draw the boundaries using the aerial photograph as a base, either on paper or digitally using GIS software. When necessary or optionally, the boundaries may also be acquired through survey or the use of a GPS unit.

\subsection{Problematic Boundaries}

Numerous factors can complicate correct identification of the limits of $\mathrm{OHW}$ in such a dynamic environment. Channel changes associated with effective discharges are paramount. Significant alteration of the landscape due to such events, including geomorphic and vegetative changes, can place the channel system in a state of disequilibrium. Establishment of a new equilibrium can result in a significantly different channel geometry and vegetative distribution. The following scenarios are examples where the delineation technique outlined in Sections 3.2 and 3.3 may not work as intended, and alternative approaches are necessary. 
1. Because aerial photograph interpretation is used in the delineation procedure, channel changes can be a source of confusion. The ground conditions may have changed between the acquisition date of the photograph and the date of the attempted delineation. When this happens, care must be taken to identify reference points within the study area that have not changed, as well as the parts of the channel that have. In these situations, a GPS unit may substantially reduce the complexity of acquiring the boundary of OHW. Once the boundary has been identified through the use of physical indicators in the field, and the corresponding GPS data have been obtained, they can be aocurately overlain on a geo-rectified aerial photograph regardless of discrepancies between the scene in the photograph and the on-site conditions. When GPS is not available, the observations of current site conditions must be combined with aerial photograph interpretations to best identify the boundary of OHW in the study area.

2. In gaged systems, stage heights may not be associated with features in the field due to the impact of recent effective discharges. If there has been one or more recent effective discharge within the system of interest, the channel geometry may have changed due to bed scour and deposition. In situations where the stage heights determined from the best-fit stagedischarge function do not appear to be associated with channel features, the spatial relationships should be documented, and the limit of OHW is delineated through the use of physical indicators only.

\subsection{Examples of Delineations by Channel Form}

The observed patterns used to delineate the OHWM vary between different types of channel forms. An example delineation of geomorphic features and extent of OHW (the active floodplain/low terrace boundary) is provided for each of the channel forms discussed in Section 1.5.

\subsubsection{Alluvial Fans}

Alluvial fans present unique difficulties in identifying hydrogeomorphic floodplain units. As the main stem travels downstream on the alluvial fan, it begins to become distributary, branching out over a large area.

Determining which branches are currently active can be difficult, but with careful observation, proper identification of the low-flow channel and active and terrace floodplain is achievable. Delineating the OHW on a fan 
involves determining the active channels and then determining the lateral extent of the OHW.

\subsubsection{Compound Channels}

Compound channels are characterized by a mosaic of terraces within a wide, active floodplain and frequently shifting low-flow channel(s). Figure 40 shows an example of the spatial arrangement of channel features associated with compound channels.
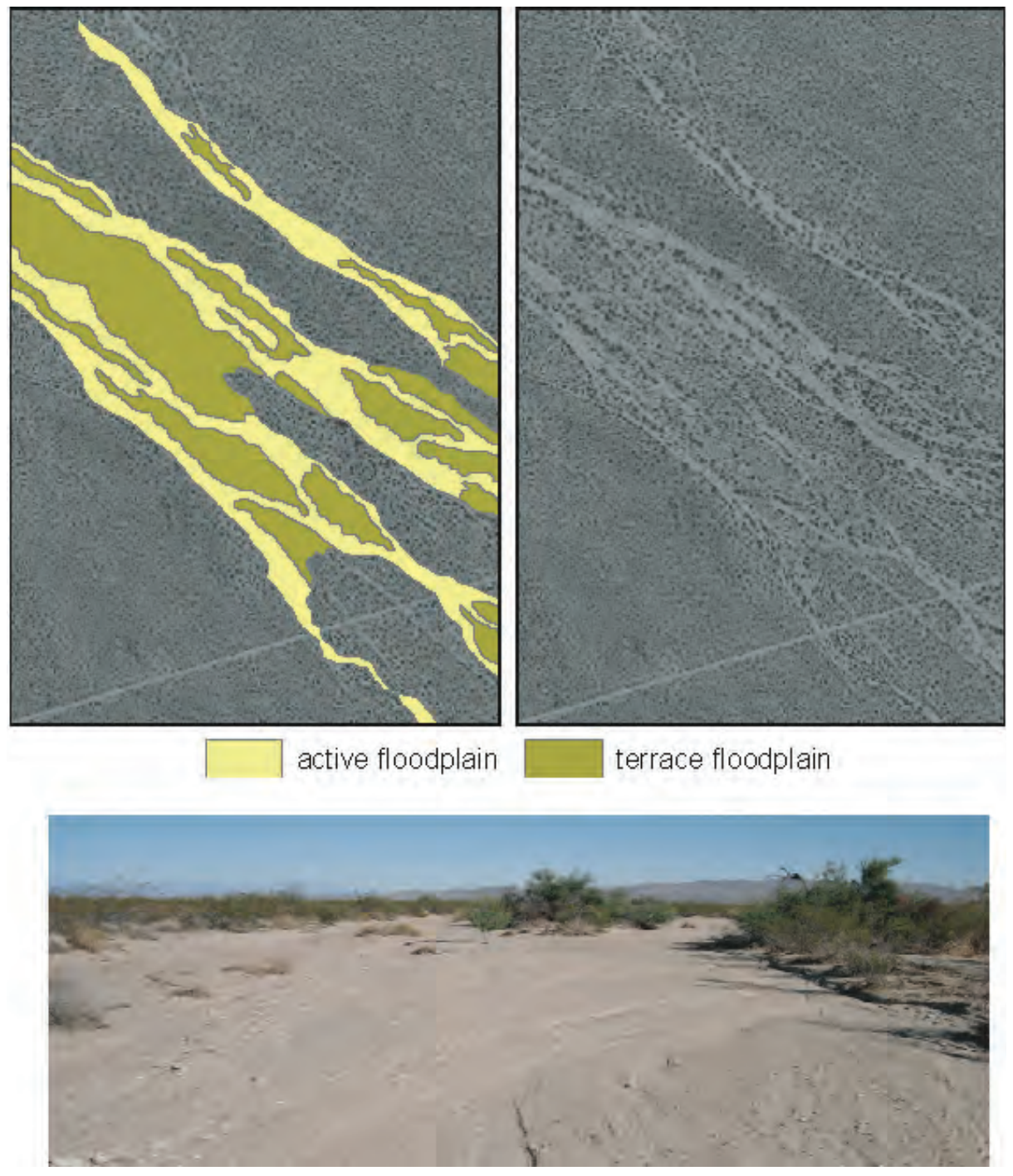

Figure 40. Example geomorphic mapping of a compound channel showing a mosaic of terraces within the active floodplain, Caruthers Creek, CA. 


\subsubsection{Discontinuous Ephemeral Streams}

Three channel forms are present within the discontinuous ephemeral stream type: erosional, depositional, and sheetflood zone. Erosional reaches, or arroyos, are commonly entrenched to the point that there is little to no terrace, except for colluvial deposits being reworked only during extremely rare events (Fig. 41). Arroyo streams are therefore more easily delineated, as most of the incised area is within the low-flow and active floodplain. Depositional and sheetflood zones are more difficult to delineate, as the active part of the channel is more dynamic. Sheetflood zones in particular are a challenge due to the unconfined nature of floodflow, resulting in a wide mosaic of aquatic and upland features.
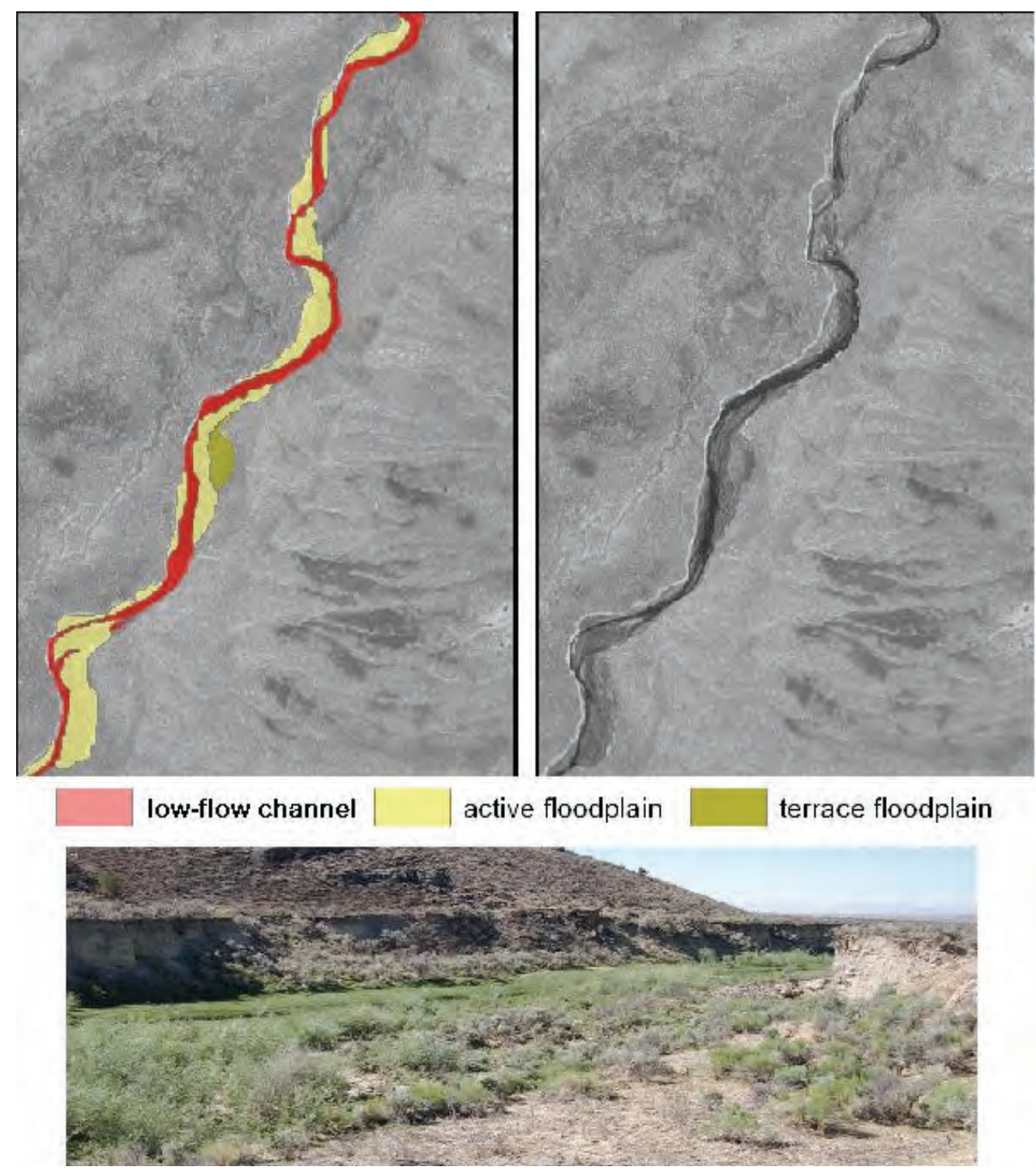

Figure 41. Example geomorphic mapping of a discontinuous ephemeral stream in an erosional reach (arroyo), Susie Creek, NV. 


\subsubsection{Single-Thread Channels with Adjacent Floodplains}

Typified by meandering and straight channel forms, single-thread channels refer to stream systems with typically one low-flow channel. An active floodplain is normally present on the inside of meandering bends and along one or both banks along straight reaches. Figure 42 shows an example of the distribution of geomorphic features within a straight reach of single-thread channel with an adjacent floodplain.
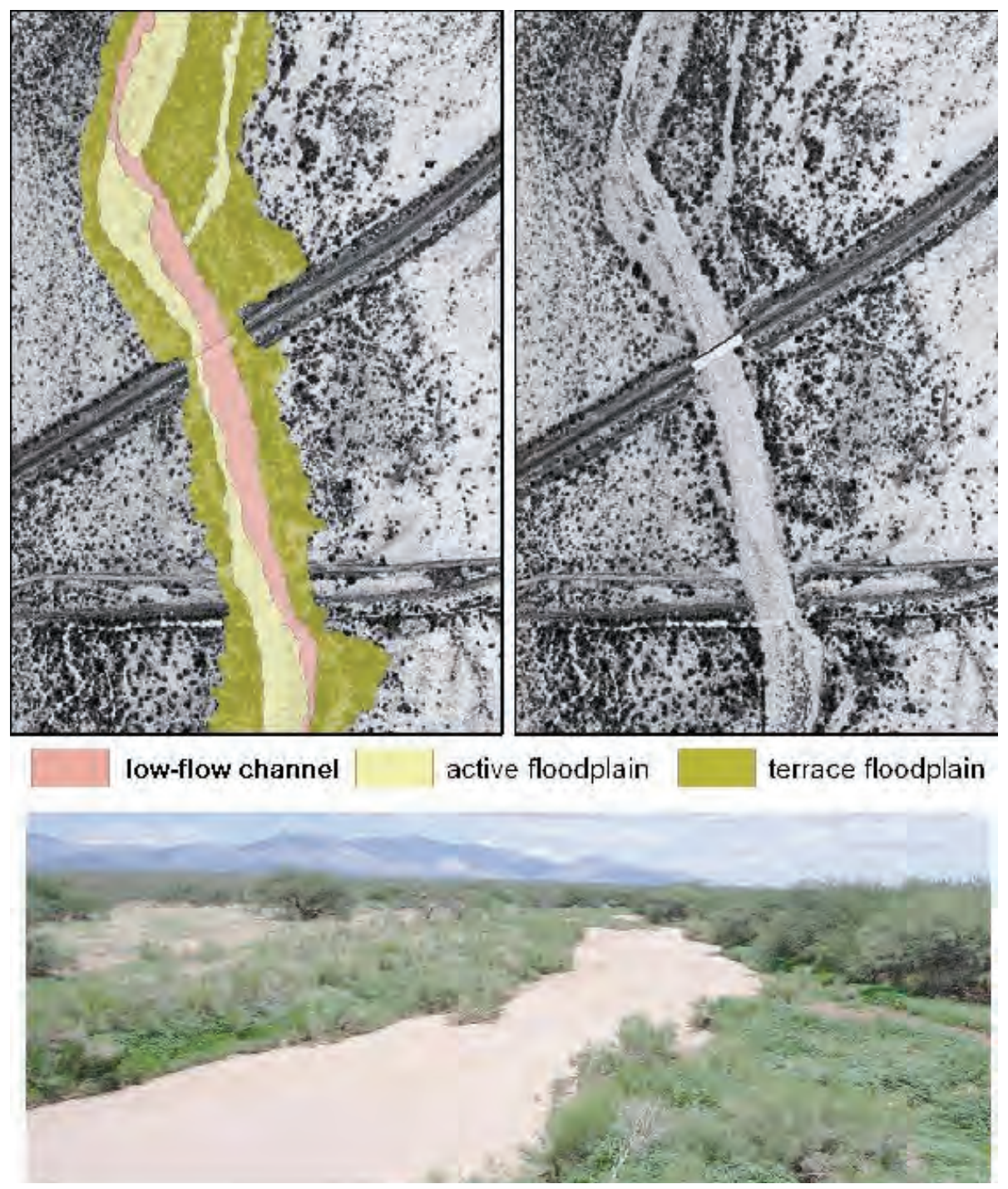

Figure 42. Example geomorphic mapping in a straight reach of a single-thread channel with an adjacent floodplain, Alter Wash, AZ.

\subsubsection{Anastomosing Rivers}

These rivers have much more stable channel geometries than other types due to the fine matrix of bank material and the abundance of stabilizing 
vegetation. Although uncommon in the Arid West region, anastomosing rivers do occur where conditions are present for their formation. Levees form naturally on these channels, making a very narrow active floodplain. Overbank flooding occurs during levee breaches, but the location of these breaches is unpredictable. Due to the scarcity of these channel types, an example is not provided. 


\section{References}

Andrews, E.D., R.C. Antweiler, P.J . Neiman, and F.M. Ralph. 2004. Influence of ENSO on flood frequency along the California coast. J ournal of Climate 17(2): 337-348.

Antsey, R.L. 1965. Physical characteristics of alluvial fans. Technical Report ES-20. Natick, MA: U.S. Army Laboratories.

Auble, G.T., J.M. Friedman, and M.L. Scott. 1994. Relating riparian vegetation to present and future streamflows. Ecological Applications 4: 544-554.

Bendix, J . 1999. Stream power influence on southern Californian riparian vegetation. J ournal of Vegetation Science 10: 243- 252.

Bull, W.B. 1997. Discontinuous ephemeral streams. Geomorphology 19: 227-276.

CH2M Hill and French, R.H. 1992. Alluvial fan data collection and monitoring study [Flood Control District of Maricopa County, Phoenix, AZ]. CH2M Hill, Tempe, AZ, and R.H. French, Las Vegas, NV.

Dunne, T., and L.B. Leopold. 1978. Water in environmental planning. San Francisco: W.H. Freeman.

Ely, L.L. 1997. Response of extreme floods in the southwestern United States to climatic variations in the Holocene. Geomorphology 19: 175- 201.

Field, J.J ., and R.W. Lichvar. 2007. Review and synopsis of natural and human controls on fluvial channel processes in the arid west. ERDC/ CRREL TR-07-16. Hanover, NH: U.S. Army Engineer Research and Development Center, Cold Regions Research and Engineering Laboratory.

French, R.H., J.E. Fuller, and S. Waters. 1993. Alluvial fan: Proposed new processoriented definitions for arid southwest. J ournal of Water Resources Planning and Management 119: 4785.

Graf, W.L. 1979. Rapids in canyon rivers. J ournal of Geology 87: 533- 551.

Graf, W.L. (1988a) Definition of floodplains along arid-region rivers. In Flood geomorphology. V.R. Baker, R.C. Kochel, P.C. Patton, ed. New York: SpringerVerlag.

Interagency Advisory Committee on Water Data. 1982. Guidelines for determining flood flow frequency. Bulletin 17B. Reston, VA: Hydrology Subcommittee, Office of Water Data Coordination, U.S. Geological Survey.

Leopold, L., M.G. Wolman, and J.P. Miller. 1964. Fluvial processes in geomorphology. San Francisco and London: W.H. Freeman and Co. 
Lichvar, R.W., and J.S. Wakeley, ed. 2004. Review of Ordinary High Water Mark indicators for delineating arid streams in the southwestern United States. ERDC/ CRREL TR-04-1. Hanover, NH: U.S. Army Engineer Research and Development Center, Cold Regions Research and Engineering Laboratory. (http:// www.crrel.usace.army.mil/techpub/CRREL_Reports/reports/TR0421.pdf).

Lichvar, R.W., D. Finnegan, M. Ericsson, and W. Ochs. 2006. Distribution of Ordinary High Water Mark (OHWM) indicators and their reliability in identifying the limits of "Waters of the United States" in arid southwestern channels. ERDC/ CRREL TR-06-5. Hanover, NH: U.S. Army Engineer Research and Development Center, Cold Regions Research and Engineering Laboratory. (http:/ / www.crrel.usace.army.mil/techpub/CRREL_Reports/reports/TR065.pdf).

Millar, R.G. 2000. Influence of bank vegetation on alluvial channel patterns. Water Resources J ournal 205: 59- 75.

Reid, I., and L.E. Frostick. 1997. Channel form, flow and sediments in deserts. In Arid zone geomorphology: Process, form and change in drylands. D.S.G. Thomas, ed. Second edition. P. 205-229. Chicester, England: J ohn Wiley \& Sons.

Reid, I., and J.B. Laronne. 1995. Bedload sediment transport in an ephemeral stream and a comparison with seasonal and perennial counterparts. Water Resources Research 31: 773- 781.

Riggs, H.C. 1985. Streamflow characteristics. Amsterdam, The Netherlands, and New York, NY: Elsevier.

Rosgen, D. 1996. Applied river morphology. Pagosa Springs, CO: Wildland Hydrology.

Schindler, R.J ., and A. Robert. 2004. Suspended sediment concentration and the rippledune transition. Hydrological Processes 18: 3215-3227.

Schumann, R.R. 1989. Morphology of Red Creek, Wyoming, An arid-region anastomosing channel system. Earth Surface Processes and Landforms 14: 277- 288.

Stromberg, J .C. 1993. Instream flow models for mixed deciduous riparian vegetation within a semiarid region. Regulated Rivers 8: 225- 235.

Stromberg, J .C., R. Tiller, and B.D. Richter. 1996. Effects of groundwater decline on riparian vegetation of semiarid regions: The San Pedro, Arizona. Ecological Applications 6: 113- 131.

Stromberg, J .C. 1998. Dynamics of Fremont cottonwood (Populus fremontii) and saltcedar (Tamarix chinensis) populations along the San Pedro River, Arizona. J ournal of Arid Environments 40: 133- 155.

Tooth, S. 2000. Process, form and change in dryland rivers: A review of recent research. Earth-Science Reviews 51: 67- 107. 
U.S. Army Corps of Engineers. 1996. Engineering and Design, Risk-based analysis for flood damage reduction studies. EM 1110-2-1619. Washington, DC: U.S. Army Corps of Engineers. (http:// www.usace.army.mil/publications/ eng-manuals/ em1110-2-1619/).

U.S. Army Corps of Engineers. 2006. Interim regional supplement to the Corps of Engineers Wetland Delineation Manual: Arid West Region. J.S. Wakeley, R.W. Lichvar, and C.V. Noble, ed. ERDC/ EL TR-06-16. Vicksburg, MS: U.S. Army Engineer Research and Development Center, Environmental Laboratory.

U.S. Army Corps of Engineers, South Pacific Division. 2001. Final summary report: Guidelines for jurisdictional determinations for water of the United States in the arid Southwest. San Francisco, CA: U.S. Army Corps of Engineers, South Pacific Division. (http:// www.spl.usace.army.mil/ regulatory/lad.htm).

USDA Natural Resources Conservation Service. 2006. Land resource regions and major land resource areas of the United States, the Caribbean, and the Pacific Basin. Agriculture Handbook 296. Washington DC: U.S. Department of Agriculture. (http:// soils.usda.gov/ survey/geography/ mlra/index.html).

Webb, R.H., P.T. Pringle, S.L. Reneau, and G.R. Rink (1988) Monument Creek debris flow, 1984, Implications for formation of rapids on the Colorado River in Grand Canyon National Park. Geology 16: 50-54.

Williams, G.P. 1978. Bank-full discharges of rivers. Water Resources Research 14(6): 1141- 1153.

Wolman, M.G., and J.P. Miller. 1960. Magnitude and frequency of forces in geomorphic processes. J ournal of Geology 68: 54- 74. 


\section{Appendix A: Glossary}

Aggradation. An increase in the channel bed elevation through deposition of sediment.

Arroyo. Entrenched ephemeral streams with vertical walls that form in desert environments.

Assemblage. A collection of individual plant species.

Avulsion. The rapid diversion of flow from one channel into another due to blockage of the channel by sediment or debris.

Calcrete. A conglomerate consisting of surficial sand and gravel cemented into a hard mass by calcium carbonate.

Caliche rubble. Fragments of a sedimentary rock formed by evaporation and precipitation of calcite ( $\mathrm{CaCO} 3)$ in soil, sediments, or preexisting rock.

Clonal species. A group of genetically identical individuals growing in a given location, all originating vegetatively (not sexually) from a single ancestor.

Debris flow. A moving mass of rock fragments, soil, and mud where more than $50 \%$ of the particles are larger than sand-sized.

Desert pavement. Tightly interlocking gravel at the surface formed after years of surface exposure in the absence of active streamflow over the surface.

Desert varnish. A thin, dark, shiny film, composed of iron oxide with traces of manganese oxide and silica, formed on the surface of pebbles, boulders, and rock outcrops in desert regions after long exposure.

Divide. High ground that forms the boundary of a watershed. 
Drift. Organic debris oriented to flow direction(s) (larger than small twigs).

Effective discharge. Discharge that is capable of carrying a large proportion of sediment over time.

Facultative wetland (FACW). Wetland indicator category; species usually occurs in wetlands (estimated probability 67-99\%) but occasionally found in non-wetlands.

Flashy discharge pattern. Periods of no flow or low-magnitude, highfrequency events separated by short-duration, high-magnitude, lowfrequency events.

Floodplain. That portion of a drainage basin (see watershed), adjacent to the channel, that is covered by sediments deposited during overbank flood flow.

Headcut. An abrupt vertical drop in the bed of a stream channel that is an active erosion feature.

Herbaceous. Pertaining to plants with little or no woody tissue.

Hydraulic parameters. Slope, roughness, channel geometry, discharge, velocity, turbulence, fluid properties, sediment size, etc.

Hydraulic roughness. Channel boundary characteristic contributing to energy losses, commonly described by Manning's roughness coefficient (n).

Hydric soil. A soil that formed under conditions of saturation, flooding, or ponding long enough during the growing season to develop anaerobic conditions in the upper part.

Hydrologic regime. Characteristic pattern of precipitation, runoff, infiltration, and evaporation affecting a water body.

Hydromesic. Physiographic class; soil retains water for long periods of time, will drain. 
Hyperconcentrated flow. Suspension flow with large suspended sediment concentrations (i.e., greater than 1-3\%).

Litter. Organic debris oriented to flow direction(s) (small twigs and leaves).

Reach. A segment of a stream channel.

Ruderals. Disturbance-adapted herbaceous plant.

Obligate wetland (OBL). Wetland indicator category; species occurs almost always (estimated probability 99\%) under natural conditions in wetlands.

Pioneer species. A species that colonizes a previously uncolonized area.

Rating curve. A curve that illustrates the relationship between depth (stage) and the amount of flow (discharge) in a channel.

Scour. Soil and debris movement.

Sheetflood. Sheet of unconfined floodwater moving down a slope; a relatively low-frequency, high-magnitude event.

Sheetflow. Overland flow occurring in a continuous sheet; a relatively high-frequency, low-magnitude event.

Shift-adjusted rating curve. A curve that reflects changes (shifts) in the rating for a gage. Ratings may change due to erosion or deposition within the streambed or growth of riparian vegetation.

Stream power. The rate of doing work, or a measure of the energy available for moving rock, sediment, or woody or other debris in a stream channel, as determined by discharge, water surface slope, and the specific weight of water.

Succession. Changes in the composition or structure of an ecological community. 
Transmission loss. Loss of discharge due to infiltration of flow into the channel bed and banks.

Wash. Broad gravelly dry bed of an intermittent stream.

Watershed (drainage basin). An area of land that drains to a single outlet and is separated from other watersheds by a divide.

Xeric. Relating or adapted to an extremely dry habitat. 


\section{Appendix B: Datasheet}




\begin{tabular}{|c|c|c|}
\hline $\begin{array}{l}\text { Project: } \\
\text { Project Number: } \\
\text { Stream: } \\
\text { Investigator(s): } \\
\end{array}$ & $\begin{array}{l}\text { Date: } \\
\text { Town: } \\
\text { Photo begin file\# }\end{array}$ & $\begin{array}{l}\text { Time: } \\
\text { State: } \\
\text { Photo end file\# }\end{array}$ \\
\hline $\begin{array}{l}\mathrm{Y} \square / \mathrm{N} \square \text { Do normal circumstances exist on the site? } \\
\mathrm{Y} \square / \mathrm{N} \square \text { Is the site significantly disturbed? }\end{array}$ & $\begin{array}{l}\text { Location Details: } \\
\text { Projection: } \\
\text { Coordinates: }\end{array}$ & Datum: \\
\hline
\end{tabular}

\section{Notes:}

\section{Brief site description:}

\section{Checklist of resources (if available):}

Aerial photography

Dates:

Topographic maps

Scale:

$\square$ Geologic maps

$\checkmark$ Vegetation maps

$\square$ Soils maps

Rainfall/precipitation maps

Existing delineation(s) for site

Global positioning system (GPS)

Other studies
Stream gage data

Gage number:

Period of record:

$\square$ Clinometer / level

$\square$ History of recent effective discharges

Results of flood frequency analysis

$\square$ Most recent shift-adjusted rating

$\square$ Gage heights for 2-, 5-, 10-, and 25-year events and the most recent event exceeding a 5-year event

The dominant Wentworth size class that imparts a characteristic texture to each zone of a channel cross-section is recorded in the average sediment texture field under the characteristics section for the zone of interest.

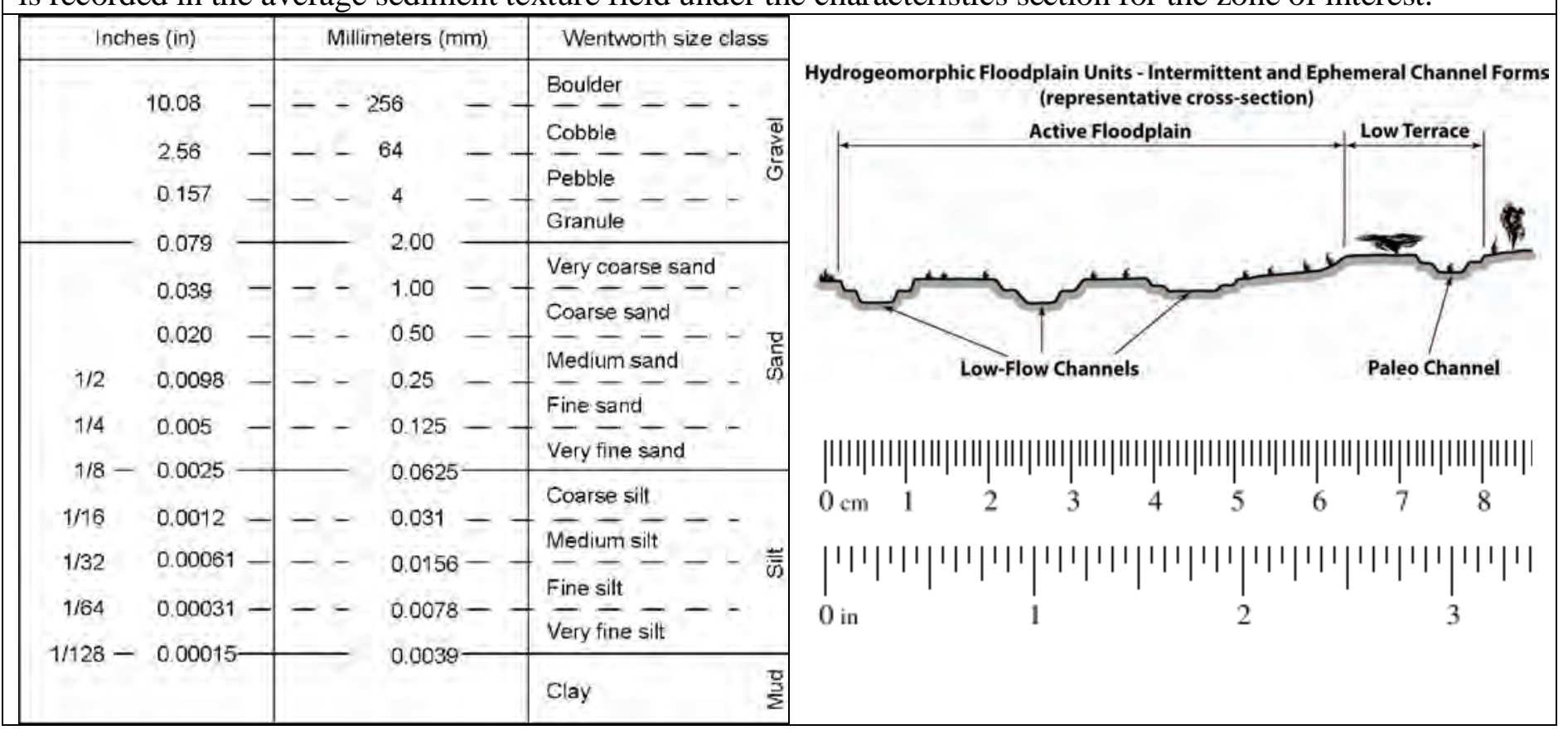




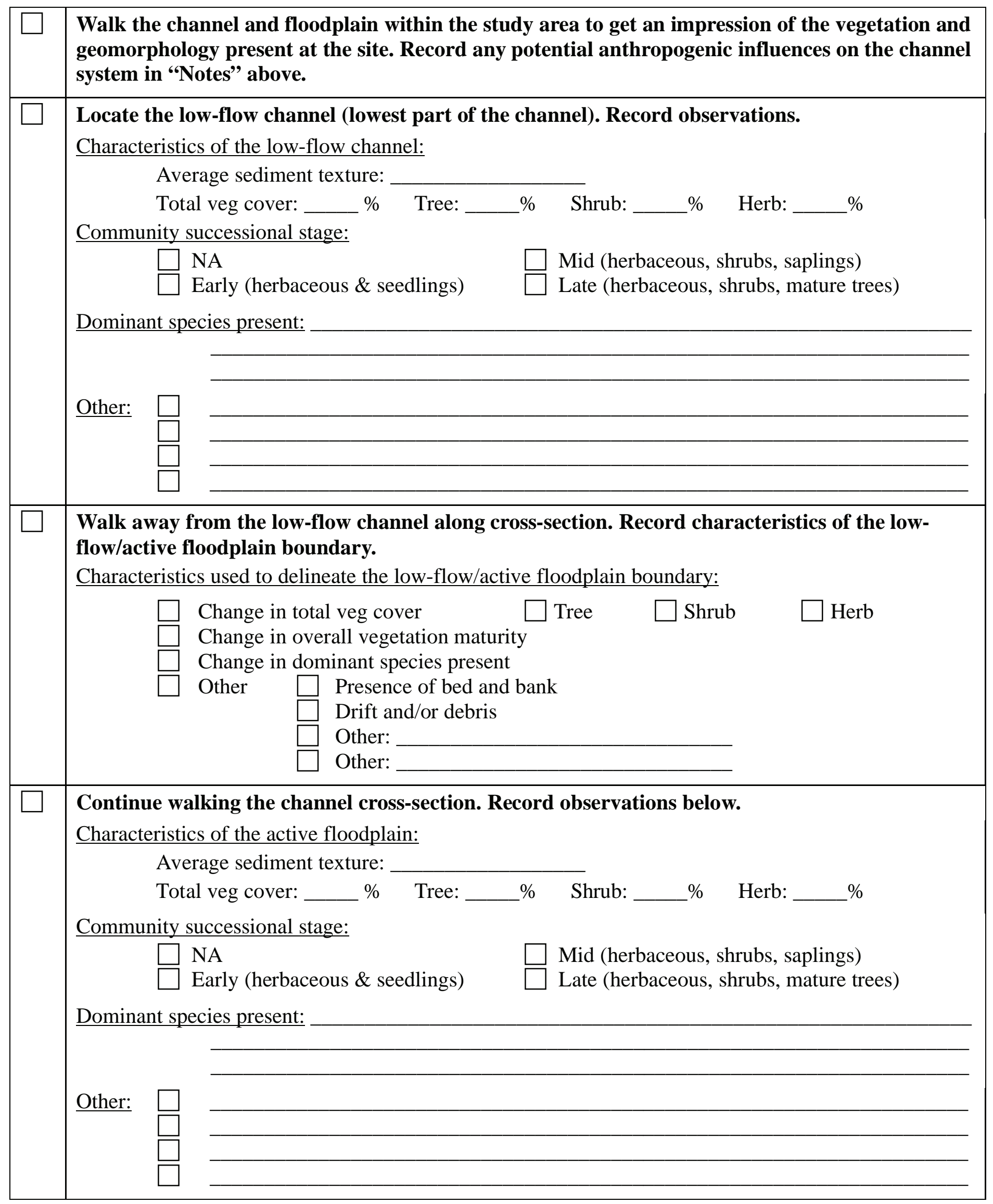




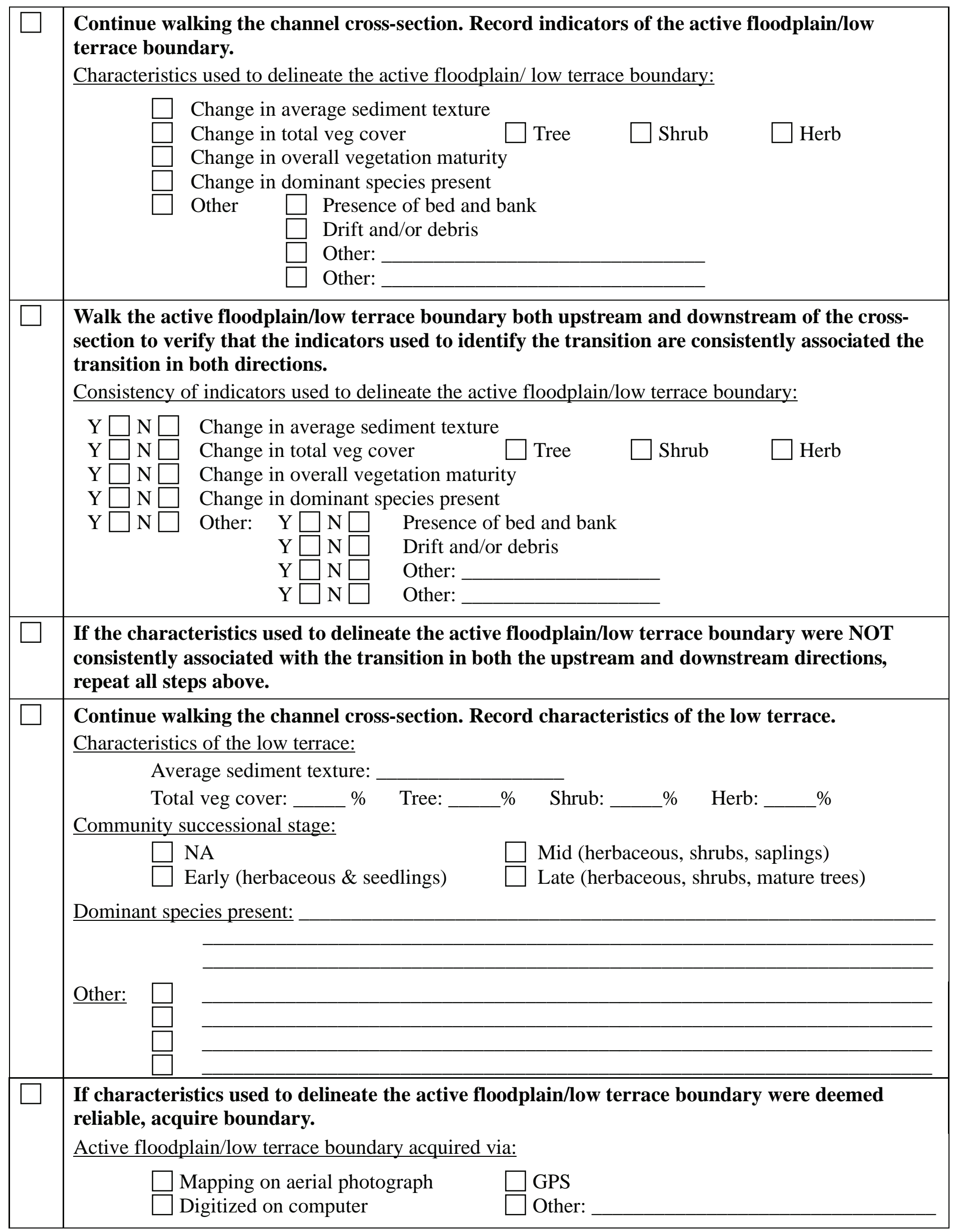




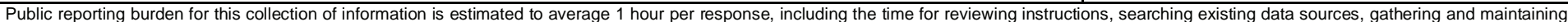

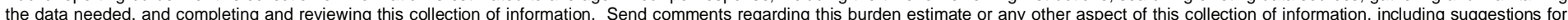

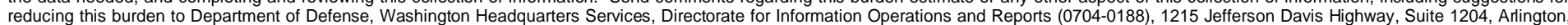

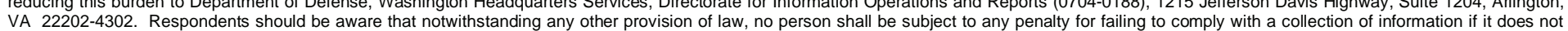
display a currently valid OMB control number. PLEASE DO NOT RETURN YOUR FORM TO THE ABOVE ADDRESS.

\begin{tabular}{l|l} 
1. REPORT DATE (DD-MM-YYYY) & 2. REPORT TYPE \\
August 2008 & Technical Report
\end{tabular}

\section{TITLE AND SUBTITLE}

A Field Guide to the Identification of the Ordinary High Water Mark (OHWM) in the Arid West Region of the Western United States: A Delineation Manual

3. DATES COVERED (From - To)

5a. CONTRACT NUMBER

5b. GRANT NUMBER

5c. PROGRAM ELEMENT NUMBER

\section{AUTHOR(S)}

\section{5d. PROJECT NUMBER}

Robert W. Lichvar and Shawn M. McColley

5e. TASK NUMBER

5f. WORK UNIT NUMBER

\section{PERFORMING ORGANIZATION NAME(S) AND ADDRESS(ES)}

U.S. Army Engineer Research and Development Center

Cold Regions Research and Engineering Laboratory

72 Lyme Road

Hanover, NH 03755-1290

9. SPONSORING / MONITORING AGENCY NAME(S) AND ADDRESS(ES)

8. PERFORMING ORGANIZATION REPORT NUMBER

ERDC/CRREL TR-08-12

10. SPONSOR/MONITOR'S ACRONYM(S)

11. SPONSOR/MONITOR'S REPORT NUMBER(S)

\section{DISTRIBUTION / AVAILABILITY STATEMENT}

Approved for public release; distribution is unlimited.

Available from NTIS, Springfield, Virginia 22161.

\section{SUPPLEMENTARY NOTES}

\section{ABSTRACT}

The Ordinary High Water Mark (OHWM) is an approach for identifying the lateral limits of non-wetland waters. However, determining whether any non-wetland water is a jurisdictional "Water of the United States" (WoUS) involves further assessment in accordance with the regulations, case law, and clarifying guidance. In the Arid West region of the U.S., the most problematic Ordinary High Water (OHW) delineations are associated with the ephemeral/intermittent channel forms that dominate the Arid West landscape. This report presents a method for delineating the lateral extent of the non-wetland waters in the Arid West using stream geomorphology and vegetation response to the dominant stream discharge.

\section{SUBJECT TERMS}

Arid West

Clean Water Act

16. SECURITY CLASSIFICATION OF:

\section{a. REPORT}$$
\mathrm{U}
$$

$\mathrm{U}$
Ordinary High Water

Wetland delineation

Waters of the United States

17. LIMITATION
OF ABSTRACT
$\mathrm{U}$

\begin{tabular}{|c|c|} 
18. NUMBER & \\
OF PAGES & \\
\cline { 2 - 2 } & 1 \\
\hline
\end{tabular}

19a. NAME OF RESPONSIBLE PERSON

19b. TELEPHONE NUMBER (include area code) 